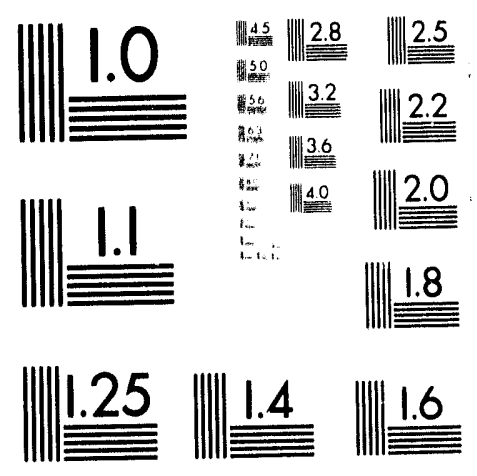



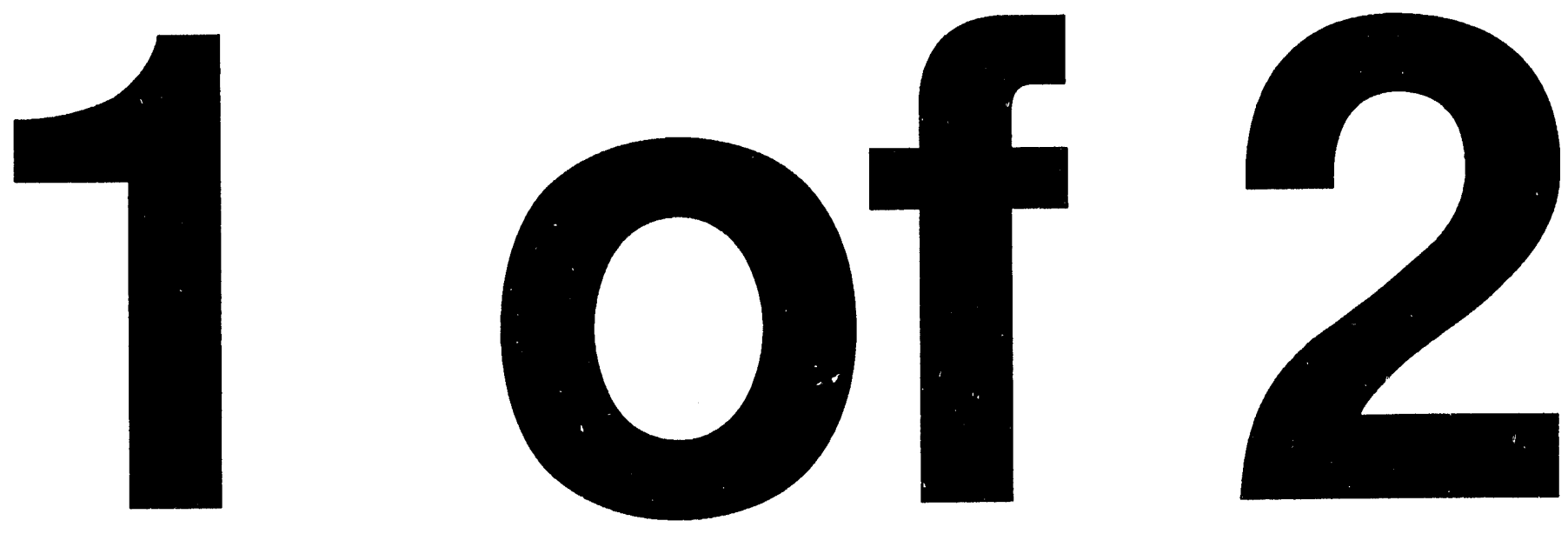


\section{Feasibility Study for the Recycling of Nickel Metal Hydride Electric Vehicle Batteries}

\section{Final Report}

J.C. Sabatini, E.L. Field, I-C. Wu, M.R. Cox, B.M. Barnett, and J.T. Coleman Arthur D. Little, Inc. Cambridge, Massachusetts

NREL technical monitor: David Corbus

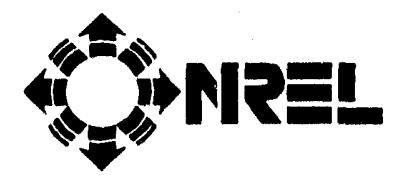

National Renewable Energy Laboratory 1617 Cole Boulevard Golden, Colorado 80401-3393

A national laboratory of the U.S. Department of Energy Operated by Midwest Research Institute for the U.S. Department of Energy under contract No. DE-AC02-83CH10093

Prepared under Subcontract No. TAT-3-13256-01 January 1994 


\section{NOTICE}

NOTICE: This report was prepared as an account of work sponsored by an agency of the United States government. Neither the United States govemment nor any agency thereof, nor any of their employees, makes any warranty, express or implied, or assumes any legal liability or responsibility for the accuracy, completeness, or usefulness of any information, apparatus, product, or process disclosed, or represents that its use would not infringe privately owned rights. Reference herein to any specific commercial product, process, or service by trade name, trademark, manufacturer, or otherwise does not necessanily constitute or imply its endorsement, recommendation, or favoring by the United States government or any agency thereof. The views and opinions of authors expressed herein do not necessarily state or reflect those of the United States govemment or any agency thereof.

Printed in the United States of America

Available from:

National Technical Information Service

U.S. Department of Commerce

5285 Port Royal Road

Springfield, VA 22161

Price: Microfiche A01

Printed Copy A05

Codes are used for pricing all publications. The code is determined by the number of pages in the publication. Intormation pertaining to the pricing codes can be found in the current issue of the following publications which are generally available in most libraries: Energy Research Abstracts (ERA); Goveminent Reports Announcements and Index (GRA and I); Scientific and Technical Abstract Reports (STAR); and publication NTIS-PR-360 available from NTIS at the above address. 
Executive Summary $\ldots \ldots \ldots \ldots \ldots \ldots \ldots \ldots \ldots \ldots \ldots \ldots \ldots \ldots \ldots$

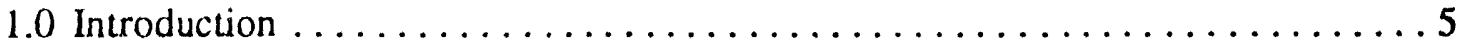

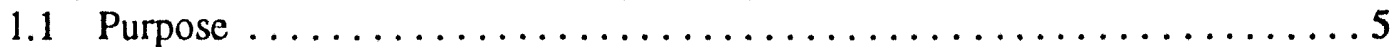

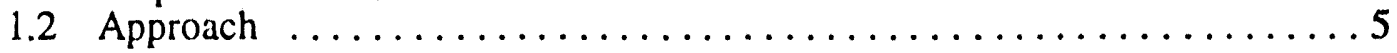

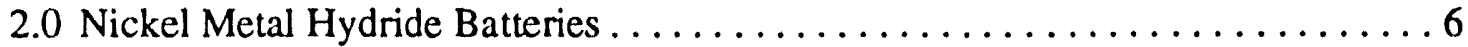

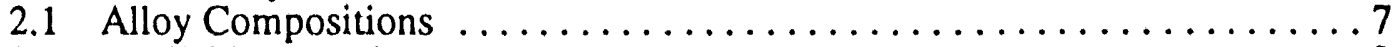

2.2 Available Batteries . . . . . . . . . . . . . . . . . . 9

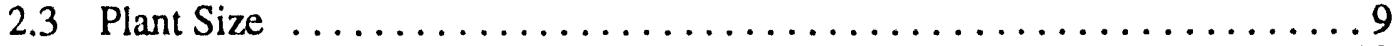

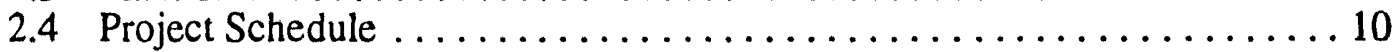

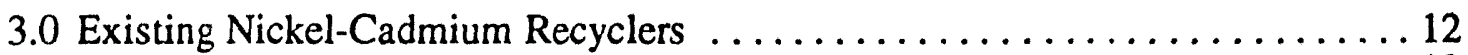

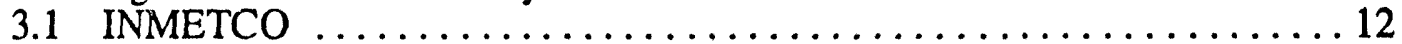

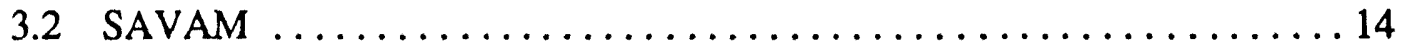

3.3 TNO Nickel-Cadmium Recycling Process $\ldots \ldots \ldots \ldots \ldots \ldots \ldots \ldots$

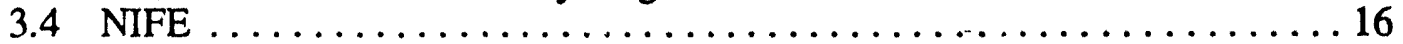

4.0 Processes For Recycling $\mathrm{AB}_{2}$ and $\mathrm{AB}_{5}$ Alloy EV Batteries $\ldots \ldots \ldots \ldots \ldots$

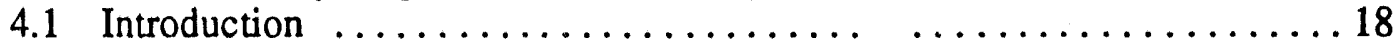

4.2 Chemical Process for $\mathrm{AB}_{2}$ and $\mathrm{AB}_{5}$ Alloy Systems ........... 19

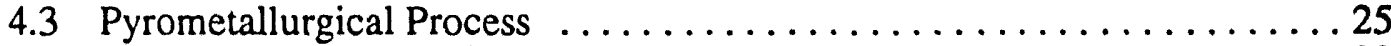

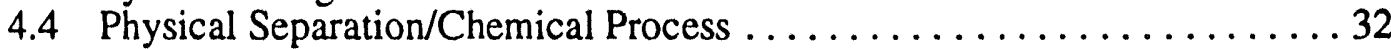

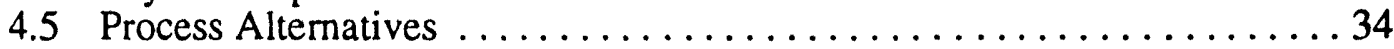

5.0 Capital and Operating Cost Comparisons . . . . . . . . . . . . 37

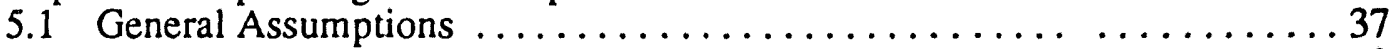

5.2 Capital Investment and Operating Cost for $\mathrm{AB}_{2}$ Processing Plants . . . . . 38

5.3 Capital Investment and Operating Cost for $\mathrm{AB}_{5}$ Processing Plants . . . . 38

5.4 Cost Sensitivities .......................... 55

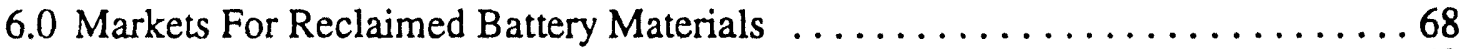

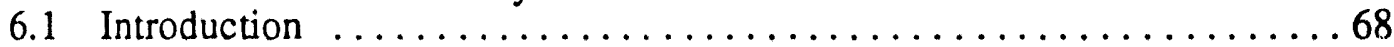

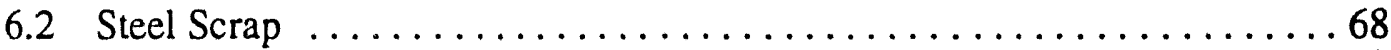

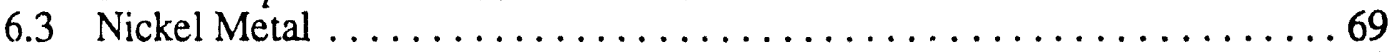

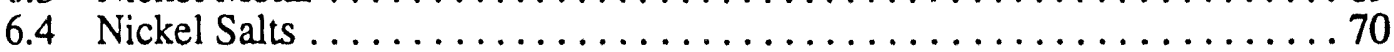

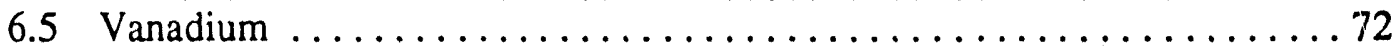

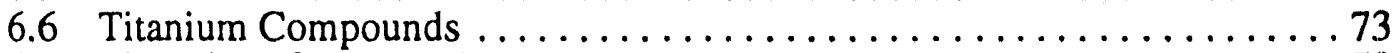

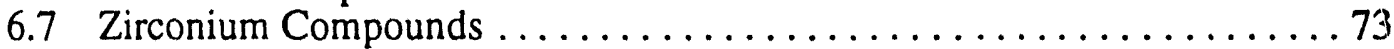

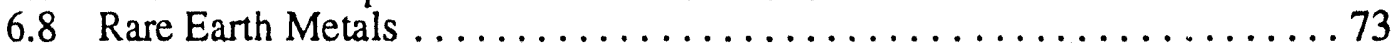

6.9 Potassium Compounds .......................... 74

7.0 Generic Design Criteria .............................. 75

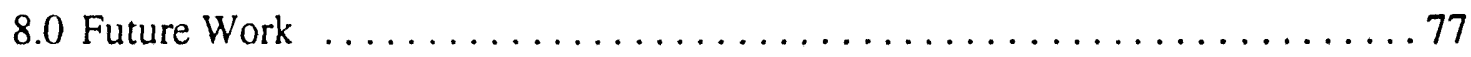

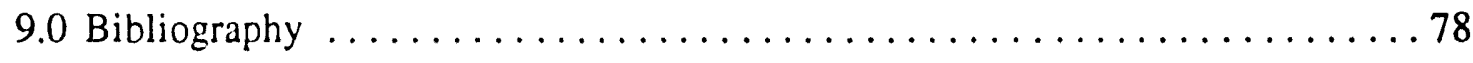

Appendix A Material Balance Calculations For The Individual Processes . . . . 81 
List of Tables

Table E-1: Operating Cost and Capital Investment for Recycling Processes 2

Table E-2: Market for Reclaimed Materials 3

Table 2-1: Hydride Alloy Compositions $\quad 7$

Table 2-2: Weights per $100 \mathrm{~kg}$ of Cells $-\mathrm{AB}_{2}$

Table 2-3: Weights per $100 \mathrm{~kg}$ of Cells $-\mathrm{AB}_{5}$

Table 2-4: EV Battery Population in California 9

Table 5-1: $\mathrm{AB}_{2}$ Alloy Chemical Process Capital Cost 39

Table 5-2: $\mathrm{AB}_{2}$ Alloy Chemical Process Operating Cost Estimate - $\quad 40$

Table 5-3: $\mathrm{AB}_{2}$ Alloy Pyrometallurgical Process Capital Cost Estimate 43

Table 5-4: $\mathrm{AB}_{2}$ Alloy Pyrometallurgical Process Operating Cost Estimate 44

Table 5-5: $\mathrm{AB}_{2}$ Alloy Physical Separation/Chemical Process Capital Cost Estimate 47

Table 5-6: $\mathrm{AB}_{2}$ Alloy Physical Separation/Chemical Process Operating Cost Estimate 48

Table 5-7: $\mathrm{AB}_{5}$ Alloy Chemical Process Carital Cost Estimate 51

Table 5-8: $\mathrm{AB}_{5}$ Alloy Chemical Process Operating Cost Estimate 52

Table 5-9: $\mathrm{AB}_{5}$ Alloy Pyrometallurgical Process Capital Cost Estimate 56

Table 5-10: $\mathrm{AB}_{5}$ Alloy Pyrometallurgical Process Operating Cost Estimate 57

Table 5-11: $\mathrm{AB}_{5}$ Alloy Physical Separation/Chemical Process Capital Cost Estimate 60

Table 5-12: $\mathrm{AB}_{5}$ Alloy Physical Separation/Chemical Process Operating Cost Estimate 61

Table 6-1: U.S. Nickel Consumption by Form Based on Nickel Content 69

Table 6-2: U.S. Nickel Salt Consumption by Use Based on Nickel Content 71 


\section{List of Figures}

Figure 2-1: Cutaway of Typical EV Battery Design 6

Figure 2-2: NiMH EV Battery Recycling Plant Development Schedule 11

Figure 3-1: INMETCO Flow Sheet 12

Figure 3-2: SNAM Process $\quad 15$

Figure 3-3:TNO Process for Ni-Cd Cells 17

Figure 4-1: $\mathrm{AB}_{2}$ and $\mathrm{AB}_{5} 5$ Alloy Chemical Process 20

Figure 4-2: $\mathrm{AB}_{2}$ Alloy Pyrometallurgical Process 27

Figure 4-3: $\mathrm{AB}_{5}$ Alloy Pyrometallurgical Process 30

Figure 4-4: $\mathrm{AB}_{2}$ and $\mathrm{AB}_{5}$ Alloy Physical Separation/Chemical Process 35

Figure 5-1: Impact of By-Product Credits on $\mathrm{AB}_{2}$ Process Operating Cost 64

Figure 5-2: Impact of Electricity Cost on $\mathrm{AB}_{2}$ Process Operating Cost 64

Figure 5-3: Impact of Capital Investment on $\mathrm{AB}_{2}$ Process Operating Cost 65

Figure 5-4: Impact of Interest Rate on $\mathrm{AB}_{2}$ Process Operating Cost 65

Figure 5-5: Impact of By-Product Credits on $\mathrm{AB}_{5}$ Process Operating Cost 66

Figure 5-6: Impact of Electricity Cost on $\mathrm{AB}_{5}$ Process Operating Cost 66

Figure 5-7: Impact of Capital Investment on $\mathrm{AB}_{5}$ Process Operating Cost 67

Figure 5-8: Impact of Interest Rate on $\mathrm{AB}_{5}$ Process Operating Cost 67

Figure 6-1: Historic \#1 Heavy Melting Steel Scrap Price 68

Figure 6-2: Historic Nickel Cathode Price $\quad 70$

Figure 6-3: Historic Vanadium Price $\quad 72$ 


\section{Executive Summary}

Arthur D. Little conducted a feasibility study of possible recycling processes for nickel metal hydride electric vehicle (EV) batteries. Processes were cvaluated for recycling of two example compositions of $A B_{2}$ and $A B_{5}$ systems. The actual battery compositions were estimated based on published compositions of battery alloys. Actual compositions of current EV designs were requested from representatives of major EV battery developers, but no information was released. Three possible recycling processes were evaluated to determine possible routes for recovering battery materials. The processes were based on similar processes used commercially, currently, or in the past, to recover the major components found within nickelcadmium batteries or for the recovery of nickel from waste materials. The processes focus on recovering the major constituent materials in the nickel metal hydride batteries, nickel and iron. $V$ anadium recovery from the $A B_{2}$ system and rare-earth metals recovery from the $A B_{5}$ system were investigated. In addition, polypropylene is also recovered in each of the processes.

Cost estimates were prepared for capital equipment required for a plant processing 30,000 metric tons of electric vehicle batteries per year. Additionally, operating cost estimates were developed for each of the processes. These cost estimates are based on preliminary design calculations for the process equipment and on typical process yields from similar processes.

Each of the three processes utilize common technology for the dismantling of the battery into various major streams (e.g., cases, electrodes, electrolyte) and each of the streams are treated separately. Common recycling and materials handling equipment are used for the initial process steps including cutting equipment, shredders, screens, magnetic separators, and similar equipment.

The first process, based upon hydrochloric acid leaching of battery materials, leaches the battery powders, primarily nickel hydroxide and hydride alloys. The materials are leached in hot acid $\left(90^{\circ} \mathrm{C}\right)$. The pregnant leach liquor is neutralized to $\mathrm{pH} 3$ or 4 to precipitate all elements except nickel (and cobalt, if available). The neutralized liquor is sent to an electrowinning plant to recover nickel metal. Additionally, the precipitates are dewatered and may potentially be sold to producers of special ferroalloys or for other similar applications. The main products from this process are nickel-iron scrap, steel scrap, polypropylene, and nickel metal.

The second process alternative is to produce ferroalloys utilizing pyrometallurgical processes. The battery electrodes and powders are smelted in an electric air furnace to produce a crude ferronickel product and a slag rich in the hydride alloy elements. The crude ferronickel product is refined with oxygen in a converter furnace to produce a reasonably high purity ferronickel product which is useful to the steel industry. The furnace slag is sent to a second electric arc furnace and is smelted with aluminum to produce ferrovanadium in the case of the $\mathrm{AB}_{2}$ product. This ferrovanadium will contain some nickel and chromium as well, and will have niche applications in the steel industry. The slag from the $\mathrm{AB}_{5}$ alloy processing furnace is too low in quantity to justify the investment in processing within the plant. However, the rareearth processors may have interest in the material. The main products are nickel-iron scrap, steel scrap, ferrovanadium (in the case of $\mathrm{AB}_{2}$ ), enriched rare earth slag (in the case of $\mathrm{AB}_{5}$ ), and low-grade furnace slag.

The third process borrows from the first process in that it combines chemical leaching and electrowinning, but it does not treat the hydride alloy; only the nickel hydroxides are processed chemically. The process takes advantage of the large physical size of the batteries. The battery electrodes and electrolyte are removed from the battery case. The electrodes bundles are 
separated using mechanical cutting equipment and manually separated into three fractions, the hydride alloy electrode, the nickel hydroxide electrode, and the separators. The separated electrodes are then processed independently.

The nickel hydroxide electrodes are shredded and screened. The larger nickel chips are separated magnetically from the nickel hydroxide. The nickel hydroxide is leached with hydrochloric acid, neutralized to precipitate any iron impurities, and then nickel is electrowon.

The nickel metal hydride electrode is also shredded in a different circuit and the iron is separated magnetically. The remaining hydride alloy is washed, dried, and returned to the hydride alloy producer for reuse. It is expected that the hydride alloy-material will be partially oxidized, but is expected to be useful as a partial feed to produce new hydride alloys. A hydrogen annealing step may be required to remove surface oxidation before remelting.

All three processes were evaluated to determine the total capital investment and to develop estimates of the process operating costs, value of the reclaimed products, and developed estimated operating revenue. The results of those estimates are shown in Table E-1.

Table E-1. Operating Cost and Capital Investment for Recycling Processes

\begin{tabular}{|c|c|c|c|}
\hline Proces 8 & $\begin{array}{c}\text { Capital Cost } \\
\text { (SMillion) }\end{array}$ & $\begin{array}{l}\text { Operating Revenue } \\
\text { (Cost) S/EV Battery }\end{array}$ & $\begin{array}{c}\text { Operating Revenue } \\
\text { (Cost) } \mathrm{S} / \mathrm{kWh}\end{array}$ \\
\hline \multicolumn{4}{|l|}{$A_{3}$} \\
\hline Chemical & 42.6 & (12.59) & $(0.16)$ \\
\hline Pyrometallurgical & 46.5 & 195.73 & 2.45 \\
\hline Physical Separation/Chemical & 23.3 & 480.74 & 6.01 \\
\hline \multicolumn{4}{|l|}{$A B_{5}$} \\
\hline Chemical & 35.9 & 246.95 & 3.09 \\
\hline Pyrometallurgical & 34.8 & 108.27 & 1.35 \\
\hline Physical Separation/Chemical & 23.3 & 434.34 & 5.43 \\
\hline
\end{tabular}

\section{*Basis $80 \mathrm{Wh} / \mathrm{Kg}$}

From the results of the economic analysis, the physical separation/chemical process would generate the greatest revenue. The pyrometallurgical process provides greater revenue than the chemical process in the case of $\mathrm{AB}_{2}$ batteries. For the $A B_{5}$ batteries, the chemical process generates greater revenue than the pyrometallurgical process. The chemical process in the case of the $\mathrm{AB}_{2}$ systems does not provide the minimum 30 percent return-on-investment which would be necessary for most investments. 
A market evaluation was conducted to develop estimates of the value of reclaimed materials. Evaluations of the steel scrap, nickel, ferronickel, and nickel salt markets were done, since nickel and iron are the two largest quantity materials available in nickel metal hydride batteries. In addition, markets for the minor elements were also reviewed. It appears that vanadium from $\mathrm{AB}_{2}$ alloys and misch-metal oxide or salts could be recovered from the batteries. The U.S. consumption of each of the major possible reclaimed materials is shown in Table E-2. Clearly, the nickel and iron scrap will have little impact on the overall market, but the other candidate materials will have a much greater impact on the market conditions.

Table E-2. Market for Reclaimed Materials

\begin{tabular}{|c|c|c|c|c|c|}
\hline Material & $\begin{array}{c}\text { U.S. } \\
\text { Consumption } \\
\text { Metric Tons } \\
(1992) \\
\end{array}$ & $\begin{array}{c}\text { Generated } \\
\text { from } \mathrm{AB}_{2} \text { NIMH } \\
\text { Cells Metric } \\
\text { Tons } \\
\end{array}$ & $\begin{array}{c}\begin{array}{c}\% \text { of Total } \\
\text { U.S. }\end{array} \\
\text { Consumption }\end{array}$ & $\begin{array}{c}\text { Generated } \\
\text { from AB NiMH } \\
\text { Cells Metric } \\
\text { Tons } \\
\end{array}$ & $\begin{array}{c}\% \text { of Total } \\
\text { U.S. } \\
\text { Consumption }\end{array}$ \\
\hline Steol Scrap & $64,300,000$ & 8,800 & 0.01 & 8,800 & 0.01 \\
\hline Nickel Metal & 145,000 & 2,700 & 1.9 & 3,900 & 2.7 \\
\hline Ferronickel & 15,000 & 5,900 & 39.3 & 6,700 & 44.7 \\
\hline Nickel Salts" & about 6.000 & 4,300 & 71.7 & 6,300 & 105 \\
\hline Ferrovanadium & 3.800 & 1.700 & 44.7 & $\dot{-}$ & - \\
\hline Mixed Rare Earth Oxides & 15,700 & $\dot{-}$ & - & 1,600 & 10.2 \\
\hline
\end{tabular}

*Basis nickel chloride

Following are the details of the process and market evaluation for the reclamation of $\mathrm{AB}_{2}$ and $\mathrm{AB}_{5}$ nickel metal hydride batteries for electric vehicle applications. 


\section{Acknowledgment}

The authors would like to express sincere appreciation to the National Renewable Energy Laboratory for their cooperation and support of this program.

Joseph C. Sabatini Program Manager

Edwin L. Field

I-Ching Wu

Mark R. Cox

Brian M. Barnett

Joann T. Coleman 


\subsection{Introduction}

Arthur D. Little, Inc., conducted a technical and economic feasibility study of the recycling of nickel metal hydride batteries for use in future electric vehicles. The study focused on three possible process scenarios: chemical, pyrometallurgical, and physical separation and selective chemical processing routes. The study was conducted under subcontract number TAT-313256-01 for the National Renewable Energy Laboratory (NREL) Division of the Midwest Research Institute.

\subsection{Purpose}

The purpose of the feasibility study was to develop capital and operating cost estimates for likely recycling processes for nickel metal hydride batteries, which would be used in electric vehicles. The feasibility study evaluated possible recycling options for EV battery materials, and process costs for recycling were estimated. Currently, no commercial process is known or available for recycling nickel metal hydride batteries, nor is there experience in the large-scale use of nickel metal hydride batteries in electric vehicles. Because of the limitations on information available on nickel metal hydride battery chemistries and recycling processes, much of the analyses within this study was made by personnel skilled in battery engineering and chemical/metallurgical process engineering. Only publicly available information was used in the preparation of this study.

\subsection{Approach}

The study focussed on the recycling of two basic nickel metal hydride battery chemistries which are distinguished based on the use of two different hydride alloys. These alloys are a rare earth misch metal $\mathrm{AB}_{5}$ composition and a vanadium-rich refractory metal alloy, $\mathrm{AB}_{2}$. These alloys were chosen as representative of possible alloys which could be used in electric vehicle EV systems. Inquiries were made to several major nickel metal hydride battery developers and through DOE contacts within the United States Advanced Battery Consortium (USABC) to obtain the exact compositions of the batteries, but we were informed that these compositions were to be considered proprietary and that the information could not be released. Therefore, Arthur D. Little developed estimates of possible compositions based on available literature and made assumptions as to the possible alloy composition, the construction of the battery cells, and the overall composition of the battery.

Processes which are currently available for recycling nickel cadmium batteries were reviewed for possible application for recycling of EV nickel metal hydride batteries. Conceptual processes were developed which could recycle EV battery materials. These processes were based on known metallurgical and chemical engineering principles and processes, and no individual unit operation in any of the processes requires specific reactor technologies for recycling batteries. Rather, all equipment would be based on "off-the-shelf" technology. However, some of the equipment for the processes may have to be somewhat modified to be suitable for handling EV nickel metal hydride batteries.

Cost estimates were developed based upon vendor quotations, equipment cost curves, and equipment sizing factors. Operating costs were estimated based upon material balances developed for the individual processes and yield assumptions for similar metallurgical and chemical processes.

The market for battery by-products was reviewed, and key companies operating within each sector were contacted to ascertain their interest in possible reclaimed materials. 


\subsection{Nickel Metal Hydride Batteries}

Two basic nickel metal hydride systems were evaluated for recycling, a vanadium-rich refractory metal $A B_{2}$ alloy and a rare-earth misch metal $A B_{5}$ alloy. The hydride alloy (negative) electrode was assumed to be prepared by pressing the active metal powders into a nickel-plated steel sheet. The counter electrode was assumed to be nickeloxy-hydroxide (NiOOH) powder which had been pressed into a nickel-foam substrate. The separators were assumed to be polypropylene sheets. The battery electrolyte was assumed to be 30 percent potassium hydroxide solution with approximately one percent of the battery weight to be additives, such as leveling agents, and inert unrecoverable materials. The battery case was assumed to be nickel-plated steel. A schematic of the battery design is shown in Figure 2-1. We expect the battery has a construction similar to other large prismatic cells.

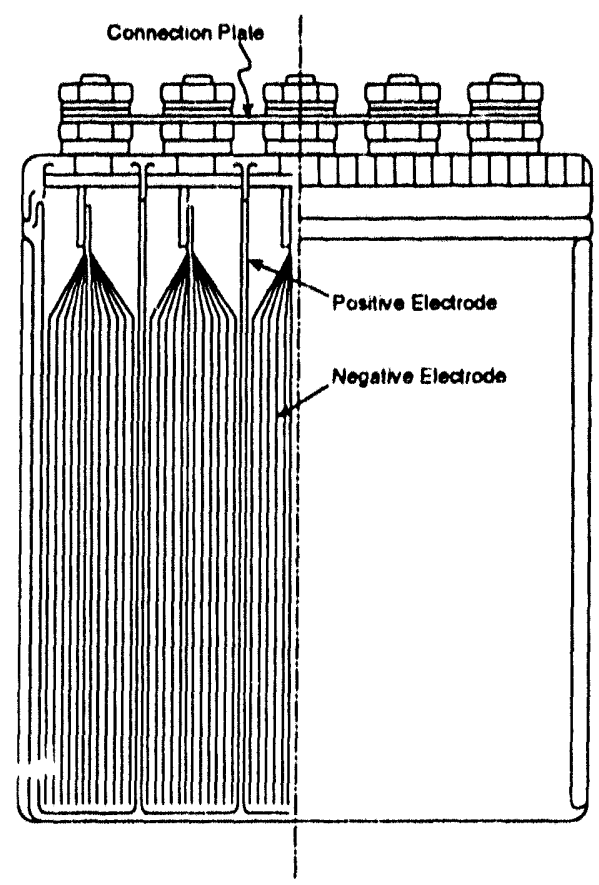

Figure 2-1: Cutaway of typical EV Battery Design

Source: Matsumoto, et al. 


\subsection{Alloy Compositions}

The $\mathrm{AB}_{2}$ and $\mathrm{AB}_{5}$ alloy compositions are shown in Table 2-1.

Requests were made to leading $\mathrm{AB}_{2}$ and $\mathrm{AB}_{5} \mathrm{EV}$ Battery developers for details of the alloy compositions. These data were not released for the study. Therefore, some of the assumptions made for the alloy compositions were based upon patents (Fetcenko, 1990, 1991, Ovshinsky, 1985, Reichman 1987), publications (Lyman 1993), conversations with industry participants, and some assumptions were developed by Arthur D. Little personnel.

Table 2-1. Hydride Alloy Compositions (weight percent)

\begin{tabular}{|l|c|c|}
\hline Element & $\mathbf{A B}_{\mathbf{2}}$ & $\mathbf{A B}_{\mathbf{5}}$ \\
\hline Nickel & 13.9 & 48.8 \\
\hline Vanadiurn & 47.3 & \\
\hline Zirconium & 16.7 & \\
\hline Titanium & 5.3 & \\
\hline Chromium & 14.3 & 1.9 \\
\hline Aluminum & 2.5 & 21.4 \\
\hline Lanthanum & & 1.3 \\
\hline Cerium & & 9.3 \\
\hline Praseodymium & & 1.0 \\
\hline Neodymium & & 11.1 \\
\hline Cobalt & & 5.2 \\
\hline Manganese & & \\
\hline
\end{tabular}

The compositions of the $\mathrm{AB}_{2}$ system was based upon data available from Ovonic Battery Company and Energy Conversion Devices patents. A composition which was high in vanadium content was chosen to provide a specific example of the capability to recover additional elements beyond nickel and iron, in this case vanadium. In the case of the $\mathrm{AB}_{5}$ system, the composition of the bydride alloy was obtained from several sources including the Bureau of Mines, Teledyne Wah Chang, and several reports of the Saft composition. None of these compositions should be accepted as the leading compositions of new nickel metal hydride cells, because conformation from the battery developers could not be obtained.

Assumptions were made to develop an estimate of overall battery composition for each battery type. The assumptions relate to the mass of the individual components, composition of the individual components, and the overall composition of each cell type.

The active metal alloy electrodes and contact bar (current collector) were assumed to be 30 percent of the battery weight, the positive nickelic hydroxide electrode was assumed to be 25 percent of the battery weight, the battery case was assumed to be 30 percent of the battery weight, the separators and seals were assumed to be five percent of the battery weight, and the electrolyte was assumed to be 10 percent of the battery weight. The values were based on extrapolations of publicly available data for cylindrical cells to prismatic cell designs.

The overall compositions of the batteries are shown in Tables 2-2 and 2-3. 
Table 2-2. Weights per $100 \mathrm{Kg}$ of Cells $-\mathrm{AB}_{2}$

\begin{tabular}{|l|r|r|r|r|r|}
\hline \multicolumn{1}{|c|}{ Material } & $\begin{array}{r}\text { Active } \\
\text { Metal } \\
\text { Electrode }\end{array}$ & $\begin{array}{r}\text { Ni(OH)2 } \\
\text { Electrode }\end{array}$ & Case & Other & Total \\
\hline Nickel & 2.59 & 20.42 & 1.00 & & 24.01 \\
\hline Iron & 14.50 & & 29.00 & & 43.50 \\
\hline Vanadium & 7.11 & & & & 7.11 \\
\hline Zirconium & 2.50 & & & & 2.50 \\
\hline Titanium & 0.79 & & & & 0.79 \\
\hline Chromium & 2.14 & & & & 2.14 \\
\hline Aluminum & 0.37 & & & & 0.37 \\
\hline Oxygen & & 4.31 & & & 4.31 \\
\hline Hydrogen & & 0.27 & & & 0.27 \\
\hline Potassium Hydroxide & & & & 3.00 & 3.00 \\
\hline Water & & & & 6.00 & 6.00 \\
\hline Leveling agents & & & & 1.00 & 1.00 \\
\hline Polypropylene & & & & 5.00 & 5.00 \\
\hline Total & 30.00 & 25.00 & 30.00 & 15.00 & 100.00 \\
\hline
\end{tabular}

Table 2-3. Weights per $100 \mathrm{Kg}$ of Cells $-\mathrm{AB}_{5}$

\begin{tabular}{|l|r|r|r|r|r|}
\hline Material & $\begin{array}{c}\text { Active Meta! } \\
\text { Electrode }\end{array}$ & $\begin{array}{r}\text { Ni(OH) } \\
\text { Electrode }\end{array}$ & Case & Other & Total \\
\hline Nickel & 7.80 & 20.42 & 1.00 & & 29.22 \\
\hline Iron & 14.50 & & 29.00 & & 43.50 \\
\hline Lanthanum & 3.21 & & & & 3.21 \\
\hline Cerium & 0.20 & & & & 0.20 \\
\hline Praesodymium & 1.40 & & & & 1.40 \\
\hline Neodymium & 0.15 & & & & 0.15 \\
\hline Cobalt & 1.67 & & & & 1.67 \\
\hline Manganese & 0.78 & & & & 0.78 \\
\hline Aluminum & 0.29 & & & & 0.29 \\
\hline Oxygen & & 4.31 & & & 4.31 \\
\hline Hydrogen & & 0.27 & & & 0.27 \\
\hline Potassium hydroxide & & & & 3.00 & 3.00 \\
\hline Water & & & & 6.00 & 6.00 \\
\hline Leveling agents & & & & 1.00 & 1.00 \\
\hline Polypropylene & & & & 5.00 & 5.00 \\
\hline Total & 30.00 & 25.00 & 30.00 & 15.00 & 100.00 \\
\hline
\end{tabular}




\subsection{Available Batteries}

According to the California Low Emission Vehicle Program, in 1998 two percent of the vehicles sold in California will be required to be zero emission vehicles. The number of zero emission vehicles increases to 10 percent by 2003 . If we assume 50 percent of all zero emissions vehicles sold in California are EVs with nickel metal hydride batteries, then the total population of EVs in California will be approximately 175,000 units by 2003 . To calculate the available EV batteries for recycling, it was assumed that an EV battery has a useful life of five years, between 1998 and 2002, and seven years from 2002 onward (the increase in battery lifetime would be reflective of technology development), and weighs 325 kilograms. The weight of the battery was based on an $75-80 \mathrm{Wh} / \mathrm{kg}$ specific energy requirement and a $25 \mathrm{~kW}$ total energy requirement per battery.

Therefore, the total weight of batteries available annually for recycling in California will be 28,500 metric tons by 2007. The possible EV population is shown in Table 2-4.

Table 2-4. EV Battery Population in California

\begin{tabular}{|r|r|r|r|r|r|}
\hline Year & $\begin{array}{r}\text { Sales } \\
\text { Target }\end{array}$ & $\begin{array}{c}\text { New } \\
\text { Pollution-Free } \\
\text { Vehicles }\end{array}$ & $\begin{array}{c}\text { Return* } \\
\text { Batteries }\end{array}$ & $\begin{array}{c}\text { Weight of } \\
\text { Returns } \\
\text { (Metric Tons) }\end{array}$ & $\begin{array}{c}\text { Cumulative } \\
\text { Returns } \\
\text { (Metric Tons) }\end{array}$ \\
\hline 1998 & $2 \%$ & 35,000 & 0 & 0 & 0 \\
\hline 1999 & $2 \%$ & 35,000 & 0 & 0 & 0 \\
\hline 2000 & $2 \%$ & 35,000 & 0 & 0 & 0 \\
\hline 2001 & $5 \%$ & 87,500 & 0 & 0 & 5,700 \\
\hline 2002 & $5 \%$ & 87,500 & 17,500 & 5,700 & 11,400 \\
\hline 2003 & $10 \%$ & 175,000 & 17,500 & 5,700 & 17,100 \\
\hline 2004 & $10 \%$ & 175,000 & 17,500 & 5,700 & 31,300 \\
\hline 2005 & $10 \%$ & 175,000 & 43,750 & 14,200 & 45,500 \\
\hline 2006 & $10 \%$ & 175,000 & 43,750 & 14,200 & 74,000 \\
\hline 2007 & $10 \%$ & 175,000 & 87,500 & 28,500 & 102,500 \\
\hline 2008 & $10 \%$ & 175,000 & 87,500 & 28,500 & 1 \\
\hline
\end{tabular}

*Note: Returned batteries equal 50 percent of pollution-free vehicle population Basis of 1.75 million new vehicles per year.

\subsection{Plant Size}

The process cost estimates were based upon a plant placed in southeastern California which could process all of the state's EV battery discards. Because the only states planning pollution-free vehicle legislation are Califormia and several states in the Northeast, it is likely that the cost to transport the EV batteries generated in the Northeast to California or vice-versa would be excessive, and it is likely that two regionally dedicated plants would be built, one in California and one in the Northeast. In addition, it is difficult to believe that California will export the discarded batteries outside of the state. Therefore, the process cost estimates are for a California-based plant with an operating capacity of 30,000 metric tons per year of discarded EV batteries. Based upon the discard rate and the need to reach full production at any plant in a short time period, we assume that full production at the plant would begin in 2005. 
Modular construction would be an option during initiation of recycling until a reasonable economic size is reached. Start-up would initiate when it is economically advantageous. Additionally, because of the anticipated start-up problems when utilizing a new process, anticipated time to reach full production could take six months. However, for simplicity, given the nature of the pre-feasibility study, the assumption that the plant would start-up at full capacity was used.

\subsection{Project Schedule}

Based upon similar experiences in obtaining operating permits in the United States for battery recycling plants and similar reclamation facilities, it is anticipated that it will require approximately two to three years to obtain the necessary permits to begin construction of a recycling plant. The required lead time to construct the plant would be approximately two years before the anticipated startup date. A possible schedule for development to startup of the battery recycling plant is shown in Figure 2-2.

The selection of the site and the initiation of the environmental permit application procedure must begin early hecause:

- the processes for recycling nickel metal hydride batteries are not proven, requiring significant process development

- there is long-term uncertainty regarding the final battery system

- there is a need to overcome the Not-In-My-Back-Yard (NIMBY) syndrome. 


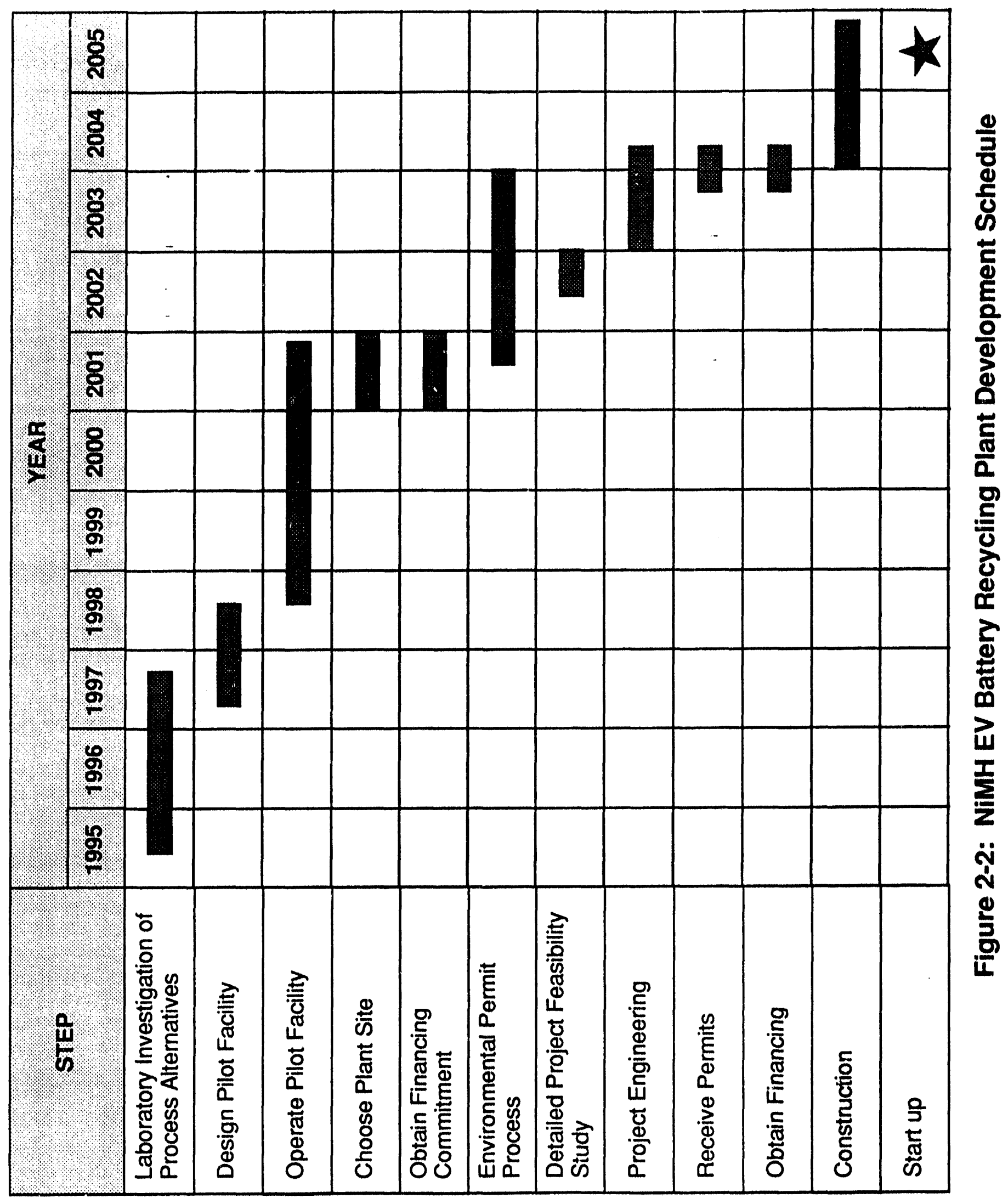




\subsection{Existing Nickel-Cadmium Recyclers}

Recently, there have been discussions which focused on the ability to utilize nickel-cadmium battery recycling plants for the recycling of nickel metal hydride batteries. In this section, current nickel-cadmium recycling processes are discussed and estimates of their recycling costs are presented. The processes reviewed include INMETCO, SNAM/SAVAM, TNO, and NIFE.

Based on a review of the current processes, it is unlikely that any of these plants could handle significant quantities of nickel metal hydride cells. The plants are not designed to recover the hydride alloy components, and they are in limited capacity. Each process would need to be modified to process nickel metal hydride cells, because the entire cadmium treatment circuit in each of these processes would be unnecessary. In addition, the refractory metals and rare earths would significantly affect the process chemistry.

Nevertheless, the processes are discussed below since some of the process units used in the nickel metal hydride recycling processes borrow technology from nickel-cadmium recycling plants.

\subsection{INMETCO}

The International Metals Reclamation Company (INMETCO) is operated as a waste treatment facility for nickel-and chromiurn-bearing wastes. The facility, located in Ellwood City, Pennsylvania (near Pittsburgh) was built in the late 1970s by INCC, the current operator of the facility.

INMETCO processes waste products from the production of stainless steels, including pickling acids, sludges, grindings, mill scale, and electroplating wastes. INMETCO processed approximately 56,000 metric tons of waste in 1992, which included approximately 1,200 metric tons of nickel-cadmium and nickel-iron batteries. They processed both large industrial and small-sealed cells (Onuska, 1993).

INMETCO treats various steel-making wastes that contain nickel, chromium, and iron by a two-step thermal process. All wastes are reduced in size and mixed with carbon and fluxes. These blended materials are pelletized. The pellets and other wastes are introduced into the rotary hearth furnace, where they are partially reduced to metallic constituents and oxides. This reduced material is fed to an electric furnace for smelting into an iron-nickel-chrome alloy. The metal is cast into pigs, and the slag is tapped from the furnace, cooled, and granulated. The company sells the alloy to stainless steel producers, and the slag is sold as road building materials and railroad ballast. The process flow sheet is shown in Figure 3-1.

Nickel-cadmium and nickel-iron batteries are treated separately from the main feed stream. The electrolyte is drained from the batteries which are then shredded. The shredded batteries are collected in tote bins for subsequent feed into the rotary hearth furnace. The batteries then proceed through the process with the other wastes. The cadmium materials are fumed from the rotary hearth furnace, collected in a wet scrubber, and recovered as a filter cake. The dusts recovered from the electric furnace contain zinc and cadmium. The cadmium- and zinccontaining materials are processed by another company.

INMETCO's current charge for industrial nickel-cadmium batteries is between $\$ 175$ and $\$ 575$ per metric ton depending upon battery type and quality (Schweers, 1993). 


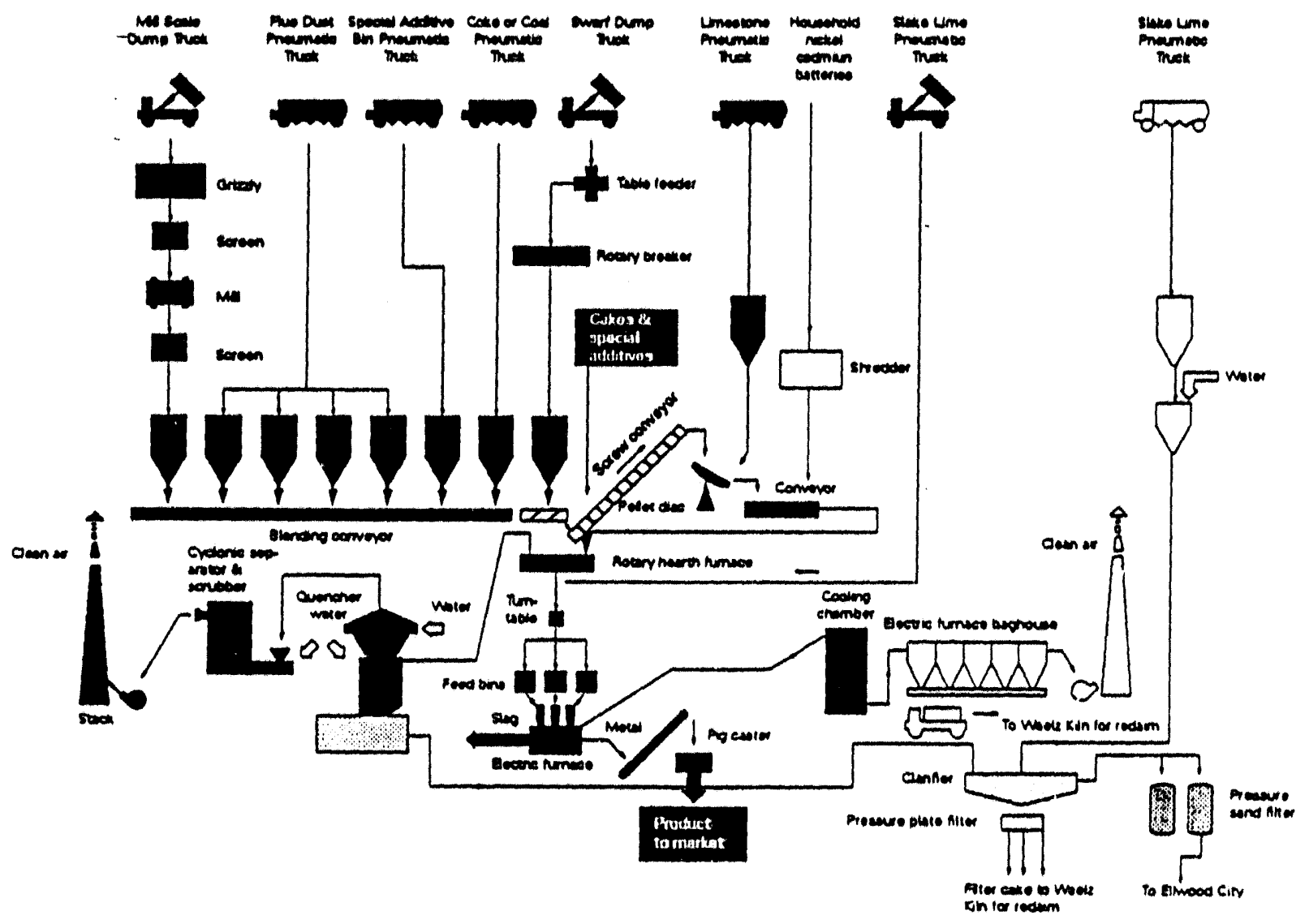

Figure 3-1: INMETCO Flow Sheet 


\subsection{Societe Aveyronnaise de Valorisation des Metaux (SAVAM)}

The SAVAM plant operates in France to recover nickel and cadmium from spent industrial nickel-cadmium cells. The company has a sister plant which processes both large industrial accumulators and small-sealed nickel-cadmium cells (SNAM). The Savam plant began operating in 1988 and is located in Viviez, France. The current processing capacity of SAVAM is 2,200 metric tons of large industrial batteries, while the SNAM plant has a capacity of 1,000 metric tons per year.

The SNAM plant has a production capacity of approximately 200 to 250 metric tons of cadmium, and the SAVAM plant a capacity of 400 to 450 metric tons of cadmium. The combined ferronickel production of the two plants is 1,500 metric tons, with SAVAM producing about 1000 metric tons and SNAM producing approximately 500 metric tons.

The process flow sheet for the SNAM process is shown in Figure 3-2. The SNAM process begins with an initial pyrolysis and distillation step to volatilize the cadmium from the cells. This volatilization is conducted in a batch distillation furnace with the cadmium stream being collected in a vessel from which the cadmium can be further distilled to produce the required level of purity. The cadmium is then cast into sticks or other shapes for subsequent sale to the market. The material that remains in the pyrolysis furnace is mainly nickel, steel, and carbon char. This material is removed from the pyrolysis furnace and sent to the ferronickel furnace for subsequent smelting into ferronickel. Slag-forming fluxes are added to the feed to remove impurities from the ferronickel and, subsequently, ferronickel is cast into pigs or sows for sale to the market (David, J., 1989).

The SNAM and SAVAM processes can treat only spent nickel-cadmium cells. The company has been evaluating the recycling of nickel metal hydride cells, but would have to change the process to treat them. The batteries would not be treated within the cadmium furnace, but would be smelted to produce ferronickel (David, J., 1992).

The current cost of nickel-cadmium battery recycling at SNAM is estimated at $\$ 220 /$ metric ton of nickel-cadmium EV batteries (David, 1993).

\subsection{TNO Nickel-Cadmium Recycling Process}

TNO, a non profit research organization in the Netherlands, developed a hydrometallurgical process for the recycling of spent nickel-cadmium batteries.

The initial develupment focused on recovering pure materials (metallic nickel and cadmium); however, TNO realizes that this is relatively expensive, and the planned process does not take advantage of the economies of scale of a smelter. TNO is planning to conduct experiments to produce nickel salts and possibly cadmium salts, and plans to sell these products to smelters (van Erkel, 1992).

TNO's plan is to scale up the process to handle a feed stream of approximately 1,000 metric tons of nickel-cadmium batteries and approximately 1,500 metric tons of other nickel-bearing wastes. They plan to have the designs for the commercial facility completed in about one year. This plant will be large enough to treat all of the nickel-cadmium batteries disposed of in Holland, and may accept batteries or other wastes from Belgium and Germany. 


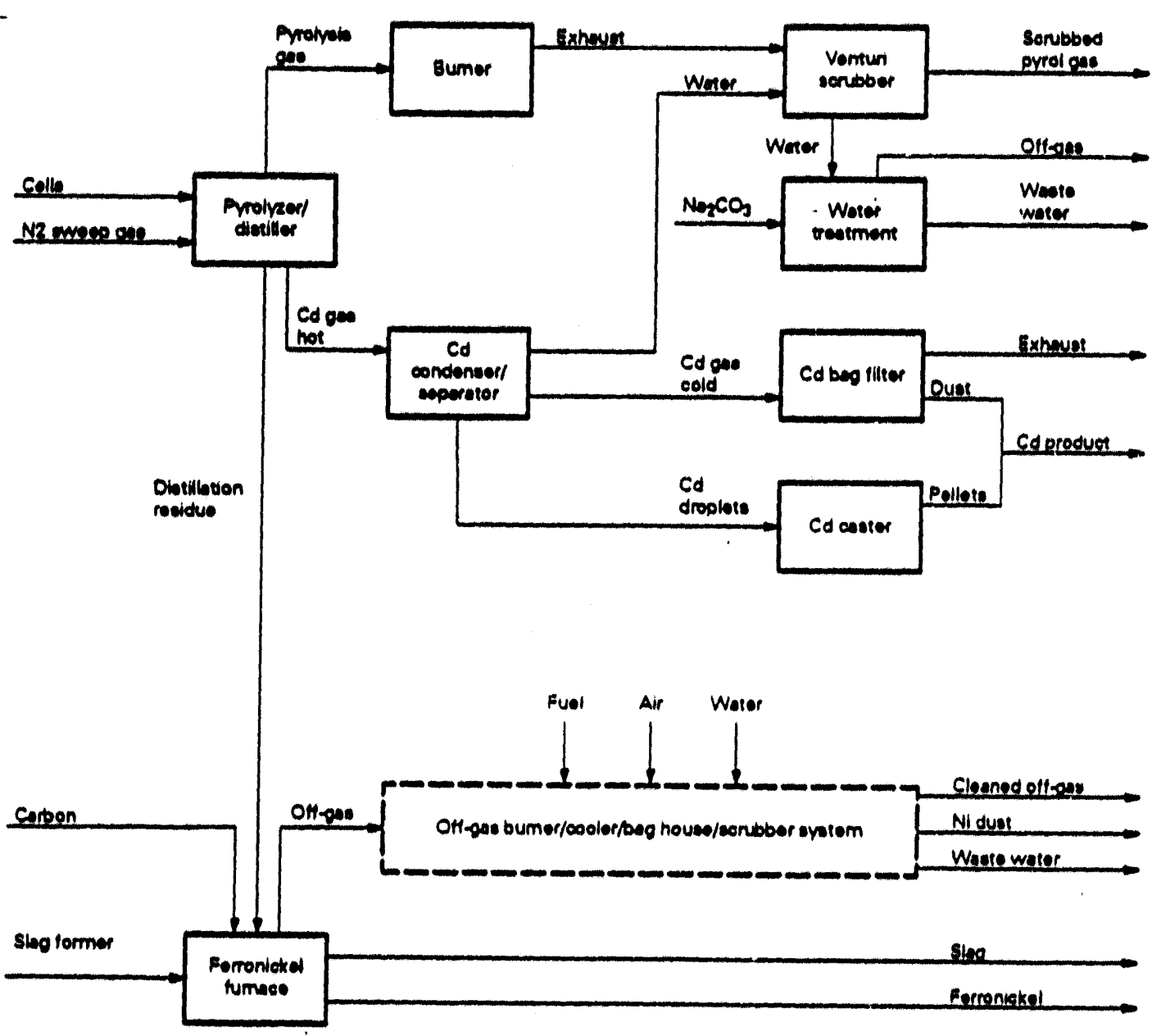

Souros: SNAMYSAVAM and Anhur 0 . Lmilo Eotimated

Figure 3-2: SNAM Process 
The TNO process for treating nickel-cadmium cells differs from other processes in that it operates entirely at ambient conditions, separating the metals by solvent extraction. Figure 3-3 shows the TNO process flow shect. The cells enter the process and are shredded in a knife mill and separated into three fractions by the use of magnetic separation and screening. The first fraction is ferrous scrap. The second material stream is plastics and paper. The third fraction is fines, which accounts for approximately one percent of the feed. All three fractions are leached with a 20 percent hydrochloric acid solution. This process extracts approximately one third of the iron, two-thirds of the nickel, and almost all of the cadmium contained in the battery feed. The solution is sent to solvent extraction with tributyl phosphate (TBP) in kerosene, selectively dissolving the cadmium chloride, which is extracted from the solution with hydrochloric acid and sent to an electrowinning operation to recover cadmium metal. The solution containing the unextracted nickel and iron is reacted with sodium hypochlorite and sodium hydroxide to precipitate the iron as a ferric hydroxide sludge. The solution is then sent to an electrowinning step to recover the nickel as nickel metal (van Erkel, 1991).

\subsection{NIFE}

NIFE operates two battery reclamation facilities, one in Sweden ano one in Greenville, North Carolina. The NIFE process was developed to process spent nickel-cadmium batteries and is similar to the SNAM process. The facility in North Carolina dismantles industrial batteries. The battery dismantling operation includes opening the battery case, draining and neutralizing the electrolyte, and separating the battery plates. The battery plates are then shipped to the plant in Sweden or sold on the scrap metals market to nickel and cadmium recyclers.

The plant in Sweden processes negative plates to extract cadmium and sends positive plates to steel mills for subsequent recovery of the nickel in steel making. The plant treats spent sealed cells separately. Initially, the cells are heated in a pyrolysis furnace to drive off the water and to pyrolyze the plastic constituents. The remaining residue from the small-sealed cells and the negative plates from the vented cells are processed together. This cacimium-containing material is heated to $900^{\circ} \mathrm{C}$ to volatize the cadmium, which is recovered as metallic cadmium. The remaining residue and the positive plates from the vented cells are sold to a steel maker. The plant recovers approximately 200 metric tons of cadmium annually. 


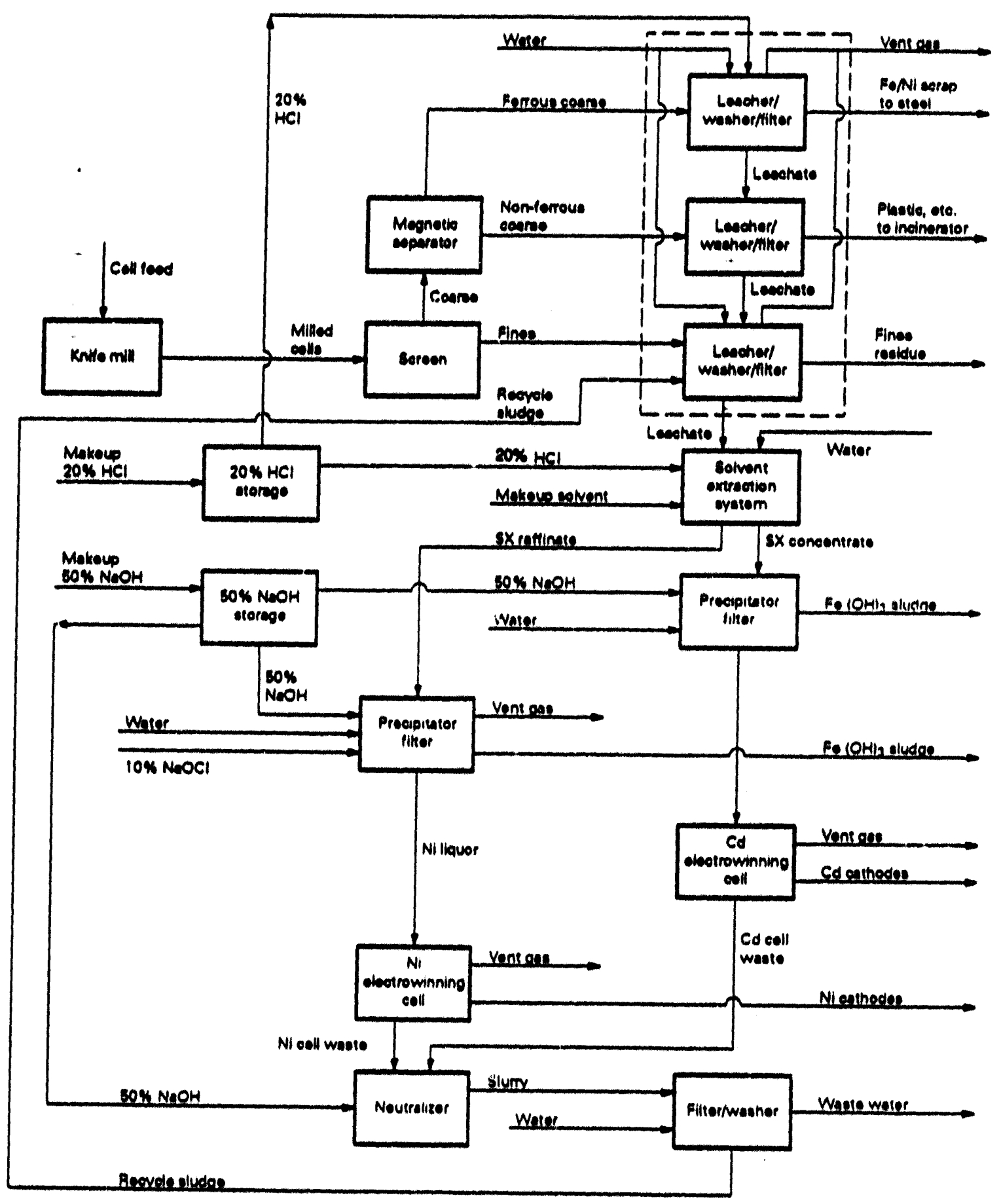

Souros: Arhur 0. Litre, ine. and TNO

Figure 3-3 TNO Process for N1-Cd Cells 


\subsection{Processes for Recycling $A B_{2}$ and $A B_{5}$ Alloy Electric Vehicle Batteries}

\subsection{Introduction}

This section of the report details processes for recycling the $A B_{2}$ and $A B_{3}$ nickel metal hydride battery. Because the composition of nickel metal hydride batteries is largely iron and nickel, our approach to determining possible recycling routes was initiated with an evaluation of the literature and review of operating conditions at plants which recycle nickel and iron bearing wastes. Our focus was on existing commercial or at least proven techniques for the reclamation of nickel-bearing wastes. The physical characteristics of the battery systems were also considered. Because of their significant size, the batteries should be simple to dismantle.

In the case of the $\mathrm{AB}_{2}$ system, the minor constituents (in our case, a vanadium-rich hydride alloy) were chosen as an example of a nickel metal hydride alloy chemistry to illustrate possible vanadium recovery techniques. The accompanying elements such as zirconium, titanium, chromium, and aluminum also behave differently in different chemical systems, and a comparison of the behavior of these elements is also discussed.

In the case of the $\mathrm{AB}_{5}$ system, the hydride alloy chosen for study was a misch metal rare earth, which is primarily nickcl and lanthanum. It is economically unattractive to consider separating the rare earths and recovering them in metallic form under current economic conditions. We expect the rare earth residues can be recovered by rare-earth metal producers using standard techniques. The other cell components, potassium hydroxide, and polypropylene, were also reviewed for possible recycling or disposal.

Much of the judgment for how these processes would behave and what the individual process steps might yield was formulated based upon previous experience in the dismantling of other large battery systems (e.g., SLI lead acid batteries and industrial nickel-cadmium cells), and the experience of operators of similar processes.

Three possible processes were evaluated, and economic analyses of the processes were conducted. The processes are based on similar techniques utilized for the reclamation of nickeland iron-bearing wastes. Also evaluated were processes used for the recycling of large nickelcadmium batteries. Based on these processes, three possible processes were evaluated.

The first process includes dismantling the battery, leaching the electrode materials in acid, and recovering nickel by electrowinning. This process is discussed in Section 4.2.

The second process is based on a pyrometallurgical process to melt the battery scrap and smelt the oxides and hydroxide compounds. The products would be primarily ferroalloys (iron alloys) such as ferronickel and ferrovanadium (in the case of $\mathrm{AB}_{2}$ batteries). This process is discussed in Section 4.3.

The third process is similar to the first process, except that the nickel hydroxide is leached in acid and the nickel is electrowon. The other materials are separated using various physical separation equipment (e.g., screens and magnetic separators) to produce fairly pure streams which can be returned to the metals industry. This process is described in Section 4.4.

Section 4.5 describes other possible recycling routes for the various process streams. 


\subsection{Chemical Process for $A B_{2}$ and $A B_{5}$ Alloy Systems}

\subsubsection{Process Description}

Figure 4-1 shows a leaching and electrowinning process based upon hydrochloric acid for handling $A B_{2}$ and $A B_{5}$ systems. In the first step of the process, individual EV batteries are disassembled manually from the battery packs. The batteries are placed upon a conveyor system which leads to the first machine, where the cell cases are ruptured from the bottom via a cutting torch or mechanical cutting device to enable the electrolyte in the battery to be removed. The second step entails the physical separation of the battery electrodes from the battery case. This process would be accomplished by cutting the battery case away from the electrodes and segregating the internal battery components from the battery case. The remaining battery components would be washed and the polypropylene separators would be separated from the electrodes by a gravity float and sink process in water. This separation would also allow for neutralization of residual potassium hydroxide.

The battery electrodes would then be fed into a shredder and granulator unit where the battery materials would be reduced to small pieces, probably less than three centimeters in cross section. The product of this milling operation would be screened and magnetically separated to produce a fraction of mostly nickel and iron and a fraction of nickel hydroxides and battery alloy. The material would then be subjected to screening and magnetic separation to remove the nickel and iron substrates from the residual powders.

The $\mathrm{Ni}(\mathrm{OH})_{2}$ and the active metal electrodes are leached and dissolved in aqueous hydrochloric acid. The leachate is partially neutralized, to a pH of 3 to 4 , to precipitate almost all the metals except the nickel (and the cobalt, if present). The resulting supernate is then sent to nickel electrowinning; the residual liquor from electrowinning is then totally neutralized for disposal, and the resulting precipitate is combined with the earlier precipitate. Cobalt will follow the nickel and be electrowon.

\subsubsection{Material Balances for $A B_{2}$ Systems}

The material balances for the process were developed using the following assumptions. With adequate draining and washing, all the potassium hydroxide and leveling additives are assumed to be removed from the cells. Scrap recovery of iron/nickel (from the cases) and of nickel/iron from the active metal electrode substrate, as well as and iron from the $\mathrm{Ni}(\mathrm{OH})_{2}$ (electrode substrate), is assumed to be 98 percent. Over half of the plant feed ends up in these scrap fractions. Any scrap not recovered directly is assumed to go to the leacher.

The plastic recovery is assumed to be total, with all the metal values washed off the plastic before it leaves the procers. A 20 percent excess of 20 percent hydrochloric acid is fed to the leacher, where the leach time is six hours and the temperature is $90^{\circ} \mathrm{C}$. Dissolution efficiency is assumed to be 98 percent; the washed fines residue leaves as an 80 percent "cake" for disposal. (The solids in this residue amount to about 0.6 percent of the plant feed.)

The iron dissolved in the leacher is assumed to be half in the ferrous state and half in the ferric state. Prior to the next step (hydroxide precipitation at a pH from 3 to 4), the ferrous ion is oxidized to ferric by treatment with sodium hypochlorite $(\mathrm{NaOCl})$ :

$$
2 \mathrm{FeCl}_{2}+2 \mathrm{HCl}+\mathrm{NaOCl}=2 \mathrm{FeCl}_{3}+\mathrm{NaCl}+\mathrm{H}_{2} \mathrm{O}
$$




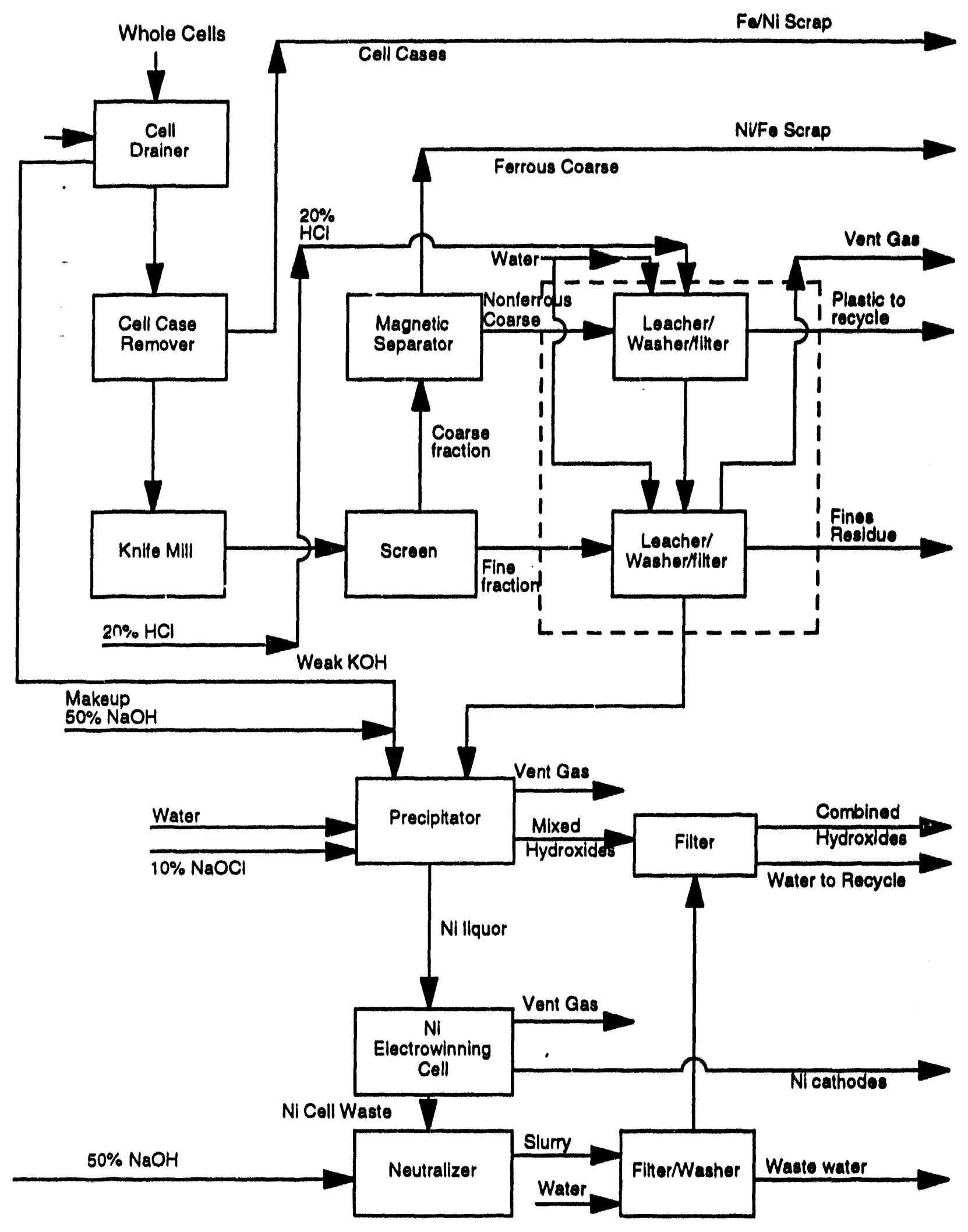

Figure 4-1: $A B_{2}$ and $A B_{5}$ Alloy Chemical Process 
A 200 percent excess of sodium hypochlorite is used; the excess sodium hypochlorite simply decomposes to oxygen and sodium chloride. In the precipitation at a $\mathrm{pH}$ of 3 to 4,5 percent of the nickel (and cobalt, if present) is assumed to precipitate, while 95 percent of all other metal ions is assumed to precipitate. In this step, the potassium hydroxide previously drained and washed from the cells is used to decrease the sodium hydroxide requirement. The washed hydroxide precipitate leaves this step as 70 percent solids. The supernate proceeds to the nickel electrowinning step.

In nickel electrowinning, it is assumed that 90 percent of any nickel, iron, chromium, or cobalt in solution is electroplated on cathodes. An equivalent amount of chlorine is generated at the anode. The stripped solution from electrowinning is then treated with a 5 percent excess of $\mathrm{NaOH}$, and the relatively small amount of resulting hydroxide precipitate is combined with that from the earlier precipitation. The supernate solution, containing $\mathrm{NaCl}, \mathrm{KCl}$, and excess $\mathrm{NaOH}$, is sent to an evaporation unit to produce a dry salt cake suitable for sale.

\subsubsection{Reasons For Choosing A Hydrochloric Acid Leach}

$\mathrm{HCl}$ was chosen as the dissolvent over sulfuric acid and nitric acid based on Bureau of Mines work (Lyman, 1993). They never achieved quite the degree of dissolution we assume, but they used four normal hydrochloric acid while we assume six normal hydrochloric acid, their temperature was $25^{\circ}-75^{\circ} \mathrm{C}$ while ours is $90^{\circ} \mathrm{C}$, and, most importantly, they were trying to dissolve whole cells, while we first subject our electrodes to a milling step.

Following the work of TNO (van Erkel, 1992), presented in Section 3.3, we evaluated the need for solvent extraction and found that it could be omitted from our process. This step was needed to separate the nickel and the cadmium from nickel-cadmium cells (within the TNO process) so that the nickel and cadmium could be separately electroplated. Because we have no cadmium, the solvent extraction step is unnecessary.

Instead, we depend on the other key TNO step, hydroxide precipitation at a pH of 3 to 4 , to separate the other metals from nickel prior to electrowinning. Here again the work of Lyman and Palmer (1993), is useful, because they tried this very approach on the solutions obtained from dissolving $\mathrm{NiMH}$ battery cells. In some cases, for $\mathrm{AB}_{2}$ batteries they achieved complete removal of iron, titanium, vanadium, zirconium, and chromium at a $\mathrm{pH}$ as low as 3.2, with the bulk of nickel still remaining in solution. Even at a $\mathrm{pH}$ as high as 4.5 , over 60 percent of the nickel remained in solution (above a pH of 4.5, nickel precipitated as a green hydroxide).

\subsubsection{Control of The Rare Earths and Subsequent Extraction}

One area of uncertainty is the extent to which the rare-earth elements (in the case of $A_{5}$ systems) will precipitate in the $\mathrm{pH}$ range of 3 to 4 . Fortunately, this does not really matter, as any unprecipitated rare earths will simply remain in solution through the nickel electrowinning step, only to be precipitated in the final treatment with $\mathrm{NaOH}$.

It might make sense to install a solvent extraction step if it were decided to separate the rare earths, in the $\mathrm{AB}_{5}$ case. Here, extracting the leachate with D2EHPA (di-2-ethylhexyl phosphoric acid) would separate a fraction containing iron, aluminum, and the rare earths, and this could then be treated with aqueous hydrofluoric acid to precipitate the rare-earth fluorides. One would then of course have to handle fluoride solutions, thus generating a fluoride-bearing waste stream. We considered this possibility and rejected it in favor of the much simpler process presented. 


\subsubsection{Plant Design Considerations for $A B_{2}$ Systems}

Scale of Operations-If we assume a feed of used cells at 30,000 metric tons per year, occurring over 300 operating days (24-hours pe day, this is 100 metric tons per day, or essentially 4.17 metric tons per hour). Good control can be obtained by operating in batches at each of the major steps, with storage capacity between steps to allow for delays and maintenance.

Milling-Portions of the milled metal are liable to become quite hot at the milling step. Since the active metal electrode alloy contains elements which can sometimes be pyrophoric, one ought to determine whether any special inerting capabilities ought to be built into the milling operation.

Leaching-Since the initial draining, screening, and magnetic separation split off some 10 percent of the feed as drained electrolyte, 56 percent as metal scrap, and 5 percent as plastic scrap, this leaves only 29 percent of our 4.17 metric tons per hour, or 1.2 metric tons per hour to be leached with hydrochloric acid. Assuming an 8-hour leacher cycle (allowing for charge, heatup, 6-hour leach, cooldown, and discharge), we handle $8 \times 1.2=9.6$ metric tons per batch, if we use only one leacher.

The material balance shows that this 9.6 metric tons is composed of about 4.2 metric tons of $\mathrm{Ni}(\mathrm{OH})_{2}$ and 5.4 melric tons of active metal alloy. Assuming respective bulk densities of 2 and 3 metric tons $/ \mathrm{m}^{3}$, the solids charged will occupy $3.9 \mathrm{~m}^{3}\left(138 \mathrm{ft}^{3}\right)$. The 84 metric tons of 20 percent hydrochloric acid charged will occupy $77 \mathrm{~m}^{3}\left(2,710 \mathrm{ft}^{3}\right)$, but this large liquid volume does not all have to be in the leacher, if we continuously circulate the acid through the metal. Thus, allowing for some freeboard (to allow for volume expansion), a $10 \mathrm{~m}^{3}$ ( $350 \mathrm{ft}^{3}$, or $2,600 \mathrm{gal})$ dissolver and a $90 \mathrm{~m}^{3}\left(3,180 \mathrm{ft}^{3}\right.$ or $\left.23,800 \mathrm{gal}\right)$ tank through which the heated acid is continuously pumped, would suffice.

In view of the sizes given above, and to achieve added flexibility, it might be better to utilize two systems in parallel, each with vessels one-half as big. We have made this assumption in the cost estimate. The leachers should be hard-rubber-lined steel pressure vessels with a tantalum-clad agitator, while the pumps, heat exchangers, and pipes which handle the six normal hydrochloric acid should be tantalum or glass-lined steel, but the associated large tanks can be of glassed-steel construction, or other corrosion resistant materials capable of handling the high temperature of the leacher discharge, because they see no metallic solids.

Other schemes, where the acid is added to the system in portions and replaced as it becomes spent, also are possible; however, every 8 hours, 9.6 metric tons of solids must be leached by 84 metric tons of hot acid. In any scheme chosen, the amount of residual undissolved material is small, so it would make sense to leave the undissolved "heel" in the dissolver from batch to batch until its volume grows to such proportions that it must be removed for washing and disposal.

The leaching should be carried out in closed vessels, because the vapor pressure of hydrochloric acid above 20 percent solution at $90^{\circ} \mathrm{C}$ is appreciable $(28.1 \mathrm{~mm}$ mercury), and hydrogen will be evolved. The hydrogen formed during dissolution will thus cause pressurization. The total hydrogen from 8 hour's worth of operation is 0.3 metric tons in the $\mathrm{AB}_{2}$ case, or enough to pressurize the system to thousands of psi if not vented. It thus must be continuously vented (cold, to prevent hydrochloric acid loss), probably to a flare, in order to maintain a controlled pressure in the leach system. 
Leachate Treatment-Leachate can be collected in a storage system, so the ensuing treatment step can be of any convenient batch size. Since, with good mixing, the addition of sodium hypochlorite solution for ferrous oxidation should be rapid, necessitating approximately 10 minutes, and since sodium hydroxide addition and precipitation can be accomplished in about 20 minutes, it is really the filtration and washing which dictates the cycle time. Let us assume that we can treat the leachate in two precipitator/filter systems, each with a cycle time of three hours. Each system thus sees batches of $(1 / 2) \times(3 / 8) \times(9.6+84)=18$ metric tons of leachate. With the addition of 2.0 metric tons of 10 percent $\mathrm{NaOCl}$ and 5.1 metric tons of 50 percent sodium hydroxide, the final slurry in each system amounts to about 25 metric tons, occupying $23 \mathrm{~m}^{3}$ ( $800 \mathrm{ft}^{3}$ or $6200 \mathrm{gal}$ ). A pair of 8000 -gallon high-alloy stainless steel vessels, baffled and well-agitated, should thus suffice for the precipitation step.

The filter of each system (assume rotary filters) should be capable of separating the resulting 2.7 metric tons of wet hydroxide sludge from each batch in, perhaps, two hours, with continuous cake washing and doctor-blade cake removal.

Nickel electrowinning-The $\mathrm{AB}_{2}$ plant would produce approximately $301 \mathrm{~kg} / \mathrm{hr}$ (2167 metric tons/year) of cathode material. Sumitomo Metal Mining Co., Ltd. has published a paper describing a nickel electrowinning plant like this one, operating on chloride solutions (N. Fujimori, 1982). The Sumitomo plant nickel cathode output was rated at 2500 metric tons/year.

The Sumitomo plant had 24 cells in the nickel circuit, each of $7 \mathrm{~m}^{3}$ size, for a total holdup of $168 \mathrm{~m}^{3}$. In our $\mathrm{AB}_{2}$ electrowinning step, the input nickel concentration to the cells is about 25 $\mathrm{kg} / \mathrm{m}^{3}$, not far from Sumitomo's $50 \mathrm{~kg} / \mathrm{m}^{3}$. We could thus plan on also having a holdup of $0.867 \times(50 / 25) \times 168=291 \mathrm{~m}^{3}$. We could achieve this by using 42 of the Sumitomo-size: ( 7 $\mathrm{m}^{3}$ ) cells. This part of the process would operate continuously.

The chlorine produced as a by-product can be processed to recover hydrochloric acid for use in the leaching system, or the chlorine can simply be dried, compressed, and sold for by-product credit.

Waste Neutralization-This step is a repetition of the Leachate Treatment step described above, but without the need for sodium hypochlorite addition. If we again assume a pair of neutralizers, each operating on a 3-hour cycle, each unit will produce a batch of 24 metric tons of slurry, occupying $22 \mathrm{~m}^{3}$ ( $770 \mathrm{ft}^{3}$ or $6000 \mathrm{gal}$ ). Again, 8000-gallon agitated vessels should suffice. The slurry, with its relatively small amount of solids, would be sent to the leachate rotary filter for subsequent dewatering.

The waste solution is about 17 percent sodium chloride and one percent potassium chloride, with a slight excess of sodium hydroxide. All electrolyte additives are assumed to go with the potassium hydroxide. If a desert location is assumed, it would be possible to spread this material out for solar evaporation to deposit dry salts (the sodium hydroxide would be changed by the carbon dioxide in the air to sodium carbonate). In the $\mathrm{AB}_{2}$ case, we would have to evaporate some 93,000 metric tons of water per year, or 75 acre-feet of water per year. In a location where net evaporation is, say, 60 inches per year, this would require a minimum land area of some 15 acres. The evaporation would deposit roughly $(18 / 82) \times 93,000=20,400$ metric tons of salts per year; in a lagoon of 15 acres, the deposit would accumulate in thickness at roughly 8 inches per year, so after some time it would be necessary to remove the salt 
periodically for sale. Solar evaporation would not be possible, elsewhere requiring additional investment in mechanical/thermal evaporation systems.

\subsubsection{Plant Design Considerations for $A B_{5}$ Systems}

In the case of $A B_{5}$ systems, the process plant scale was the same as $A B_{2}$ systems. The milling and leaching operations were similar. For details of the process, the reader is referred to Section 4.2.5.

In the leaching step, the material balance shows that this 9.6 metric tons is composed of about 4.2 metric tons of $\mathrm{Ni}(\mathrm{OH})_{2}$ and 5.4 metric tons of active metal alloy. Assuming respective bulk densities of 2 and 3 metric tons $/ \mathrm{m}^{3}$, the solids charged will occupy $3.9 \mathrm{~m}^{3}\left(138 \mathrm{ft}^{3}\right)$. For the $\mathrm{AB}_{5}$ case, the 61 metric tons of 20 percent hydrochloric acid charged will occupy $64 \mathrm{~m}^{3}$ $\left(2,250 \mathrm{ft}^{3}\right)$, but this large liquid volume does not all have to be in the leacher, if we continurously circulate the acid through the metal. Thus, allowing for some freeboard (for volume expansion), an $8 \mathrm{~m}^{3}$ (300 $\mathrm{ft}^{3}$ or $\left.2300 \mathrm{gal}\right)$ dissolver and a $75 \mathrm{~m}^{3}\left(2,640 \mathrm{ft}^{3}\right.$, or 20,500 gal) tank through which the heated acid is continuously pumped, would suffice. The leaches would be similar in design to those discussed in Section 4.2.5.

The leaching should again be carried out in closed vessels. The hydrogen formed during dissolution will cause pressurization. The total hydrogen from 8 hours' operation is 0.2 metric tons in the $\mathrm{AB}_{5}$ case. It thus must be continuously vented (cold, to prevent acid loss), probably to a flare, in order to maintain a controlled pressure in the leach system.

Leachate Treatment-Leachate can be collected in a storage system, so the ensuing treatment step can be of any convenient batch size. Because, with good mixing, the addition of $\mathrm{NaOCl}$ solution for ferrous oxidation should be rapid, necessitating approximately 10 minutes, and since sodium hydroxide addition and precipitation can be accomplished in about 20 minutes, it is really the filtration and washing which dictates the cycle time. Let us assume that we can treat the leachate in two precipitator/filter systems, each with a cycle time of 3 hours. Each system thus sees batches of $(1 / 2) \times(3 / 8) \times(9.6+61)=13$ metric tons of leachate. With the addition of 2 metric tons of 10 percent $\mathrm{NaOCl}$ and 2.4 metric tons of 50 percent sodium hydroxide, the final slurry in each system amounts to about 17.4 metric tons, occupying $16 \mathrm{~m}^{3}$ $\left(600 \mathrm{ft}^{3}\right.$, or $\left.4,800 \mathrm{gal}\right)$. A pair of 5,000-gallon, rubber-lined alloy steel vessels, baffled and well-agitated, should thus suffice for the precipitation step.

The filter of each system (assume rotary filters) should be capable of separating the resulting 2.2 metric tons of wet hydroxide sludge from each batch in, perhaps, 2 hours, with continuous cake washing and doctor-blade cake removal.

Nickel Electrowinning-The $\mathrm{AB}_{5}$ plant would produce approximately $538 \mathrm{~kg} / \mathrm{hr}$ (3867 metric tons/year) of cathode material. Sumitomo Metal Mining Co., Ltd., has published a paper describing a nickel electrowinning plant like this one, operating on chloride solutions (Fujimori, Eujimori, et al., 1982). The Sumitomo plant nickel cathode output was rated at 2,500 metric tons per year; thus, our plant is 1.55 times as large.

The Sumitomo plant had 24 cells in the nickel circuit, each of $7 \mathrm{~m}^{3}$ size, for a total holdup of $168 \mathrm{~m}^{3}$. In our $\mathrm{AB}_{5}$ electrowinning step, the input nickel concentration to the cells is about 57 $\mathrm{kg} / \mathrm{m}^{3}$, not far from Sumitomo's $50 \mathrm{~kg} / \mathrm{m}^{3}$. We could thus plan on also having a holdup, in 
the $\mathrm{AB}_{5}$ case, of $1.55 \times(50 / 57) \times 168=228 \mathrm{~m}^{3}$. We could achieve this by using 33 of the Sumitomo-sized $\left(7 \mathrm{~m}^{3}\right)$ cells. This part of the process would be operated continuously.

The chlorine produced as a by-product ( 4,704 metric tons per year) can be processed to recover hydrochloric acid for use in the leaching system, or the chlorine can simply be dried, compressed, and sold for by-product credit.

Waste Neutralization-This step is a repetition of the Leachate Treatment step described above, but without the need to add sodium hypochlorite. If we again assume a pair of neutralizers each operating on a 3-hour cycle, each unit will produce, in the $\mathrm{AB}_{5}$ case, a batch of 16 metric tons of slurry, occupying $15 \mathrm{~m}^{3}$ ( $530 \mathrm{ft}^{3}$, or 4,100 gal). Again, 5,000-gallon agitated vessels should suffice. The slurry would be sent to the rotary leachate filter for subsequent dewatering.

The waste solution case is about 14 percent sodium chloride and two percent potassium chloride with a slight excess of sodium hydr ide. It also is assumed to contain all the leveling additives which were in the cell electrolyte. If a desert location is assumed, it would be possible to spread this material out for solar evaporation to deposit dry salts (the sodium hydrc by the carbon dioxide in the air to sodium carbonate). In the $\mathrm{AB}_{5}$ case, we would have to evaporate some 67,260 metric tons of water per year, or 54 acre-feet of water per year. In a location where net evaporation is, say, 60 inches per year, this would require a minimum land area of some 10.5 acres. The evaporation would deposit roughly $(16 / 84) \times 67,260=12,800$ metric tons of salts per year; in a lagoon of 9 acres, the deposit would accumulate at roughly 8 inches per year, so after some time it would be necessary to remove the salt for sale. For other regions, where solar evaporation is not practical, mechanical/thermal evaporation techniques need to be used.

\subsection{Pyrometallurgical Process}

\subsubsection{Process Description for $A B_{2}$ Systems}

Figure 4-2 shows a pyrometallurgical process for the recovery of ferronickel and ferrovanadium from spent $A B_{2}$ systems. In the first step of the process, individual $E V$ batteries are disassembled from the battery packs manually. The batteries are placed upon a conveyor system which leads to the first machine where the cell cases are ruptured from the bottom via a cutting torch or mechanical cutting device to enable the electrolyte in the battery to be removed. The second step is the physical separation of the battery electrodes from the battery case. This would be accomplished by cutting the battery case away from the electrodes and segregating the internal battery components from the battery case. The remaining battery components would be washed and the polypropylene separators would be separated from the electrodes by a gravity float-and-sink process in water. This separation would also allow for neutralization of residual potassium hydroxide.

Because approximately 30 percent of the battery weight is nickel-plated steel from the battery case, which is probably 97 percent iron, it is highly desirable from an economic point of view not to melt this material with the nickel-bearing scrap. The value of the iron is minimal, while the mixing of iron with nickel reduces the value for the ferronickel, increases the size of the process equipment needed to process the metal, and does not increase the market value of the iron. Therefore, we chose to simply separate the steel scrap from the high-nickel material of the battery electrodes. 
The polypropylene is separated because of emissions problems which would occur with the combustion of polypropylene, as occurred in the past with lead-acid battery recycling. (Lead acid battery recyclers no longer combust the plastic; rather, these companies reuse the polypropylene in the manufacture of new batteries and other uses.) It is necessary to remove the potassium hydroxide from the material to be smelted because potassium corrodes to furnace refractories and degrades the slag product.

The battery electrodes are introduced to a tunnel dryer in order to remove any surface water to prevent explosions in the electric arc furnace. The scrap electrodes would be preheated to approximately $300^{\circ} \mathrm{C}$ in the dryer. The dried electrodes would be transferred to the electric furnace. within a scrap bucket and introduced to the furnace by the removal of the furnace top, an approach which is practiced widely in the metals industry. Silica sand and lime would be added in the proper proportions to make a fluxing material, and iron ore would be added in the proper ratio to oxidize the vanadium, zirconium, titanium, chromium, and aluminum. The nickel oxides would be preferentially reduced by the addition of coke.

Once the metals have been melted, the vanadium-bearing slag is poured from the furnace and into a transfer ladle. This slag is moved to an area for subsequent addition to another electric arc furnace for reduction of the vanadium. The slag should be added to the furnace in a molten condition to reduce the need for additional energy to heat the slag. The remaining crude ferronickel is transferred to the converting furnace to remove the residual metallic contaminant. In the process of transferring the ferronickel, ferrosilicon is added to the ladle to further remove impurities and to supply additional chemical energy to maintain temperature.

At the converter, oxygen is injected into the crude molten ferronickel for further refining, removing substantially all of the vanadium, zirconium, titanium, chromium, and aluminum remaining, and producing a pure ferronickel product. The ferronickel is poured from the converter into a transfer ladle and is moved to the casting area where it is cast into pigs for subsequent sale to the steel industry. Further slag removal may be required to clean the surface of the cast pigs, which is done in a tumbling mill where sand is used to clean the pig surfaces.

The vanadium-rich slag which had been sent to the second electric arc furnace is heated and aluminum metal is added to preferentially reduce the vanadium and iron while leaving the remaining constituents in the slag. The ferrovanadium product is cast into pigs and processed in a similar way to the ferronickel, without utilizing a converting step.

The slag generated in the ferrovanadium production step is recycled back to the first ferronickel furnace because of the contained nickel. Periodically, this slag will be bled from the furnace and disposed. The slag from the ferrovanadium operation will be solidified, crushed, screened, and sold for road-building applications. The slag may have some use in the refractory industry.

All furnace exhausts should be treated in a cyclone/baghouse combination to reduce the particulate loading of the emissions. It is unclear at this time whether this will be sufficient to meet potential emissions control regulations ten years from now. Additionally, all plant fugitive emissions, which will be significant during the addition of scrap and the pouring of metal and slag should be collected and treated in a similar way. It is assumed that all baghouse dusts can be recycled back into the process, but a small quantity will need to be disposed of periodically. 


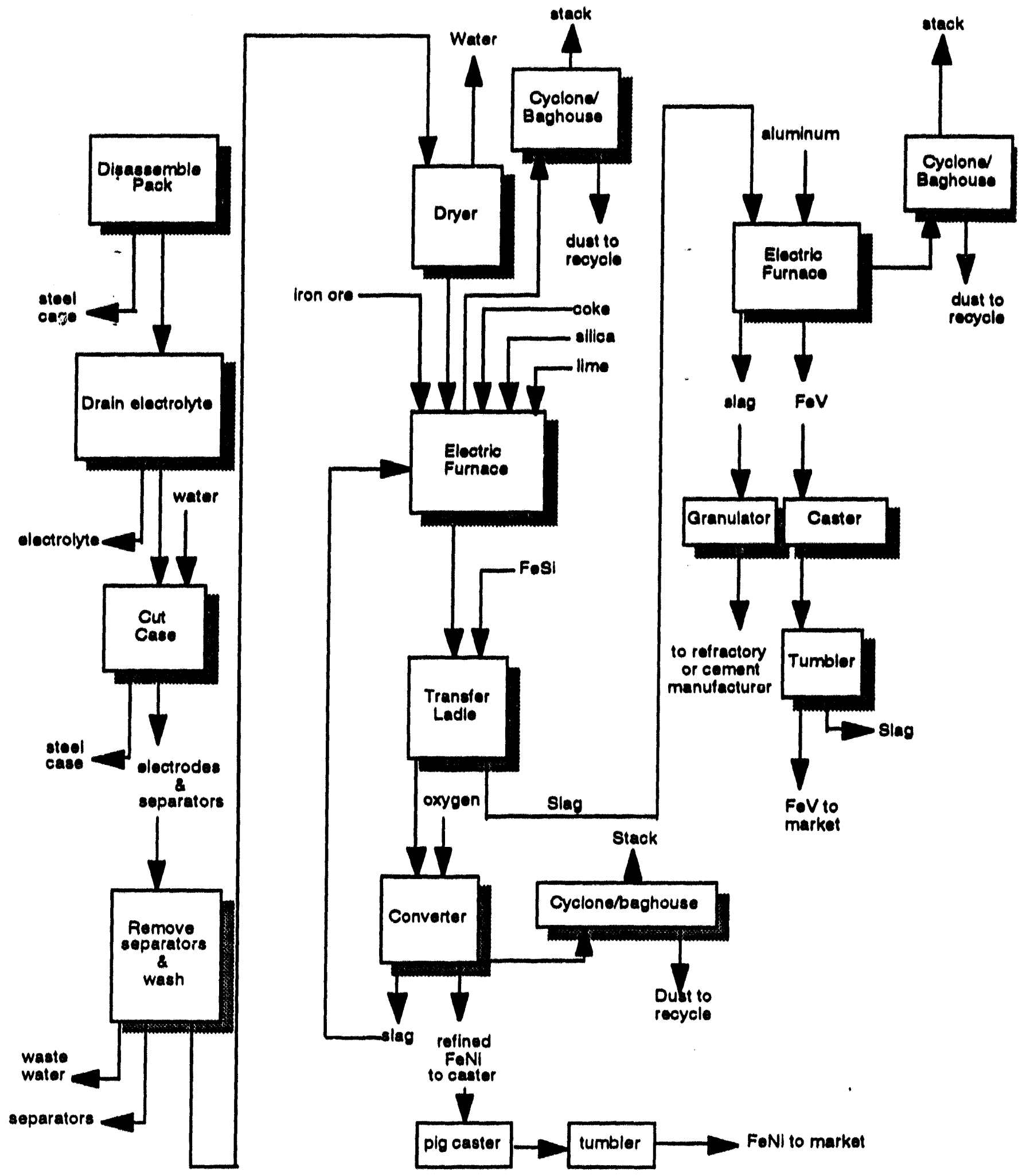

Figure 4-2: $\mathrm{AB}_{2}$ Alloy Pyrometallurgical Process 


\subsubsection{Material Balance for $A B_{\text {: }}$ Systems}

This material halance is based upon 1,(OCX) kilograms of spent $A B_{2}$ nickel metal hydride batteries using the $\mathrm{AB}_{2}$ system. The material balance calculations are found in $A$ ppendix $A$. Approximately 75 kilograms of electrolyte is removed in the electrolyte draining operation. Approximately 285 kilograms of 97 percent steel scrap is removed in the case removal step. Of the 1,00) kilograms, approximately 50 kilograms of separators can be removed in the washing step. The remaining 25 kilograms of electrolyte is also removed in this step while approximately 563 kilograms of material is left for feeding into the electric arc furnace. The feed is primarily nickel and iron with smaller amounts of the refractory metal alloy. Approximately 69 percent of the feed is nickel and stecl. The resulting crude ferronickel is approximately 57 percent iron and 41 percent nickel. Approximately 537 kilograms of ferronickel is recovered. In addition, approximately 264 kilograms of slag is generated and sent to the second electric arc furnace to produce ferrovanadium.

The 537 kilograms of crude ferronickel is refined in the converter with ferrosilicon and oxygen to produce approximately 471 kilograms of ferronickel, which is almost 54 percent nickel and has less than 0.2 percent residual elements. In order to produce this ferronickel, approximately 252 kilograms of iron ore, 40 kilograms of coke, 25 kilograms of ferrosilicon, and 19 kilograms of oxygen were needed.

The ferrovanadium fumace feed is approximately 332 kilograms of slag, and it produces approximately 99 kilograms of ferrovanadium alloy containing 58 percent vanadium. 17 percent chromium, 10 percent nickel, and 14 percent iron. This alloy, though unusual, could be used in the production of certain tool steels, High Strength, Low Alloy steels, and in certain steels which used vanadium in place of molybdenum for improved corrosion resistance.

The remaining slag from the ferrovanadium production could be used in various construction applications and possibly in refractory manufacturing. To produce the ferrovanadium. approximately 68 kilograms of aluminum is used.

In the high-temperature process steps, yiclds of iron, nickel, and vanadium were taken as 90 percent to the metals and 5 percent of the residual elements to the metal, while the opposite was true for the slags and dusts. Approximately 93 percent of the residual elements went to the slag and 2 percent went to the dusts. The exception to this was the converter, where the dusts accounted for approximately 5 percent of the feed weight. These values are typical for ferroalloy production.

\subsubsection{Process Description for $A B_{5}$ Systems}

Figure 4-3 shows a pyrometallurgical process for the recovery of ferronickel from spent $A B_{5}$ systems. The process is essentially the same as the process for $\mathrm{AB}_{2}$ cells until the electric furnace. From then on, the process differs. For details of the initial steps of the process, the reader is referred to Section 4.3.1.

The dried electrodes would be transferred to the electric furnace within a scrap bucket and introduced to the furnace by the removal of the furnace top, an approach which is practiced widely in the metals industry. Silica sand and lime would be added in the proper proportions to make a fluxing material and iron ore would be added in the proper ratio to oxidize the rare earth metals, manganese, and aluminum. The cobalt will follow the nickel throughout the process. The nickel and cobalt oxides would be preferentially reduced by the addition of coke. 
Once the metals have been melted, the rare-earth-bearing slag is poured from the furnace and into a transfor ladle. This slag is then moved to an area for solidilication and granulation. It is unlikely that the rare earths could be further processed at the plant economically, because most rare-earth-metal production is done by converting the rare-earth oxides to fluorides and reducing the fluorides with calcium or other active metals. We expect that the rare-earth material can he disposed to rare-earth manufacturers who have plants at sufficient scale to handle these materials.

In the process of transferring the ferronickel, ferrosilicon is added to the ladle to remove more impurities and to supply additional chemical energy to maintain temperature.

At the converter, oxygen is injected into the crude molten ferronickel to further refine the ferronickel, removing substantially all of the remaining rare earths, manganese, and aluminum and producing a pure ferronickel product. The ferronickel is poured from the converter into a transfer ladle and is moved to the casting area, where it is cast into pigs. The casting of slags and metal and the pollution control systems would be similar to those of the $\mathrm{AB}_{2}$ pyrometallurgical plant described in Section 4.3.1.

\subsubsection{Material Balance for $A B_{s}$ Systems}

The basis of the material balance (shown in Appendix A) is 1,000 kilograms of spent nickel metal hydride batteries utilizing the $\mathrm{AB}_{5}$ system. Approximately 75 kilograms of electrolyte is removed in the draining operation and approximately 285 kilograms of 97 percent steel scrap is removed in the case removal step. Of the 1,000 kilograms, approximately 50 kilograms of separators can be removed in the washing step. Additionally, the remaining 25 kilograms of electrolyte is also removed in this step. Approximately 563 kilograms of material is left for feeding into the electric arc furnace. The feed is primarily nickel and iron with smaller amounts of the rare-earth metals, cobalt, manganese, and aluminum. Approximately 78 percent of the feed is nickel and steel. The crude ferronickel produced is approximately 56 percent nickel and 40 percent iron. Approximately 472 kilograms of ferronickel is recovered. In addition, approximately 156 kilograms of slag is generated.

The 472 kilograms of crude ferronickel is refined in the converter with ferrosilicon and oxygen to produce approximately 422 kilograms of ferronickel, which is almost 56 percent nickel, 3.3 percent cobalt, and has less than 0.1 percent residual elements. In order to produce this ferronickel, approximately 62 kilograms of iron ore, 40 kilograms of coke, six kilograms of ferrosilicon, and 27 kilograms of oxygen were needed. The remaining slag from the ferronickel production is high in rare-earth content. This slag could be sold to rare-earth processors or processed on site. Approximately 156 kilograms of the slag containing approximately 59 percent rare-earth oxides is recovered. The remainder is nickel, iron, manganese, and aluminum oxides.

In the high temperature process steps, yields of iron, nickel, and cobalt were taken as 90 percent going to the metals and 5 percent of the residual elements going to the metal, while the opposite was true for the slags and dusts. Approximately 93 percent of the residual elements went to the slag and two percent went to the dusts. The exception of this was the converter, where the dusts accounted for approximately 5 percent of the feed weight. 


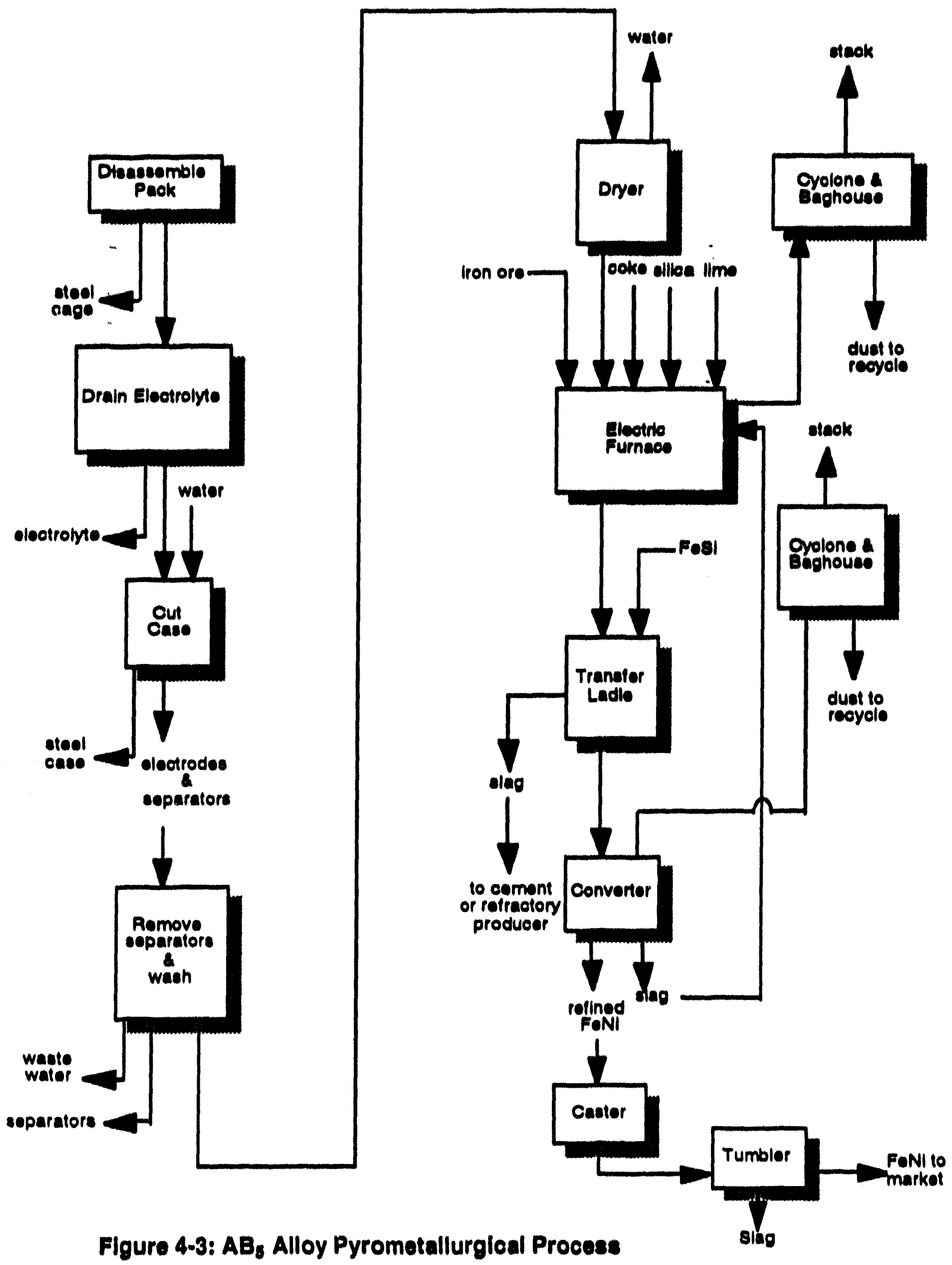




\subsubsection{Plant Design Consideration for $A B_{2}$ Systems}

The primary process unit in the plant is a 6-MW electric arc fumace. It is expected that the lurnace will have an operating temperature of approximately $1,7(X)^{\circ} \mathrm{C}$. This temperature is required hecause of the high melting temperature of the hydride alloys. Operations at $1,700^{\circ} \mathrm{C}$ alw reguire significant invesument in refractory materials. We would expect the refractory niulcrials to be primarily carbon brick and magnesia-rich refractory. The chemistry of the slag will significantly affect the performance and productivity of the furnace. We expect a feed of 2.3 metric tons of battery materials, with the addition of nuxes and iron oxides bringing this up to approximately 3.64 metric tons of feed per hour. It is expected that the furmace cycle will be approximately four hours, requiring a holding capacity of 14.5 metric tons. It is anticipated that $1,650 \mathrm{kWh}$ per metric ton of feed will be required.

The product of the furnace will be crude ferronickel, which will require further refining using a converter. (A converter is a process vessel used for refining metals with additions of gasses, alloys, and other refining agents.) The converter will have a one-hour cycle time, but will be required to have a holding capacity necessary for a full furnace charge. Based on a four-hour tap-to-tap time for the electric arc furnace, the required holding capacity of the converter will be approximately eight metric tons. The converter will be similar in design to an argon-oxygen decarburization vessel, a tall vertical vessel with an extended pouring spout. The vessel will be equipped with a removable gas burner for preheating and supplemental heating. Tuyeres (porous plugs or pipes) will be in place to inject argon for stirring, and oxygen will be injected by a lance. The vessel will be designed to pour to a transfer ladle for subsequent casting of the ferronickel.

The other major process vessel will be a $2-\mathrm{MW}$ electric arc furnace used to recover ferrovanadium from the ferronickel slag. The furnace will be designed to process approximately 5.5 metric tons of material in a four-hour batch. Aluminum will be used as a reductant and will require only small quantities of energy to begin the reaction, because the exothermic reaction of vanadium oxide with aluminum. The furnace will produce approximately 1.6 metric tons of ferrovanadium alloy per four-hour batch.

The ferronickel and ferrovanadium will be cast on horizontal pig casters, with products which will be of a useful size for the steel industry. Additionally, larger size castings can be produced by conventional ingot-casting techniques.

The process vessels will be equipped with cyclone and baghouse pollution-control devices to control particulate emissions. It is anticipated that this will be sufficient control for the plant. Additionally, plant fugitive emissions will be filtered in a cyclone-and-baghouse combination. The converter vessel baghouse will be designed for handling the higher temperature of the emissions with significant dilution air added, as well as heat exchangers and possibly fiberglass bags. The controls will be similar to those used in conventional metallurgical facilities.

The slag produced by the process will be allowed to solidify and will then be crushed and screened for resale. A two-ton-per-hour jaw crusher will be used.

\subsubsection{Plant Design Consideratlons for $A B_{5}$ Systems}

The primary process unit in the plant is a 6-MW electric arc furnace. It is expected that the furnace will have an operating temperature of approximately $1,5(X))^{\circ} \mathrm{C}$. Operations at $1,500^{\circ} \mathrm{C}$ will require significant investment in refractory materials. We would expect the refractory 
matcrials to be primarily carbon brick and magnesia-rich refractory. The chemistry of the slag will significantly affect the performance and productivity of the furnace. We expect a feed of 2.35 metric tons of battery materials with the addition of fluxes and iron oxides bringing this up to approximately 3.0 metric tons of feed per hour. It is expected that fumace cycle will be approximately 4 hours, requiring a holding capacity of 12 metric tons. It is also anticipated that $1,5(X) \mathrm{kWh}$ per metric ton of feed will be required.

The product of the furnace will be a crude ferronickel product which will require further refining using a converter. The converter will be considered to have a 1-hour cycle time, but will be required to have a holding capacity necessary for a full furnace charge. Based on a 4hour tap-to-tap time for the electric arc furnace, the required holding capacity of the converter will be approximately 8 metric tons. The converter will be similar in design to an argonoxygen decarburization vessel, a tall vertical vessel with an extended pouring spout. Argon will be introduced through tuyeres at the base and oxygen via a lance. The vessel will be equipped with a removable gas bumer for preheating and supplemental heating. The vessel will be designed to pour to a transfer ladle for subsequent casting of the ferronickel.

The ferronickel will be cast on a horizontal pig caster, which will make products of a useful size for the steel industry. Additionally, larger size castings can be produced by conventional ingot casting techniques.

The process vessels will be equipped with cyclone and baghouse pollution control devices to control particulate emissions. This should provide a sufficient measure of control for the plant. Additionally, plant fugitive emissions will be filtered in a cyclone- and-baghouse combination. The converter vessel baghouse will be designed for handling the higher temperature of the emissions with significant dilution air added, heat exchangers, and possibly fiberglass bags in the baghouse. The controls will be similar to those used in conventional metallurgical facilities.

The slag prodisced by the process will be allowed to solidify and will then be crushed and screened for resale. A two-ton-per-hour jaw crusher will be used. This slag will be rich in rare earths and will be sold to rare-earth processors.

\subsection{Physical Separation/Chemical Process}

\subsubsection{Process Description}

Figure 4-4 shows a physical separation, leaching, and electrowinning process based upon hydrochloric acid for handling $A B_{2}$ and $A B_{9}$ systems. In the first step of the process, individual EV batteries are disassembled from the battery packs manually. The batteries are placed upon a conveyor system which leads to the first machine, where the cell cases are ruptured from the bottom via a cutting torch or mechanical cutting device to enable the electrolyte in the battery to be removed. The second step is the physical separation of the battery electrodes from the battery case. This would be accomplished by cutting the battery case away from the electrodes and separating the internal battery components from the battery case.

The remaining battery components would be washed and the polypropylene separators would be separated by hand. Hand separation is practiced by several recyclers of large nickelcadmium and zinc-carbon cells. We anticipate that because of the construction of the cells, current collectors will be cut preferentially, to separate the hydride alloy electrodes from the nickel hydroxide electrodes. The separated electrodes and polypropylene separators could then be washed to remove any residual potassium hydroxide. 
The separated polypropylene would be sent for recycling. The nickel-hydroxide- containing electrodes would be sent to a leaching circuit, requiring a milling operation previous to leaching to reduce size and a magnetic separation step to remove any nickel and iron from the nickel hydroxide powders.

The nickel hydroxide electrode powder would be leached in hydrochloric acid in a similar way to the chemical process discussed in Section 4.2. The resulting solution would be sent to electrowinning. The residual liquor from the electrowinning operation would be neutralized with sodium hydroxide.

The remaining hydride alloy electrodes would be sent to a hammermill or similar sizereduction machine. The product of the milling would be screened and sent to magnetic separation to remove most of the free nickel, leaving a powder which is mostly the hydride alloy powder. The material would be retumed to the battery alloy producer to recover the metallic values of the alloy. Additional virgin materials would need to be added to the powder to retum the alloy to a composition similar to that of new battery alloys. The residual nickel which is not removed in the magnetic separation step would be returned with the hydride alloy. The residual nickel chips could be returned to the nickel industry, or returned to the battery manufacturer for reuse in batteries.

\subsubsection{Materlal Balances}

The details of the material balances are shown in Appendix A. The material balances for the process were developed using the following assumptions. With adequate draining and washing, all the potassium hydroxide and additives are assumed to be removed from the cells. Scrap recovery of iron and nickel (from the cases) and of nickel and iron (iron and nickel from the active metal electrode substrate and nickel from the $\mathrm{Ni}(\mathrm{OH})_{2}$ electrode substrate) is assumed to be 98 percent. Over half of the plant feed ends up in these scrap

fractions. The material which is recovered from the initial cell dismantling operation is 50 kilograms of polypropylene, 294 kilograms of steel scrap from the battery cases, 100 kilograms of electrolyte, and 60 kilograms of added water.

The remaining materials are essentially split between the hydride alloy and the nickel hydroxide electrodes. The nickel hydroxide electrode amounts to approximately 125 kilograms, all of which is sent to the leaching and electrowinning circuit. The hydride alloy electrode, containing the vanadium, chromium, titanium, and zirconium (or rare-earths in the case of $A B_{5}$ systems) along with nickel is milled and the nickel is separated producing approximately 131 kilograms of alloy for return to the battery alloy manufacturer. The nickel hydroxide is dissolved in hydrochloric acid in a similar way to the mixed feed described previously in Section 4.2. However, much less acid and a smaller tankhouse are required for nickel electrowinning. Essentially, the plant is handling about 25 percent of the feed of the mixedelectrode process described in Section 4.2.

\subsubsection{Design Considerations}

Leaching - The initial draining, hand separation, screening, and magnetic separation leaves only 13 percent of the initial feed, or approximately 0.54 metric tons per hour, of nickel hydroxide for leaching. If we allow for the same 8-hour leach cycle as we did for the mixedelectrode case, then our leacher would need to be capable of holding approximately 5,100 gallons of acid and 4.3 metric tons of scrap. If we flow liquid through the charge, we can design for a leacher of approximately $5 \mathrm{~m}^{3}(1,400 \mathrm{gal})$ and a storage tank of $25 \mathrm{~m}^{3}(7,000$ gallons). 
In view of the sizes given above, and to achieve added flexibility, it might be better to use two systems in parallel, each with vessels one-half as big. The leachers should be hard-rubberlined steel pressure vessels with tantalum-clad agitators, while the pumps, heat exchangers, and pipes which handle the $6 \mathrm{~N}$ hydrochloric acid should be tantalum or glass-lined steel. The associated large tanks, however, can be of glassed-steel construction, or other corrosionresistant materials capable of handling the high temperature of the leacher discharge, because they see no metallic solids.

Nickel Ėlectrowinning - The $\mathrm{AB}_{2}$ plant would produce approximately $278 \mathrm{~kg} / \mathrm{hr}(2,004$ metric tons per year) of cathode material. In our $\mathrm{AB}_{2}$ electrowinning step, the input nickel concentration to the cells is about $89 \mathrm{~kg} / \mathrm{m}^{3}$, which is almost double that of the Sumitomo plant described in Section 4.2. We could thus plan on also having a holdup of $0.80 \times(50 / 89) \times 168$ $=76 \mathrm{~m}^{3}$. We could achieve this by using 11 of the Sumitomo-sized $\left(7 \mathrm{~m}^{3}\right)$ cells. This part of the process would be operated continuously.

The chlorine produced as a by-product can be processed to recover hydrochloric acid for use in the leaching system, or the chlorine can simply be dried, compressed, and sold for by-product credit.

Waste Neutralization - This step is significantly reduced in size and complexity because of the removal of the hydride alloy from the circuit. The neutralization can now be done in a small tank on the order of 1,500 gallons. The slurry would be returned to the rotary filter for subsequent dewatering.

The waste solution in the is about 19 percent sodium and potassium chloride with a slight excess of sodium hydroxide. It also is assumed to contain all the additives which were in the cell electrolyte. If a desert location is assumed, it would be possible to spread this material out for solar evaporation to deposit dry salts (the sodium hydroxide would be changed by the carbon dioxide in the air to sodium carbonate). In the $\mathrm{AB}_{2}$ case, we would have to evaporate some 25,400 metric tons of water, or 21 acre-feet of water per year. In a location where net evaporation is, say, 60 inches per year, this would require a minimum land area of some 4.1 acres. The evaporation would deposit roughly $(19 / 81) \times 25,400=6,000$ metric tons of salts per year.

\subsection{Process Alternatives}

\subsubsection{Process Alternatives for $A B_{2}$ Systems}

The recovery of titanium and zirconium from the oxide form is extremely expensive and the market for these metals is very depressed, making it impossible to recover those materials economically based on current economic conditions. In addition, the long-term outlook for those metals, both highly dependent upon defense applications, makes it unlikely that it would be economic to recover them. The standard reduction process for those metals is the Kroll process, which begins with the chlorination of the oxide form of the metals. These chlorides are then reduced in the presence of magnesium or sodium to the metallic state. The separation of the titanium from the zirconium would be difficult. 


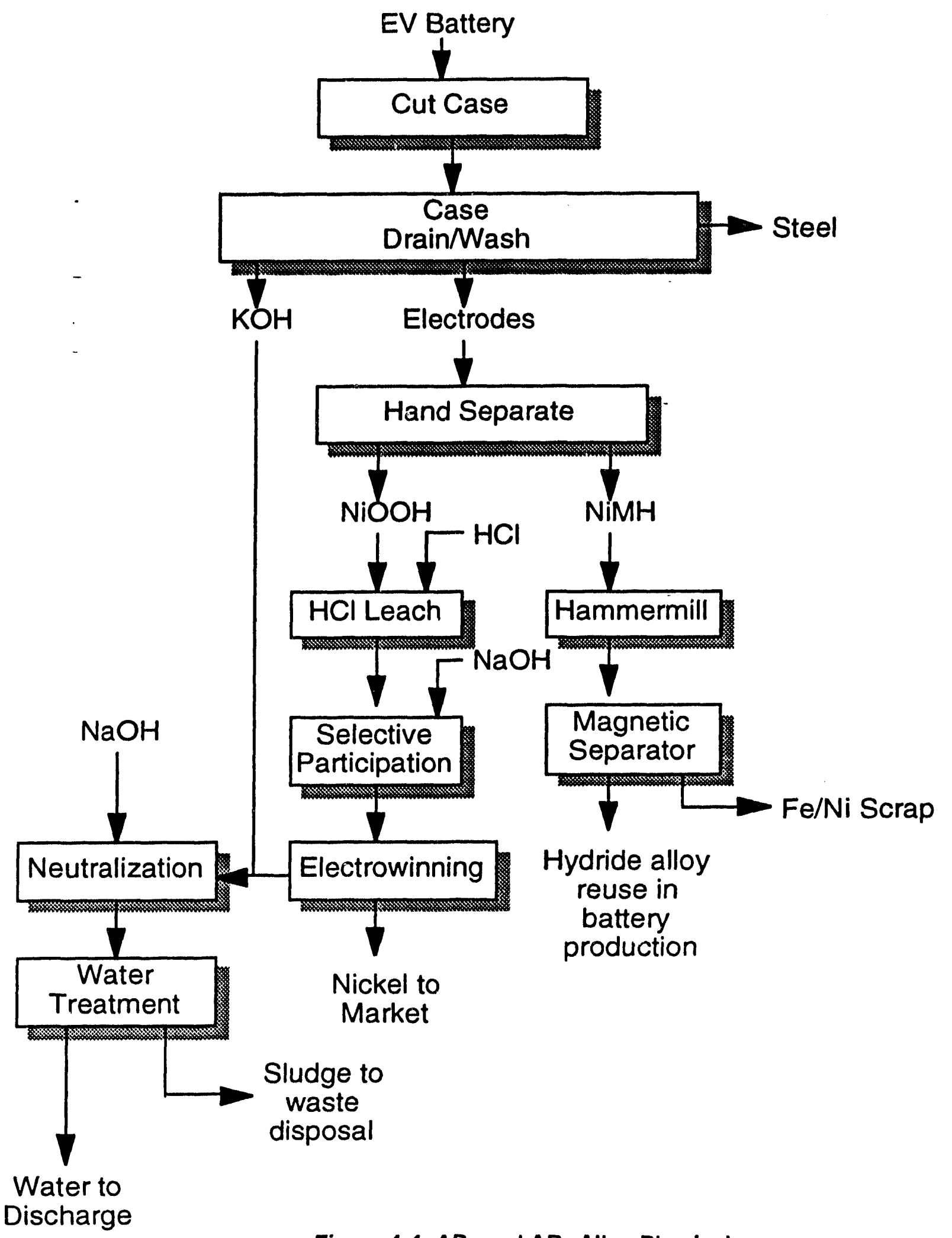

Figure 4-4: $A B_{2}$ and $A B_{5}$ Alloy Physical Separation/Chemical Process 
The other possible alternative for the recovery of the nickel values from the leaching processes would be to recover the nickel as a nickel carbonate precipitate. The sodium carbonate would be mixed into the nickel chloride solution, producing a nickel carbonate precipitate. The precipitate could then be sold for use by the nickel industry.

Leaching of the nickel metal hydride electrodes could also be done in sulfuric acid or nitric acid, but nickel chloride was chosen because of the capability to dispose of the salts generated and the ease of separation of the nickel and iron in solution.

\subsubsection{Process Options for $A B_{5}$ Systems}

Rare-earth oxides, silicates, and hydroxides are recovered by the nickel metal hydride reclaiming process discussed previously in this section of the report. It is desirable to attempt to recover those materials if possible in a form which is salable. However, after examining the process economics of rare-earth metal production, misch-metal production and rare-earth silicide production, it appears that none of these processes will be economically attractive for the recovery of the rare-earth values without significant capital recovery penalties at this scale of the operation. Therefore, these residues would best be marketed to rare-earth processors.

The other alternative is to produce misch-metal via the chlorination of the rare-earth oxides or hydroxides. The rare-earth slag would be difficult to dissolve in acid, but the addition of hydrofluoric acid may assist in the dissolution.

The rare-earth chlorides would be electrowon from molten rare earth chlorides. However, because of the current price of misch metal, it is unlikely that an electrowinning plant could be built to process the rare earths and produce any revenue. Therefore, we leave the recovery of the rare earths to a company with fully depreciated capital investment.

A final possible process would be to reduce the rare-earth slag in the presence of silicon metal to produce a rare-earth silicide for subsequent use as an alloying agent by the steel industry.

\subsubsection{Rare-Earth Production Process}

A short review of possible routes to recovering the rare-earth metals from the process residues is described below. There are three possible types of products; separated rare-earth metals (e.g., lanthanum metal, and cerium metal); misch-metal (the alloy of mixed rare earths); and rare-earth slicides (RESi) alloys.

The standard process for producing rare-earth metals is first to convert the rare earth containing ore to a fluoride compound by the dissolution of the ore in nitric acid followed by the addition of hydrofluoric acid. The rare-earth oxide is then precipitated and dried. A second approach is the reaction of rare-earth oxides with ammonium fluorohydride in a furnace to produce the fluoride. Other possible routes would be to react rare-earth oxides in a furnace with hydrogen fluoride gas.

The rare-earth fluorides are then recovered by molten salt electrolysis, producing metallic forms of the rare earths. A second approach would be a metallothermic reduction of the rare earths in the presence of sodium or calcium metal. 


\subsection{Capital and Operating Cost Comparisons}

Capital and operating cost (revenue) estimates were developed for each of the three processes described in Section 4 for the $A_{B}$ and $A B_{5}$ type nickel metal hydride $E V$ batteries.

\subsection{General Assumptions}

All process unit costs were estimated for locating the plant in southeastern California. Because of this assumption, several operating variables are considerably different from the national average. Energy costs were assumed to be $\$ 0.09 / \mathrm{Nm}^{3}$ for natural gas, and $\$ 0.09 / \mathrm{kWh}$ for electricity. Water was estimated at $\$ 1.00 / \mathrm{m}^{3}$. Disposal costs for solid wastes were estimated to be equal to zero because it is unclear if most of the solid wastes generated at the plant could be sold as a low-value product. Hazardous waste disposal was estimated to be $\$ 400$ per metric ton. The costs for process chemicals were obtained from vendor quotes and Chemical Marketing Reporter, the by-product values were obtained from vendor quotations, and spot price estimates from American Metal Market and Plastics News.

Many of the operating cost assumptions were obtained from the Arthur D. Little database of process cost data. The data has been obtained from numerous sources. The specific sources of the data are not available due to the utilization of average values from general sources. Some of the data has been taken from other cost models developed from similar installations, or for similar geographic locations.

Labor costs were estimated at $\$ 15.75$ per hour for operations and maintenance labor. Benefits were estimated at 35 percent of the operating and maintenance labor.

Other variable annual costs such as maintenance materials were estimated at 5 percent of total capital investment, and operating supplies were estimated at 10 percent of operating labor cost. Transportation costs were estimated at $\$ 50$ per ton of batteries shipped to the plant. Fixed plant costs were estimated based on typical cost factors used in study estimates. General plant overhead was estimated at 60 percent of total labor cost. Storage costs at plant site are included as part of general plant overhead. Off-site storage was considered part of transportation cost. Annual insurance and property taxes were estimated at 2 percent of total investment.

Depreciation of plant equipment and buildings was taken as a simple straight line schedule of 10 years. Interest expense was estimated as the discounted cash flow over a 15-year period at an interest rate of 7 percent financing the plant.

The EV batteries were assumed to be acquired for no cost, although as shown later in this section, a cost of acquisition may be necessary due to the inherent value of the batteries. Byproduct credits were estimated at current market prices of similar products and residues. Credits were discussed with producers and buyers of metals and residues.

Capital costs were estimated from vendor quotations of major capital equipment and by the application of scaling factors and cost estimate tables and equations published in several sources, including Chemical Engineering (Guthrie, 1969; Hall, 1988; Feldman, 1969) and publications of the Canadian Institute of Mining and Metallurgy (Mular, 1982).

Installation costs for the various process equipment were based on vendor quotations and on installation cost factors such as those described by Guthrie (Guthrie, 1969). To determine the total investment in the process, the following assumptions were made: 
- the cost of project offsites (e.g., waste-disposal sites, steam-generation plants, cooling towers, laboratories, and auxiliary facilities) was estimated at 30 percent of the installed process equipment costs;

- the cost of utilities (e.g., substations, gas-main extensions, distribution centers, fire protection) was estimated at 15 percent of the process equipment costs;

- site preparation cost was estimated at 4 percent of the total process equipment cost, and land cost was estimated at $\$ 20,000$ per acre based on a quotation of industrial land currently available in the Bakersfield area for industrial development;

- building costs were estimated at $\$ 40$ per square foot;

- the cost of environmental permit application including consulting and legal fees was estimated at $\$ 1,000,000$;

- the cost of engineering design was estimated at 10 percent of the total process equipment costs;

- startup costs were estimated at 10 percent of the capital investment, and included such items as working capital, labor training, initial chemicals, and other similar costs; and

- a contingency of 15 percent of the total investment (process equipment and indirect costs) was included.

\subsection{Capital Investment and Operating Cost for $A B_{2}$ Processing Plants}

The capital investment at the $\mathrm{AB}_{2}$ processing plant, including materials preparation for the leaching, electrowinning, waste neutralization, and disposal, was $\$ 42.6$ million for the 30,000 metric-tons-per-year plant. The details of the capital cost estimate are shown in Table 5-1. The operating cost of the plant was $\$ 12.59$ per EV battery, or $\$ 0.16 / \mathrm{kWh}$ of EV. The details of the operating revenue are shown in Table 5-2.

The capital investment at the $\mathrm{AB}_{2}$ processing plant, including materials preparation for the pyrometallurgical process, smelting, refining, waste neutralization, and disposal, was $\$ 46.5$ million for the 30,000 metric-tons-per-year plant. The details of the capital cost estimate are shown in Table 5-3. The operating revenue of the plant was $\$ 195.73$ per EV battery, or $\$ 2.45 / \mathrm{kWh}$ of EV. The details of the operating revenue are shown in Table 5-4.

The capital investment for the physical separation and chemical process at the $\mathrm{AB}_{2}$ processing plant including materials preparation, leaching, electrowinning, waste neutralization, and disposal, was $\$ 23.3$ million for the 30,000-metric-ton-per-year plant. The details of the capital cost estimate are shown in Table 5-5. The operating revenue of the plant was $\$ 480.74$ per EV battery, or $\$ 6.01 / \mathrm{kWh}$ of EV. The details of the operating revenue are shown in Table 5-6.

\subsection{Capital Investment and Operating Costs for $\mathrm{AB}_{5}$ Processing Plants}

The capital investment at the chemical process at the $\mathrm{AB}_{5}$ processing plant, including materials preparation, leaching, electrowinning, waste neutralization, and disposal, was $\$ 35.9$ million for the 30,000-metric-tons-per-year plant. The details of the capital cost estimate are shown in Table 5-7. The operating revenue of the plant was $\$ 246.95$ per EV battery, or $\$ 3.09 / \mathrm{kWh}$ of EV. The details of the operating revenue are shown in Table 5-8. 
Table 5-1. $A B_{2}$ alloy chemical process capital cost estimate

\begin{tabular}{|c|c|c|c|c|c|c|}
\hline Process Equipment & Number & $\begin{array}{c}\text { Purchase } \\
\text { Cost }\end{array}$ & $\begin{array}{l}\text { Total Process } \\
\text { Equipment } \\
\text { Cost }\end{array}$ & $\begin{array}{c}\text { Instaliation } \\
\text { Factor }\end{array}$ & $\begin{array}{l}\text { Tolal } \\
\text { Inslalied } \\
\text { Cost }\end{array}$ & Description \\
\hline $\begin{array}{l}\text { Cell Dralner } \\
\text { Cell Case Remover } \\
\text { Knile Mill } \\
\text { Shredder } \\
\text { Screen } \\
\text { Magnetlc Separator } \\
\text { Leacher } \\
\text { Mixer Tantalum } \\
\text { Acld Storage Tank } \\
\text { MixerSettlers } \\
\text { Precipitalor } \\
\text { Rotary Filter } \\
\text { Tankhouse } \\
\text { Waste Neutralizers } \\
\text { Thickener } \\
\text { Evaporatlon Pond } \\
\text { Hydrogen Flare } \\
\text { Conveyors } \\
\text { Pumps } \\
\text { Pumps } \\
\text { Cranes } \\
\text { Feeders } \\
\text { Heat Exchangers } \\
\text { Heat Exchangers } \\
\text { Acid Storage Tank } \\
\text { Caustic Slorage Tank }\end{array}$ & $\begin{array}{r}1 \\
1 \\
1 \\
1 \\
1 \\
2 \\
2 \\
2 \\
4 \\
2 \\
1 \\
1 \\
2 \\
1 \\
1 \\
1 \\
10 \\
8 \\
10 \\
2 \\
6 \\
2 \\
6 \\
3 \\
2\end{array}$ & $\begin{array}{r}\$ 20,000 \\
\$ 20,000 \\
\$ 47,000 \\
\$ 25,003 \\
\$ 6,269 \\
\$ 25,200 \\
\$ 480,866 \\
\$ 37,192 \\
\$ 107,446 \\
\$ 30,586 \\
\$ 57,046 \\
\$ 94,297 \\
\$ 1,403,031 \\
\$ 57,046 \\
\$ 308,232 \\
\$ 4,000,000 \\
\$ 50,000 \\
\$ 10,030 \\
\$ 68,956 \\
\$ 5,000 \\
\$ 139,501 \\
\$ 11,346 \\
\$ 60,000 \\
\$ 15,000 \\
\$ 204,918 \\
\$ 204,918\end{array}$ & $\begin{array}{r}\$ 20,000 \\
\$ 20,000 \\
\$ 47,000 \\
\$ 25,000 \\
\$ 6,260 \\
\$ 25,200 \\
\$ 861,732 \\
\$ 74,384 \\
\$ 214,893 \\
\$ 122,346 \\
\$ 114,091 \\
\$ 94,297 \\
\$ 1,403,031 \\
\$ 114,091 \\
\$ 308,232 \\
\$ 4,000,000 \\
\$ 50,000 \\
\$ 100,300 \\
\$ 551,650 \\
\$ 50,000 \\
\$ 279,002 \\
\$ 68,079 \\
\$ 120,000 \\
\$ 90,000 \\
\$ 614,754 \\
\$ 409,836 \\
\end{array}$ & $\begin{array}{r}2.5 \\
2.5 \\
2.5 \\
2.5 \\
2.32 \\
2.5 \\
4.34 \\
1.5 \\
3.29 \\
3.29 \\
3.29 \\
2.6 \\
1 \\
3.29 \\
3.29 \\
1 \\
3 \\
2.69 \\
3.48 \\
3.48 \\
1.6 \\
2.3 \\
2.7 \\
3.39 \\
3.29 \\
3.29 \\
\end{array}$ & $\begin{array}{r}\$ 50,000 \\
\$ 50,000 \\
\$ 117,500 \\
\$ 62,500 \\
\$ 14,544 \\
\$ 63,001 \\
\$ 4,173,915 \\
\$ 111,576 \\
\$ 706,097 \\
\$ 402,518 \\
\$ 375,360 \\
\$ 245,172 \\
\$ 1,403,031 \\
\$ 375,360 \\
\$ 1,014,083 \\
\$ 4,000,000 \\
\$ 150,000 \\
\$ 269,807 \\
\$ 1,919,742 \\
\$ 174,000 \\
\$ 446,403 \\
\$ 156,581 \\
\$ 324,000 \\
\$ 305,100 \\
\$ 2,022,541 \\
\$ 1,348,360\end{array}$ & 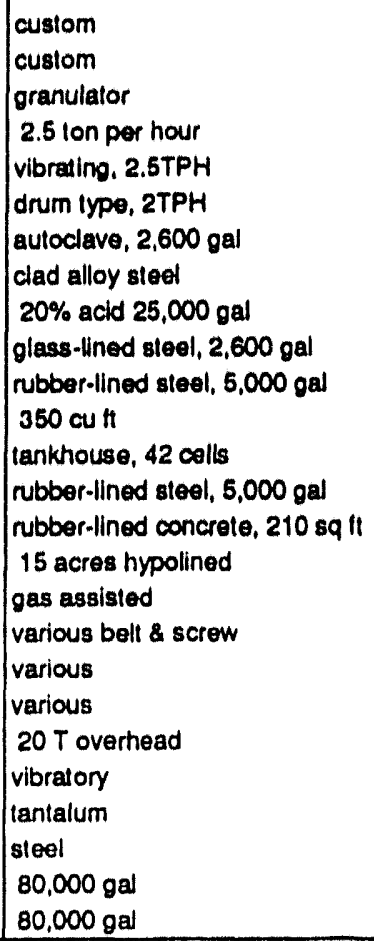 \\
\hline \multicolumn{3}{|c|}{ Tolal Process Equipment (Battery Limit) } & $\$ 9,884,187$ & & $\$ 20,282,092$ & \\
\hline
\end{tabular}

\begin{tabular}{|l|r|c|}
\hline Cost hem & $\begin{array}{c}\text { Tolal Cost } \\
1993 \$\end{array}$ & Basis \\
\hline Process Equipment & $\$ 20,282,092$ & \\
OHisites & $\$ 6,084,628$ & $@ 30 \%$ PE \\
Utilities & $\$ 3,042,314$ & $@ 15 \%$ PE \\
\hline Tolal Plant Equipment & $\$ 26,366,720$ & \\
\hline Sile Preparation & $\$ 811,284$ & $@ 4 \%$ PE \\
Land Acquisition & $\$ 1,000,000$ & $@ \$ 20,000 /$ acre \\
Buildings & $\$ 2,000,000$ & 50,000 sq H \\
Permits & $\$ 1,000,000$ & \\
Engineering & $\$ 2,940,903$ & $@ 10 \%$ TPE \\
Startup Cost & $\$ 2,940,903$ & $@ 10 \%$ TPE \\
\hline Indirect Costs & $\$ 10,693,090$ & \\
\hline Contingency & $\$ 5,558,971$ & $@ 15 \%$ TPE+IC \\
\hline Tolal Installed Cost & $\$ 42,618,781$ & \\
\hline
\end{tabular}


Table 8-2: AB2 Alloy Chemical Process Operating Cost Estimate

Production (Feed) $\quad 30,000 \quad$ tons/year

\begin{tabular}{|c|c|c|c|c|c|c|c|}
\hline & & $\begin{array}{c}\text { Consumption/ } \\
\text { ton Feed }\end{array}$ & Cost/Unit & $\begin{array}{l}\text { Costiton } \\
\text { Feed }\end{array}$ & Unit/Year & Cost & $\begin{array}{l}\text { CosteV } \\
\text { Batiery }\end{array}$ \\
\hline ARLABLE OPBRA & ? & $08+4+30$ & 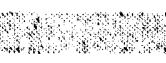 & mon & & & \\
\hline RAWMATERIALS & Unit & Unitton Feed & s/Unit & Ston Feed & tons & $000 \mathrm{~s}$ & S/Battery \\
\hline Batteries & $\mathrm{kg}$ & 1000.00 & 0.00 & 0.00 & 30,000 & 0 & 0.00 \\
\hline $\begin{array}{l}\mathrm{HCl}(35 \% \text { aqueous) } \\
\mathrm{NaOH} \text { ( } 50 \% \text { aqueous) }\end{array}$ & $\begin{array}{l}\mathrm{kg} \\
\mathrm{kg}\end{array}$ & $\begin{array}{l}1439.71 \\
864.00\end{array}$ & $\begin{array}{l}0.06 \\
0.33\end{array}$ & $\begin{array}{c}87.30 \\
285.77\end{array}$ & $\begin{array}{l}43,191 \\
25,920\end{array}$ & $\begin{array}{l}2,619 \\
8,573\end{array}$ & $\begin{array}{l}28.37 \\
92.87\end{array}$ \\
\hline $\mathrm{NaOCl}$ (9\% aqueous) & kg & 362.22 & 0.46 & 0.17 & 10,867 & 5 & 0.05 \\
\hline
\end{tabular}

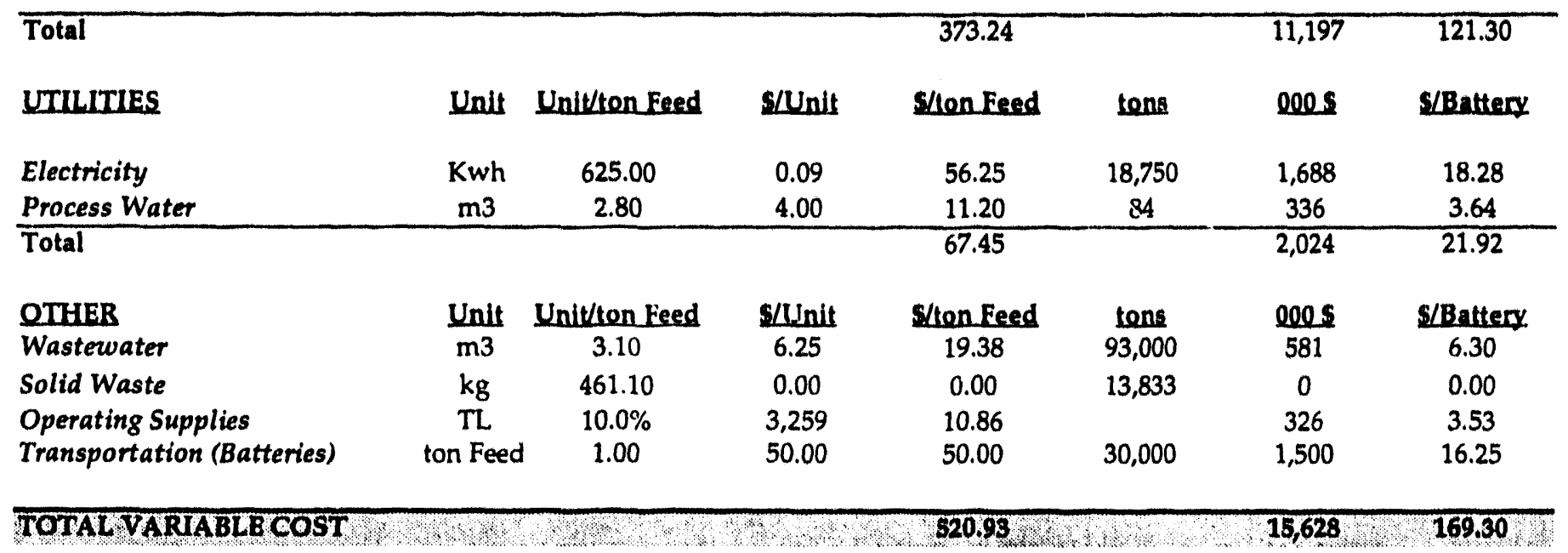

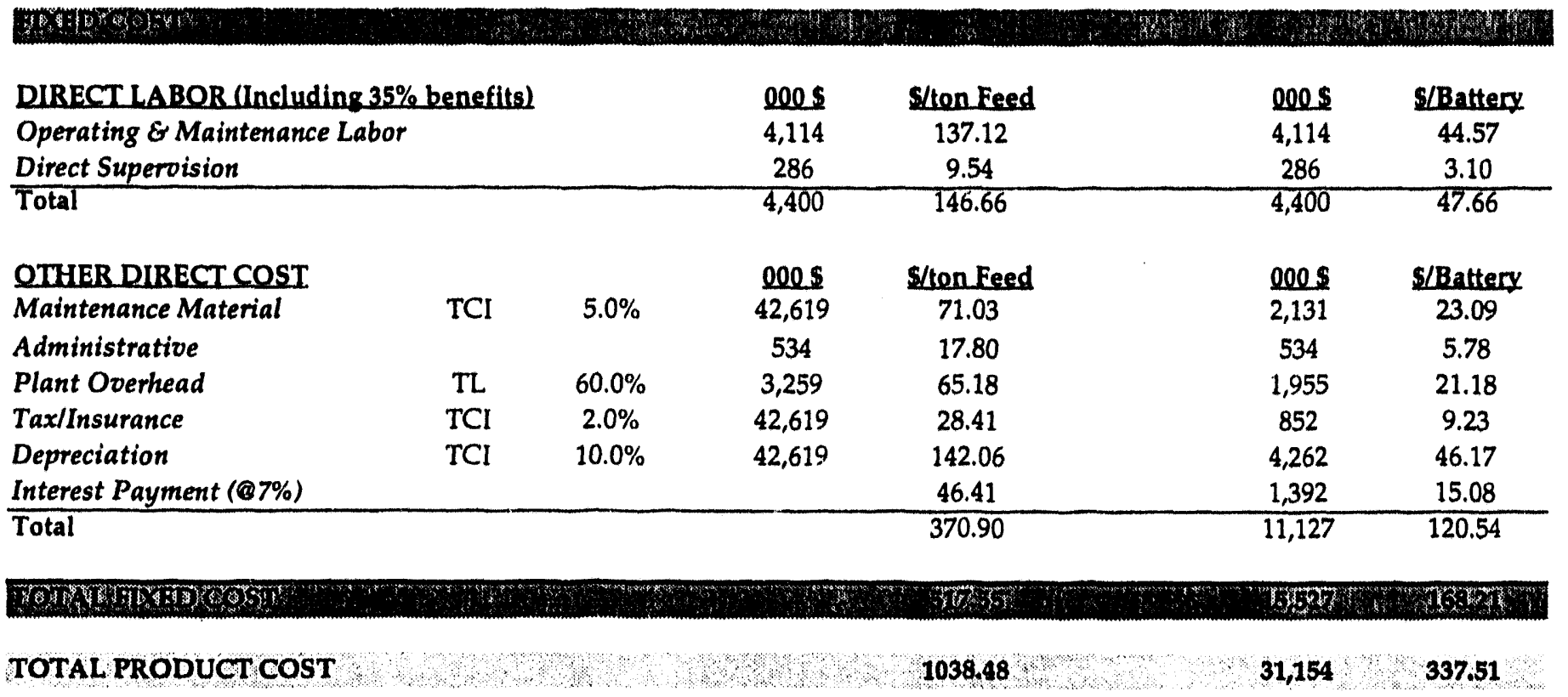


Table 5-2. AB2 Alloy Chemical Proceses Operating Cost Estimate

Production (Feed) $\quad 30,000 \quad$ tons/year

BY-PRODUCT CREDITS

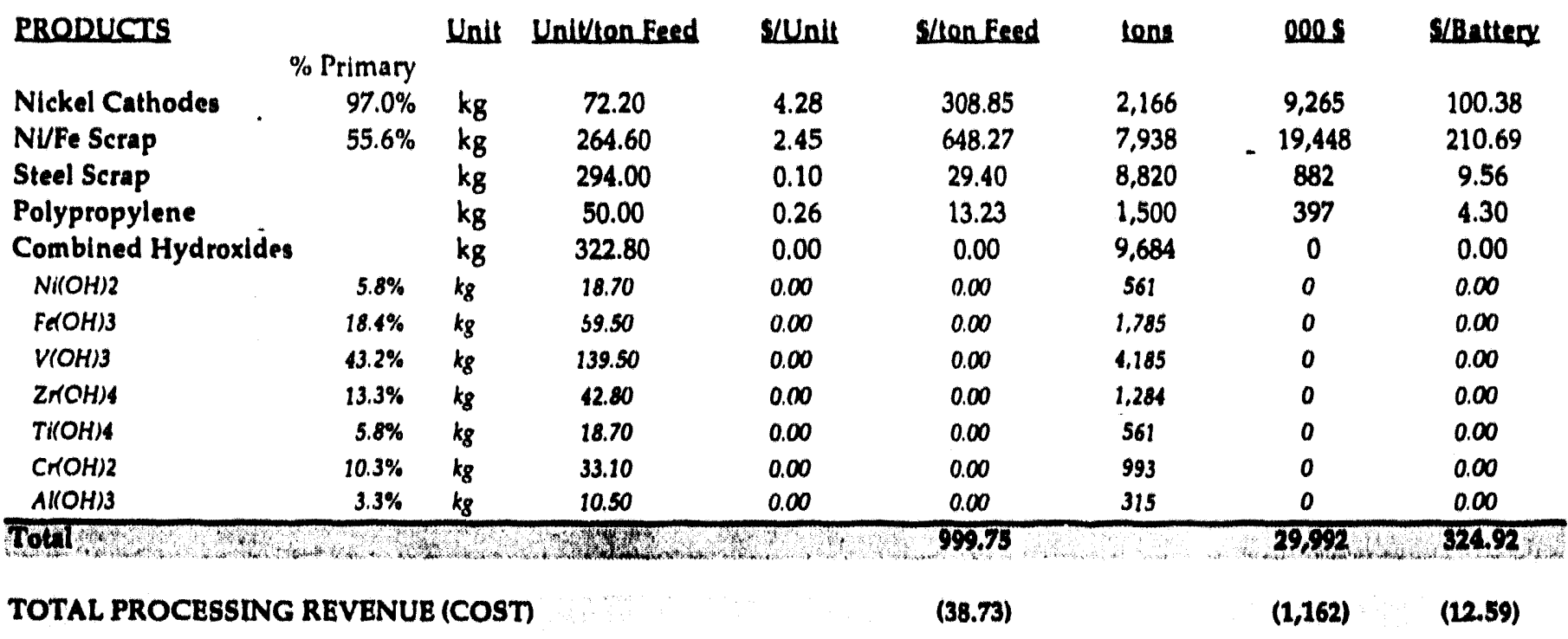


Table 8-2. AB2 Alloy Chemleal Process Operating Coot Eotimate

\begin{tabular}{|c|c|c|c|c|c|}
\hline Labor Category & $\begin{array}{c}\text { "of } \\
\text { Shifts }\end{array}$ & $\begin{array}{l}\text { Persons } \\
\text { Per Shift }\end{array}$ & $\begin{array}{c}\text { Total } \\
\text { Pereons }\end{array}$ & $\begin{array}{l}\text { Salary } \\
\text { S/Year }\end{array}$ & Total S/Year \\
\hline \multicolumn{6}{|l|}{ Dpernton } \\
\hline Process & 4.0 & 16 & 64.0 & 32,760 & $2,096,640$ \\
\hline Maintenance & 4.0 & 5 & 20.0 & 32,760 & 655,200 \\
\hline \multirow[t]{2}{*}{ Eoremnn } & 4.0 & 2 & 8.0 & 36,920 & 295,360 \\
\hline & & & & Subtotal & $3,047,200$ \\
\hline \multicolumn{6}{|l|}{ Superriten } \\
\hline Production Supervisor & 1.0 & 1.0 & 1.0 & 44,402 & 44,402 \\
\hline Uttlitles Engineers & 1.0 & 1.0 & 1.0 & 39,382 & 39,382 \\
\hline Facilities Enginears & 1.0 & 2.0 & 2.0 & 42,998 & 85,996 \\
\hline \multirow[t]{2}{*}{ Maintenance Supervisor } & 1.0 & 1.0 & 1.0 & 42,120 & 42,120 \\
\hline & & & & Subtotal & 211,900 \\
\hline \multicolumn{6}{|l|}{ Adminiatrative } \\
\hline Plant Manager & 1.0 & 1.0 & 1.0 & 87,750 & 87,750 \\
\hline Chemist & 1.0 & 2.0 & 2.0 & 51,055 & 102,109 \\
\hline Controller & 1.0 & 1.0 & 1.0 & 44,460 & 44,460 \\
\hline Clerk & 1.0 & 1.0 & 1.0 & 24,570 & 24,570 \\
\hline Secretary & 1.0 & 1.0 & 1.0 & 21,060 & 21,060 \\
\hline Nurse & 1.0 & 1.0 & 1.0 & 30,420 & 30,420 \\
\hline \multirow[t]{2}{*}{ Security } & 4.0 & 1.0 & 4.0 & 21,294 & 85,176 \\
\hline & & & & Subtotal & 395,545 \\
\hline \multicolumn{2}{|l|}{ Total Labor } & & 108.1 & & $3,654,645$ \\
\hline \multicolumn{5}{|c|}{ Total EmployeedLabor Cost (with 35\% benefito) } & $4,933,771$ \\
\hline
\end{tabular}

Sensitivity Analyols:

\begin{tabular}{|l|c|ccccc|}
\hline \multicolumn{1}{|c|}{ Scenario } & Unit & Base & High & Cost & Price Low & Process Cost \\
\hline By-Product & Mattery & $(12.59)$ & & 990.16 & & $(22.87)$ \\
Nickel Cathodes & //b Ni & 2.00 & 8.43 & & 1.95 & \\
$\mathrm{Ni} /$ Fe Scrap & $\$ / 16 \mathrm{Ni}$ & 2.00 & 8.43 & & 1.95 & \\
Steel Scrap & $5 / g r o s s t o n$ & 100.00 & 128.00 & & 73.72 & \\
\hline Capital Investment & Smm & 42.62 & 49.01 & $(26.62)$ & 36.23 & 1.45 \\
Interest Payment & $\%$ & $7.0 \%$ & $12.0 \%$ & $(23.36)$ & $7.0 \%$ & $(12.59)$ \\
Electricity & $\$ / K w h$ & 0.09 & 0.12 & $(18.68)$ & 0.05 & $(4.46)$ \\
\hline
\end{tabular}


Table 5-3. $A B_{2}$ alloy pyrometallurgical procese capital cost estimato

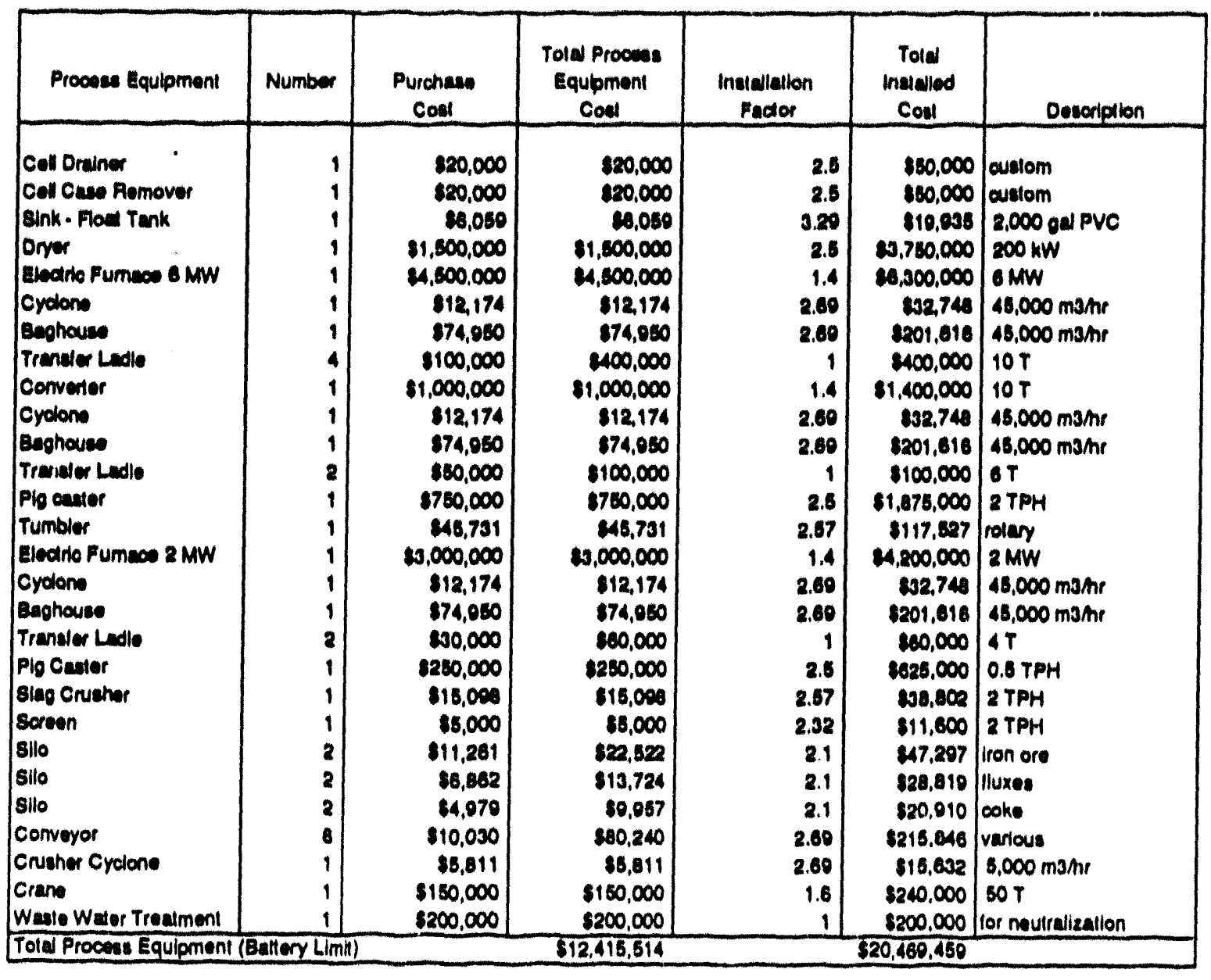

\begin{tabular}{|c|c|c|}
\hline Coul hem & $\begin{array}{c}\text { Tolal Coul } \\
1000 \mathrm{~s}\end{array}$ & Basis \\
\hline Proceses Equipment & $\$ 20,460,450$ & \\
\hline OHalles & $86,140,838$ & (10\% PE \\
\hline Uillinies & $\$ 3,070,410$ & C16\% PE \\
\hline Told Planl Equipment & $\$ 29,680,715$ & \\
\hline Slie Preparation & 8818.778 & DA\%PE \\
\hline Land Acquilition & $\$ 1,000,000$ & (1) $\$ 20,000$ / acre \\
\hline Building & $\$ 2,000,000$ & $50,000 \mathrm{sq} \mathrm{H}$ \\
\hline Pormits & $\$ 1,000,000$ & \\
\hline Engineering & $\$ 2,068,072$ & (910\% TPE \\
\hline sientup cosi & $82,068,072$ & Q10\% TPE \\
\hline Indireac Costs & $\$ 10,754,221$ & \\
\hline Conlingency & $\$ 6,065,346$ & Q15\% TPE + $1 \mathrm{C}$ \\
\hline Told Installed Cost & $\$ 46,500,082$ & \\
\hline
\end{tabular}


Table 8-4. AB2 Alloy Pyrometallurgleal Procose Oporalling Cost Eatimate

Production (Feed) $\quad 30,000 \quad$ tons/year

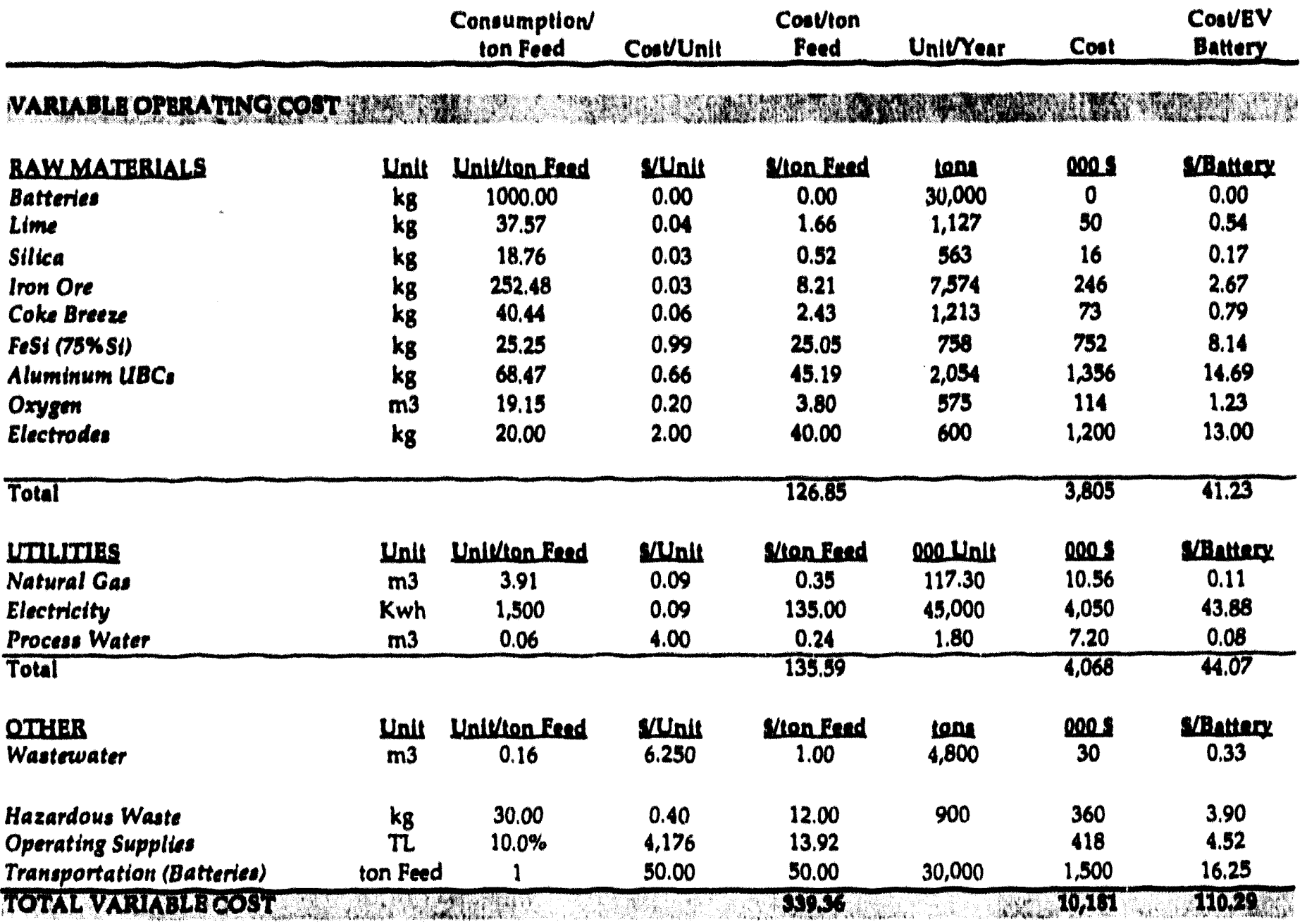

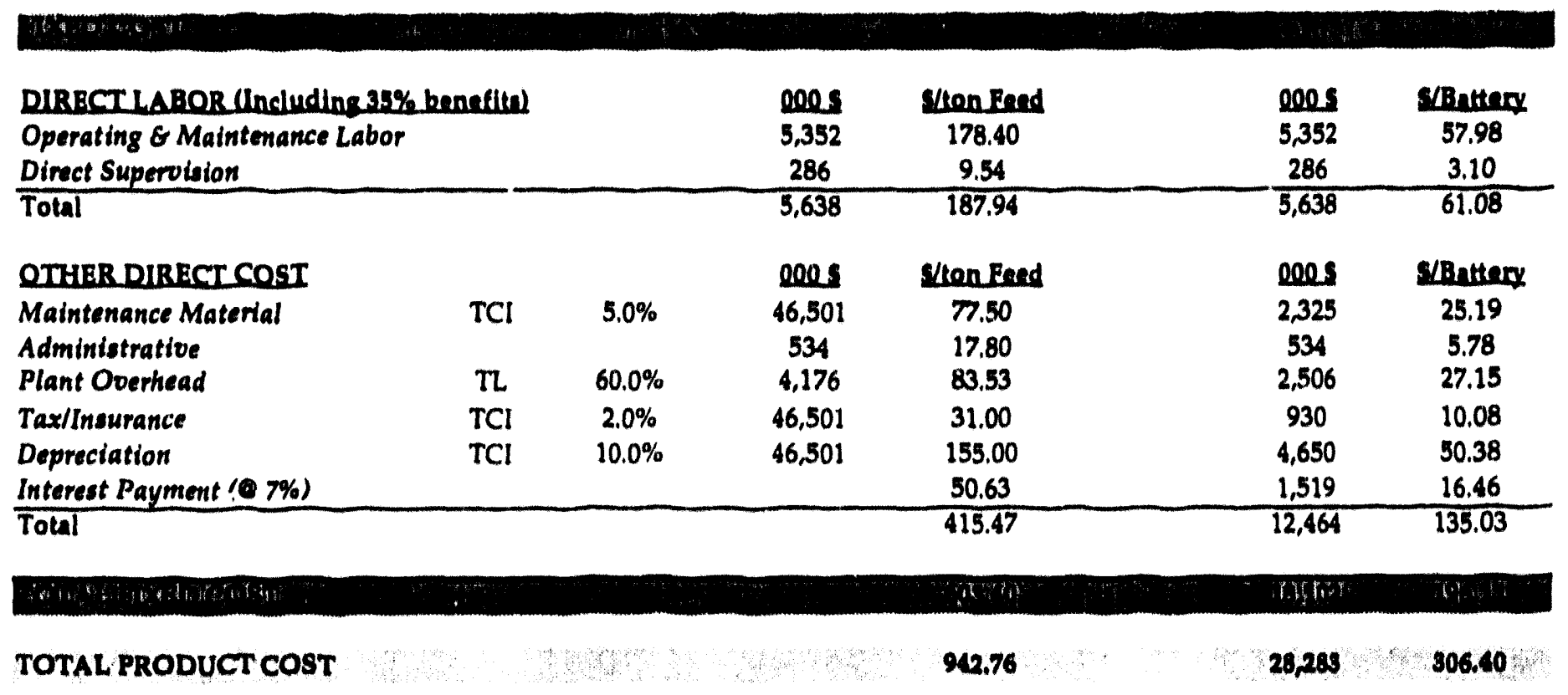


Table 84. AB2 Alloy Pyromotallurgleal Prosess Operating Cost Eotimate

Production (Feed) $\quad 30,000 \quad$ Ions/year

\section{BY-PRODUCT CREDITS}

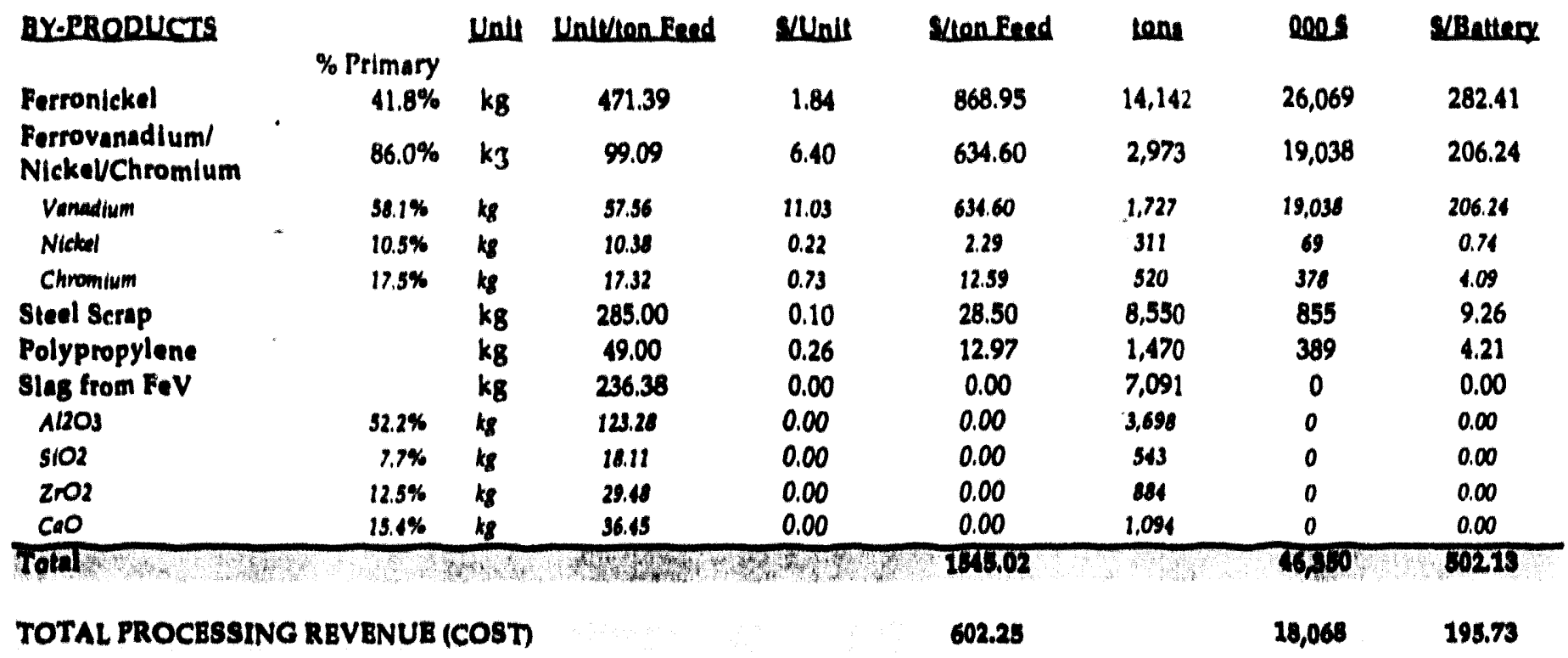




\begin{tabular}{|c|c|c|c|c|c|}
\hline Labor Category & $\begin{array}{c}\text { of of } \\
\text { Shifts }\end{array}$ & $\begin{array}{l}\text { Persolus } \\
\text { Per Shift }\end{array}$ & $\begin{array}{c}\text { Total } \\
\text { Persons }\end{array}$ & $\begin{array}{l}\text { Salary } \\
\text { S/Year }\end{array}$ & Total $\$ /$ Year \\
\hline \multicolumn{6}{|l|}{ Opernion } \\
\hline Process & 4.0 & 23 & 92.0 & 32,760 & $3,013,920$ \\
\hline Maintenance & 4.0 & 5 & 20.0 & 32,760 & 655,200 \\
\hline Boremen & 4.0 & 2 & 8.0 & $\frac{36,920}{\text { Subtotat }}$ & $\begin{array}{r}295,360 \\
3,964,480\end{array}$ \\
\hline \multicolumn{6}{|l|}{ Siunondion } \\
\hline Production Supervicor & 1.0 & 1.0 & 1.0 & 44,402 & 44,402 \\
\hline Utllites Bngineers & 1.0 & 1.0 & 1.0 & 39,382 & 39,382 \\
\hline Fadlltes Engtheers & 1.0 & 2.0 & 2.0 & 42,998. & 85,996 \\
\hline Maintenance Supervisor & 1.0 & 1.0 & 1.0 & 42,120 & 42,120 \\
\hline & & & & Subtotal & 211,900 \\
\hline \multicolumn{6}{|l|}{ Adminintrative } \\
\hline Plant Manager & 1.0 & 1.0 & 1.0 & 87,750 & 87,750 \\
\hline Chemilst & 1.0 & 2.0 & 2.0 & 51,055 & 102,109 \\
\hline Controller & 1.0 & 1.0 & 1.0 & 44,460 & 44,460 \\
\hline Clerk & 1.0 & 1.0 & 1.0 & 24,570 & 24,570 \\
\hline Secretary & 1.0 & 1.0 & 1.0 & 21,060 & 21,060 \\
\hline Nurse & 1.0 & 1.0 & 1.0 & 30,420 & 30,420 \\
\hline \multirow[t]{2}{*}{ Security } & 4.0 & 1.0 & 4.0 & 21,294 & 85,176 \\
\hline & & & & Subtotal & 395,545 \\
\hline Total Labor & & & 136.0 & & 4,571,925 \\
\hline \multicolumn{5}{|l|}{ Total Bmployeed/Labor Co } & $6,172,099$ \\
\hline
\end{tabular}

Senaltivity Analyole:

\begin{tabular}{|c|c|c|c|c|c|c|}
\hline Scenario & Un't & Base & High & Cost & Price Low & Process Cost \\
\hline $\begin{array}{l}\text { By-Product } \\
\text { Ferronickel } \\
\text { Ferrovanadium } \\
\text { Ferrovanadium (V) } \\
\text { Ferrovanadium (Ni) } \\
\text { Steel Scrap }\end{array}$ & 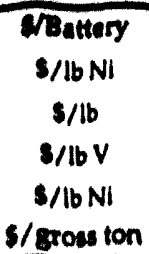 & $\begin{array}{c}195.73 \\
2.00 \\
6.63 \\
5.00 \\
0.10 \\
100.00\end{array}$ & $\begin{array}{c}8.43 \\
24.53 \\
18.50 \\
0.42 \\
128.00\end{array}$ & 1663.13 & $\begin{array}{c}1.95 \\
6.63 \\
5.00 \\
0.10 \\
73.72\end{array}$ & 186.24 \\
\hline $\begin{array}{l}\text { Capital Investment } \\
\text { Interest Payment } \\
\text { Electricity }\end{array}$ & $\begin{array}{c}3 \mathrm{~mm} \\
\% \\
\$ / K w h\end{array}$ & $\begin{array}{l}46.50 \\
7.0 \% \\
0.09\end{array}$ & $\begin{array}{c}53.48 \\
12.0 \% \\
0.12\end{array}$ & $\begin{array}{l}180.42 \\
183.98 \\
181.11\end{array}$ & $\begin{array}{l}39.53 \\
7.0 \% \\
0.05\end{array}$ & $\begin{array}{l}211.05 \\
195.73 \\
215.23\end{array}$ \\
\hline
\end{tabular}


Table 5-5. $A B_{2}$ alloy physical separation/chemical process capital cost estimate

\begin{tabular}{|c|c|c|c|c|c|c|}
\hline Process Equlpment & Number & $\begin{array}{c}\text { Purcheses } \\
\text { Cout }\end{array}$ & $\begin{array}{c}\text { Total Proceat } \\
\text { Equipment } \\
\text { Coul } \\
\end{array}$ & $\begin{array}{c}\text { Insiallation } \\
\text { Factor }\end{array}$ & $\begin{array}{l}\text { Told } \\
\text { Inslalled } \\
\text { Cost }\end{array}$ & Descripiton \\
\hline 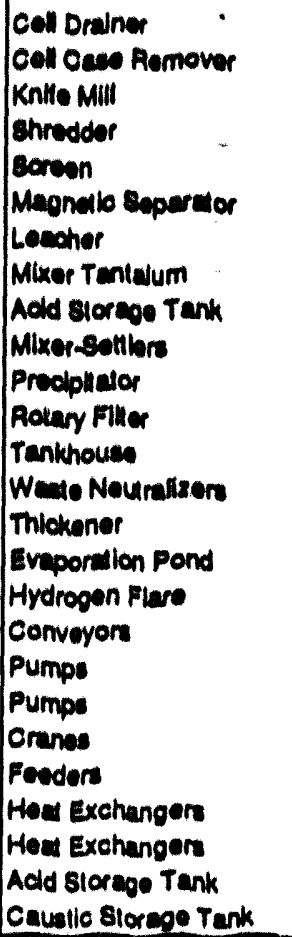 & $\begin{array}{r}1 \\
1 \\
1 \\
1 \\
2 \\
2 \\
2 \\
2 \\
2 \\
1 \\
1 \\
1 \\
1 \\
2 \\
1 \\
1 \\
1 \\
10 \\
6 \\
10 \\
2 \\
6 \\
2 \\
6 \\
1 \\
1\end{array}$ & 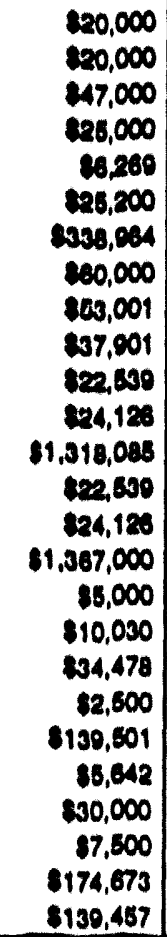 & 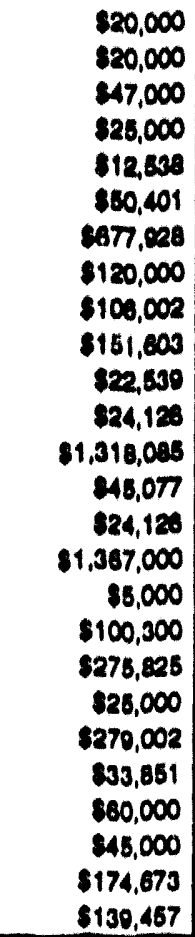 & $\begin{array}{r}2.5 \\
2.5 \\
2.5 \\
2.5 \\
2.32 \\
2.5 \\
4.34 \\
1.6 \\
3.20 \\
3.20 \\
3.20 \\
2.6 \\
1 \\
3.20 \\
3.20 \\
1 \\
3 \\
2.60 \\
3.48 \\
3.48 \\
1.6 \\
2.3 \\
2.7 \\
3.30 \\
3.20 \\
3.20\end{array}$ & 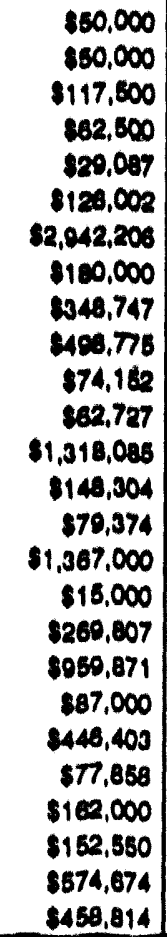 & 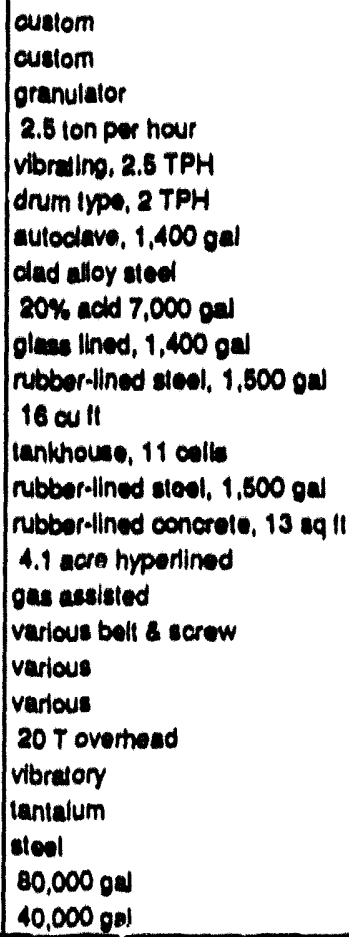 \\
\hline \multicolumn{3}{|c|}{ Total Process Equipment (Batiery Limil) } & $35,160,532$ & & $\$ 10,658,437$ & \\
\hline
\end{tabular}

\begin{tabular}{|c|c|c|}
\hline Coet hem & $\begin{array}{c}\text { Total Cost } \\
1000 \text { s }\end{array}$ & Basis \\
\hline $\begin{array}{l}\text { Procenes Equlpmont } \\
\text { Ollates } \\
\text { Utillites }\end{array}$ & $\begin{array}{r}\$ 10,658,407 \\
\$ 5,107,531 \\
\$ 1,898,768\end{array}$ & $\begin{array}{l}\text { (15\% PE } \\
15 \% \text { PE }\end{array}$ \\
\hline Totel Plant Equpment & $\$ 13,865,068$ & \\
\hline Sho Preparation & 348,337 & (14\% PE \\
\hline $\begin{array}{l}\text { Lend Aequilition } \\
\text { Bulleting }\end{array}$ & $\begin{array}{r}\$ 700,000 \\
\$ 1,000,000\end{array}$ & $\begin{array}{c}\text { (1) } \$ 20,000 / \text { acte } \\
30,000 \text { th }\end{array}$ \\
\hline Pormile & $\$ 1,000,000$ & \\
\hline Englneering & $\$ 1,545,473$ & (10\% TPE \\
\hline Siartup cost & $\$ 1,845,473$ & (10\% TPE \\
\hline Indireat Costs & $\$ 6,417,284$ & \\
\hline Contingenoy & $\$ 3,040,088$ & Q15\% TPE+1C \\
\hline Tolal installod Cost & $\$ 23,314,241$ & \\
\hline
\end{tabular}


Table 8-8. AB2 Alloy Phyaloal separationChemical Procese Operating Cost Estimate

Production (Feed) $\quad 30,000 \quad$ Ions/year

\begin{tabular}{|c|c|c|c|c|c|c|c|}
\hline & & $\begin{array}{c}\text { Consumption } \\
\text { Ion Feed }\end{array}$ & Cosvunil & $\begin{array}{c}\text { Costion } \\
\text { Feed }\end{array}$ & Unieryear & Cost & $\begin{array}{l}\text { Cost/EV } \\
\text { Batlery }\end{array}$ \\
\hline VARA ABE OPERA & $+\infty$ & 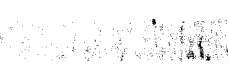 & & of & & & W \\
\hline RAWMATIERIALS & Unil & Univiton Feed & sunit & ston Feed & Lon: & $000 \mathrm{~s}$ & Shitiery \\
\hline $\begin{array}{l}\text { Batteries } \\
\text { HCl (35\% aqueous) }\end{array}$ & $\begin{array}{l}\mathbf{k g}_{8} \\
\mathbf{k g}_{8}\end{array}$ & $\begin{array}{l}1000.00 \\
350.86\end{array}$ & $\begin{array}{l}0.00 \\
0.06\end{array}$ & $\begin{array}{c}0.00 \\
21.28\end{array}$ & $\begin{array}{l}30,000 \\
10,526\end{array}$ & $\begin{array}{c}0 \\
638\end{array}$ & $\begin{array}{l}0.00 \\
6.91\end{array}$ \\
\hline
\end{tabular}

\begin{tabular}{|c|c|c|c|c|c|c|c|}
\hline Total & & & & 92.39 & & 2,772 & 30.03 \\
\hline UTHLITIES & Unil & Univion Feed & gunit & s/ton Feed & ten: & 0005 & Santtery \\
\hline Process Water & $\mathrm{m} 3$ & 0.69 & 4.00 & 2.76 & 21 & 83 & 0.90 \\
\hline$\overline{\text { Total }}$ & & & & 44.16 & & 1,325 & 14.35 \\
\hline Wastewater & $\mathrm{m3}$ & 0.85 & 6.25 & 5.31 & 25,500 & 159 & 1.73 \\
\hline Hazardous Waste & $\mathrm{kg}$ & 29.20 & 0.40 & 11.68 & 876 & 350 & 3.80 \\
\hline Operating Supplies & TI. & $10.0 \%$ & 3,521 & 11.74 & & 352 & 3.31 \\
\hline Transportation (Batteries) & ton & 1.00 & 50.00 & 50.00 & 30,000 & 1,500 & 16.25 \\
\hline
\end{tabular}

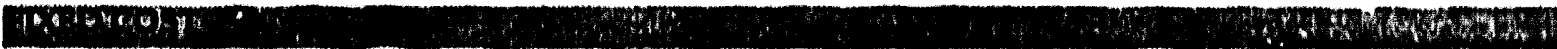

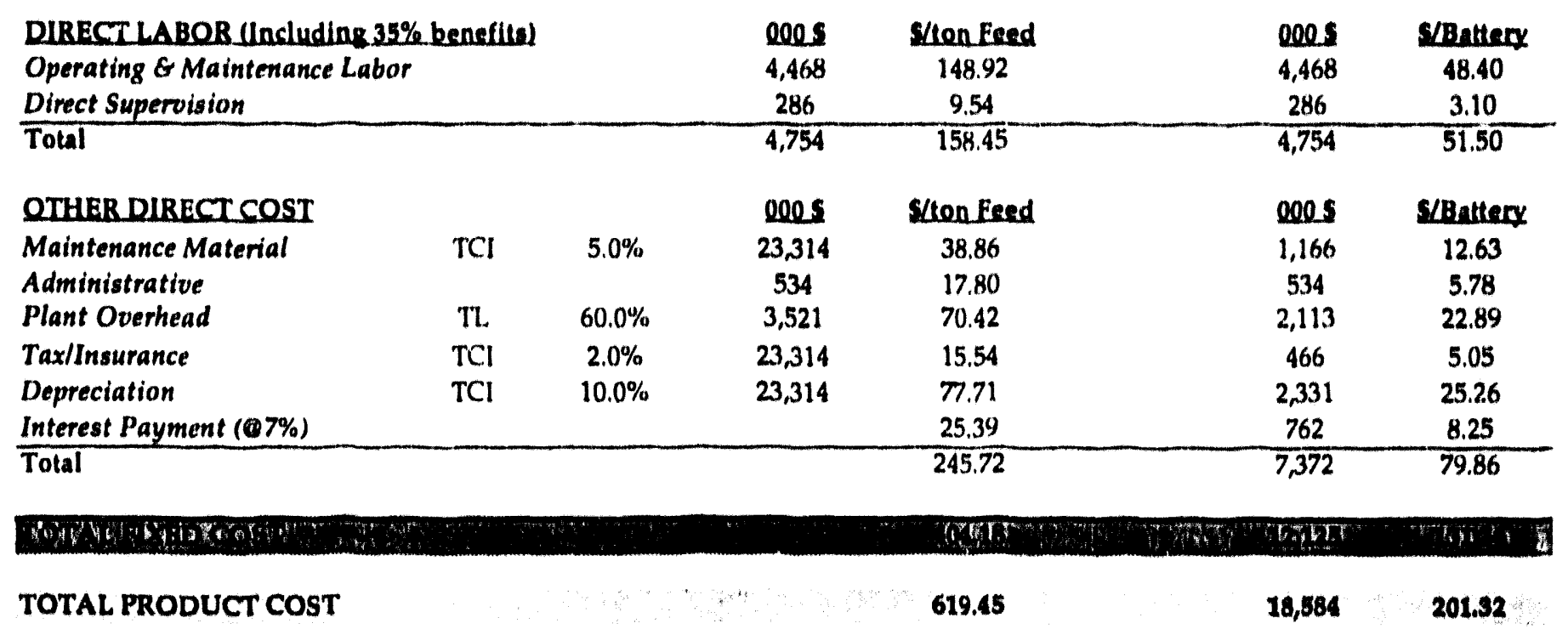


Table 5-6. AB2 Alloy Physical Separation/Chemical Process Operating Cost Estimate

Production (Feed) $\quad 30,000 \quad$ tons/year

\section{BY-PRODUCT CREDITS}

\begin{tabular}{|c|c|c|c|c|c|c|c|c|}
\hline PRODUCTS & $\%$ Primary & Unit & Unit/ton Feed & \$/Unit & S/ton Feed & tons & $000 \$$ & \$/Battery \\
\hline Nickel & & $\mathrm{kg}$ & 66.70 & 4.40 & 293.48 & 2,001 & 8,804 & 95.38 \\
\hline Ni/Fe Scrap & $55.6 \%$ & $\mathrm{~kg}$ & 264.60 & 2.45 & 648.27 & 7,938 & 19,448 & 210.69 \\
\hline Steel Scrap & & kg & 294.00 & 0.10 & 29.40 & 8,820 & 882 & 9.56 \\
\hline Polypropylene & & $\mathrm{kg}$ & 50.00 & 0.26 & 13.23 & 1,500 & 397 & 4.30 \\
\hline Hydride Alloy Scrap & & kg & 131.00 & 8.51 & 1114.28 & $3 ; 930$ & 33,428 & 362.14 \\
\hline $\mathrm{Ni}$ & $0.4 \%$ & $\mathrm{~kg}$ & 0.50 & 2.21 & 1.10 & 15 & 33 & 0.36 \\
\hline $\mathrm{Fe}$ & $1.1 \%$ & $\mathrm{~kg}$ & 1.40 & 0.00 & 0.00 & 42 & 0 & 0.00 \\
\hline$V$ & $54.3 \%$ & $k g$ & 71.10 & 8.82 & 627.10 & 2,133 & 18,813 & 203.81 \\
\hline $\mathrm{Zr}$ & $19.1 \%$ & $k g$ & 25.00 & 17.64 & 441.00 & 750 & 13,230 & 143.33 \\
\hline$T i$ & $6.0 \%$ & kg & 7.90 & 4.41 & 34.84 & 237 & 1,045 & 11.32 \\
\hline $\mathrm{Cr}$ & $16.3 \%$ & $k g$ & 21.40 & 0.36 & 7.79 & 642 & 234 & 2.53 \\
\hline$A l$ & $2.8 \%$ & $\mathrm{~kg}$ & 3.70 & 0.66 & 2.45 & 111 & 73 & 0.80 \\
\hline 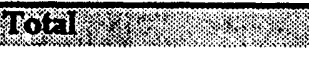 & ?. & 2 & 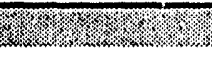 & V.r.? & 209866 & rat & 62960 & 682.06 \\
\hline
\end{tabular}


Table 5-6. AB2 Alloy Physical Separation/Chemical Process Operating Cost Estimate

\begin{tabular}{|c|c|c|c|c|c|}
\hline Labor Category & $\begin{array}{c}\text { \# of } \\
\text { Shifts }\end{array}$ & $\begin{array}{l}\text { Persons } \\
\text { Per Shift } \\
\end{array}$ & $\begin{array}{c}\text { Total } \\
\text { Persons }\end{array}$ & $\begin{array}{l}\text { Salary } \\
\$ / \text { Year } \\
\end{array}$ & Total \$/Year \\
\hline \multicolumn{6}{|l|}{ Operators } \\
\hline Process & 4.0 & 18 & 72.0 & 32,760 & $2,358,720$ \\
\hline Maintenance & 4.0 & 5 & 20.0 & 32,760 & 655,200 \\
\hline Foreman & 4.0 & 2 & 8.0 & $\frac{36,920}{\text { Subtotal }}$ & $\begin{array}{r}295,360 \\
3,309,280\end{array}$ \\
\hline \multicolumn{6}{|l|}{ Supervisors } \\
\hline Production Supervisor & 1.0 & 1.0 & 1.0 & 44,402 & 44,402 \\
\hline Utilities Engineers & 1.0 & 1.0 & 1.0 & 39,382 & 39,382 \\
\hline Facilities Engineers & 1.0 & 2.0 & 2.0 & 42,998 & 85,996 \\
\hline \multirow[t]{2}{*}{ Maintenance Supervisor } & 1.0 & 1.0 & 1.0 & 42,120 & 42,120 \\
\hline & & & & Subtotal & 211,900 \\
\hline \multicolumn{6}{|l|}{ Administrative } \\
\hline Plant Manager & 1.0 & 1.0 & 1.0 & 87,750 & 87,750 \\
\hline Chemist & 1.0 & 2.0 & 2.0 & 51,055 & 102,109 \\
\hline Controller & 1.0 & 1.0 & 1.0 & 44,460 & 44,460 \\
\hline Clerk & 1.0 & 1.0 & 1.0 & $24,570^{-}$ & 24,570 \\
\hline Secretary & 1.0 & 1.0 & 1.0 & 21,060 & 21,060 \\
\hline Nurse & 1.0 & 1.0 & 1.0 & 30,420 & 30,420 \\
\hline \multirow[t]{2}{*}{ Security } & 4.0 & 1.0 & 4.0 & 21,294 & 85,176 \\
\hline & & & & Subtotal & 395,545 \\
\hline \multicolumn{2}{|l|}{ Total Labor } & & 116.0 & & $3,916,725$ \\
\hline \multicolumn{5}{|c|}{ Total Employees/Labor Cost (with $35 \%$ benefits) } & $5,287,579$ \\
\hline
\end{tabular}

Sensitivity Analysis:

\begin{tabular}{|c|c|c|c|c|c|c|}
\hline Scenario & Unit & Base & High & Cost & Price Low & Process Cost \\
\hline By-Product & \$/Battery & 480.74 & & 2020.03 & & 470.79 \\
\hline Nickel & $\$ / 1 \mathrm{~b} \mathrm{Ni}$ & 2.00 & 8.43 & & 1.95 & \\
\hline $\mathrm{Ni} / \mathrm{Fe}$ Scrap & $\$ / \mathrm{lb} \mathrm{Ni}$ & 2.00 & 8.43 & & 1.95 & \\
\hline Steel Scrap & \$/gross ton & 100.00 & 128.00 & & 73.72 & \\
\hline $\begin{array}{l}\text { Hydride Alloy Scrap } \\
\text { Hydride Alloy Scrap }\end{array}$ & $\begin{array}{l}\$ / 1 \mathrm{bNl} \\
\$ / \mathrm{lbV}\end{array}$ & $\begin{array}{l}1.00 \\
4.00\end{array}$ & $\begin{array}{c}4.22 \\
14.80\end{array}$ & & $\begin{array}{l}0.98 \\
4.00\end{array}$ & \\
\hline Capital Investment & $\$ \mathrm{~mm}$ & 23.31 & 26.81 & 473.06 & 19.82 & 488.42 \\
\hline Interest Payrnent & $\%$ & $7.0 \%$ & $12.0 \%$ & 474.85 & $7.0 \%$ & 480.74 \\
\hline Electricity & $\$ /$ Kwh & 0.09 & 0.12 & 476.26 & 0.05 & 486.72 \\
\hline
\end{tabular}


Table 5-7. $A B_{5}$ alloy chemical process capital cost estimate

\begin{tabular}{|c|c|c|c|c|c|c|}
\hline Process Equipment & Number & $\begin{array}{c}\text { Purchase } \\
\text { Cost }\end{array}$ & $\begin{array}{c}\text { Total Process } \\
\text { Equipment } \\
\text { Cost }\end{array}$ & $\begin{array}{c}\text { Installation } \\
\text { Factor }\end{array}$ & $\begin{array}{c}\text { Tolal } \\
\text { Installed } \\
\text { Cost } \\
\end{array}$ & Description \\
\hline Cell Drainer & 1 & $\$ 20,000$ & $\$ 20,000$ & 2.5 & $\$ 50,000$ & custom \\
\hline Cell Case Remover & 1 & $\$ 20,000$ & $\$ 20,000$ & 2.5 & $\$ 50,000$ & custom \\
\hline Knile Mill & 1 & $\$ 47,000$ & $\$ 47,000$ & 2.5 & $\$ 117,500$ & granulator \\
\hline Shredder & 1 & $\$ 25,000$ & $\$ 25,000$ & 2.5 & $\$ 62,500$ & 2.5 ton per hour \\
\hline Screen & 1 & $\$ 6,269$ & $\$ 6,269$ & 2.32 & $\$ 14,544$ & vibrating, 2.5 TPH \\
\hline Magnetic Separator & 1 & $\$ 25,200$ & $\$ 25,200$ & 2.5 & $\$ 63,001$ & drum type, 2 TPH \\
\hline Leacher & 2 & $\$ 448,690$ & $\$ 897,379$ & 4.34 & $\$ 3,894,625$ & autoclave, $2,300 \mathrm{gal}$ \\
\hline Mixer Tantalum & 2 & $\$ 35,696$ & $\$ 71,392$ & 1.5 & $\$ 107,088$ & tantalum clad alloy steel \\
\hline Acid Siorage Tank & 2 & $\$ 89,532$ & $\$ 179,063$ & 3.29 & $\$ 589,118$ & $20 \%$ acid 25,000 gal \\
\hline Mixer-Settlers & 4 & $\$ 28,574$ & $\$ 114,297$ & 3.29 & $\$ 376,037$ & glass-lined steel, 2,300 gal \\
\hline Precipitator & 2 & $\$ 43,972$ & $\$ 87,943$ & 3.29 & $\$ 289,333$ & rubber-lined steel, $5,000 \mathrm{gal}$ \\
\hline Rolary Filler & 1 & $\$ 67,081$ & $\$ 67,081$ & 2.6 & $\$ 174,410$ & 350 cutt \\
\hline Tankhouse & 1 & $\$ 3,177,323$ & $\$ 3,177,323$ & 1 & $\$ 3,177,323$ & tankhouse, 42 cells \\
\hline Waste Neutralizers & 2 & $\$ 43,972$ & $\$ 87,943$ & 3.29 & $\$ 289,333$ & rubber-lined steel, $5,000 \mathrm{gal}$ \\
\hline Thickener & 1 & $\$ 180,234$ & $\$ 180,234$ & 3.29 & $\$ 592,970$ & rubber-lined concrete, $210 \mathrm{sq} 11$ \\
\hline Evaporation Pond & 1 & $\$ 3,500,000$ & $\$ 3,500,000$ & 1 & $\$ 3,500,000$ & 15 acres hypolined \\
\hline Hydrogen Flare & 1 & $\$ 50,000$ & $\$ 50,000$ & 3 & $\$ 150,000$ & gas assisted \\
\hline Conveyors & 10 & $\$ 10,030$ & $\$ 100,300$ & 2.69 & $\$ 269,807$ & various belt \& screw \\
\hline Pumps & 8 & $\$ 56,419$ & $\$ 451,350$ & 3.48 & $\$ 1,570,698$ & various \\
\hline Pumps & 10 & $\$ 4,500$ & $\$ 45,000$ & 3.48 & $\$ 156,600$ & various \\
\hline Cranes & 2 & $\$ 139,501$ & $\$ 279,002$ & 1.6 & $\$ 446,403$ & 20 T overhead \\
\hline Feoders & 6 & $\$ 11,346$ & $\$ 68,079$ & 2.3 & $\$ 156,581$ & vibratory \\
\hline Heat Exchangers & 2 & $\$ 46,000$ & $\$ 92,000$ & 2.7 & $\$ 248,400$ & tantalum \\
\hline Heat Exchangers & 6 & $\$ 12,000$ & $\$ 72,000$ & 3.39 & $\$ 244,080$ & steel \\
\hline Acid Storage Tank & 1 & $\$ 20,238$ & $\$ 20,238$ & 3.29 & $\$ 66,583$ & $80,000 \mathrm{gal}$ \\
\hline Caustic Storage Tank & 1 & $\$ 12,007$ & $\$ 12,007$ & 3.29 & $\$ 39,504$ & $80,000 \mathrm{gal}$ \\
\hline \multicolumn{3}{|c|}{ Total Process Equipment (Battery Limit) } & $\$ 9,696,100$ & & $\$ 16,696,435$ & \\
\hline
\end{tabular}

\begin{tabular}{|l|r|c|}
\hline Cost ttem & \multicolumn{1}{|c|}{$\begin{array}{c}\text { Total Cost } \\
1993 \$\end{array}$} & Basis \\
\hline Process Equipment & $\$ 16,696,435$ & \\
Oltsites & $\$ 5,008,931$ & $@ 30 \%$ PE \\
Utilities & $\$ 2,504,465$ & $@ 15 \%$ PE \\
\hline Total Plant Equipment & $\$ 21,705,366$ & \\
\hline Sile Preparalion & $\$ 667,857$ & $@ 4 \%$ PE \\
Land Acquisition & $\$ 1,000,000$ & $@ \$ 20,000 /$ acre \\
Buildings & $\$ 2,000,000$ & 50,000 sq t \\
Permits & $\$ 1,000,000$ & \\
Engineering & $\$ 2,420,983$ & $@ 10 \%$ TPE \\
Startup Cost & $\$ 2,420,983$ & $@ 10 \%$ TPE \\
\hline Indirect Costs & $\$ 9,509,824$ & \\
\hline Contingency & $\$ 4,682,278$ & $@ 15 \%$ TPE+ $+1 C$ \\
\hline Total Installed Cost & $\$ 35,897,468$ & \\
\hline
\end{tabular}


Table 5-8. AB5 Alloy Chemical Process Operating Cost Estimate

Production (Feed) $\quad 30,000 \quad$ tons/year

\begin{tabular}{|c|c|c|c|c|c|c|c|}
\hline & & $\begin{array}{c}\text { Consumption/ } \\
\text { ton Feed }\end{array}$ & Cost/Unit & $\begin{array}{c}\text { Cost/ton } \\
\text { Feed }\end{array}$ & Unit/Year & Cost & $\begin{array}{l}\text { Cost/EV } \\
\text { Battery }\end{array}$ \\
\hline prupr 5 oppose & & & & $2 x$ & & & \\
\hline $\begin{array}{l}\text { RAWMATERIALS } \\
\text { Batteries }\end{array}$ & $\frac{\text { Unit }}{\mathrm{kg}}$ & $\frac{\text { Unit/ton Feed }}{1000.00}$ & s/Unit & Slton Feed & $\begin{array}{c}\text { tons } \\
30,000\end{array}$ & $000 \mathrm{~s}$ & S/Battery \\
\hline HCl (35\% aqueous) & $\mathrm{kg}$ & 1043.43 & 0.06 & 63.27 & 31,303 & 1,898 & 20.56 \\
\hline $\mathrm{NaCH}$ ( $50 \%$ aqueous) & $\mathrm{kg}$ & 405.60 & 0.33 & 134.15 & 12,168 & 4,025 & 43.60 \\
\hline $\mathrm{NaOCl}$ (9\% aqueous) & $\mathrm{kg}$ & 362.22 & 0.46 & 0.17 & 10,867 & 5 & 0.05 \\
\hline
\end{tabular}

\begin{tabular}{|c|c|c|c|c|c|c|c|}
\hline Total & & & & 197.59 & & 5,928 & 64.22 \\
\hline UTILITIES & Unit & Unit/ton Feed & s/Unit & S/ton Feed & tons & $\underline{000 s}$ & \$/Battery \\
\hline Electricity & Kwh & 650.00 & 0.09 & 58.50 & 19,500 & 1,755 & 19.01 \\
\hline Process Water & $\mathrm{m} 3$ & 2.16 & 4.00 & 8.64 & 65 & 259 & 2.81 \\
\hline Total & & & & 67.14 & & 2,014 & 21.82 \\
\hline OTHER & Unit & Unit/ton Feed & \$/Unit & s/ton Feed & tons & $000 s$ & \$/Battery \\
\hline$\overline{\text { Wastewater }}$ & $\mathrm{m3}$ & 2.24 & 6.25 & 14.00 & 67,200 & 420 & 4.55 \\
\hline Solid Waste & $\mathrm{kg}$ & 201.400 & 0.00 & 0.00 & 6,042 & 0 & 0.00 \\
\hline Operating Supplies & TL & $10.0 \%$ & 3,259 & 10.86 & & 326 & 3.53 \\
\hline Transportation (Batteries) & ton Feed & 1.000 & 50.00 & 50.00 & 30,000 & 1,500 & 16.25 \\
\hline
\end{tabular}

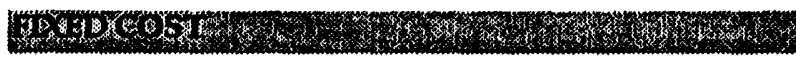

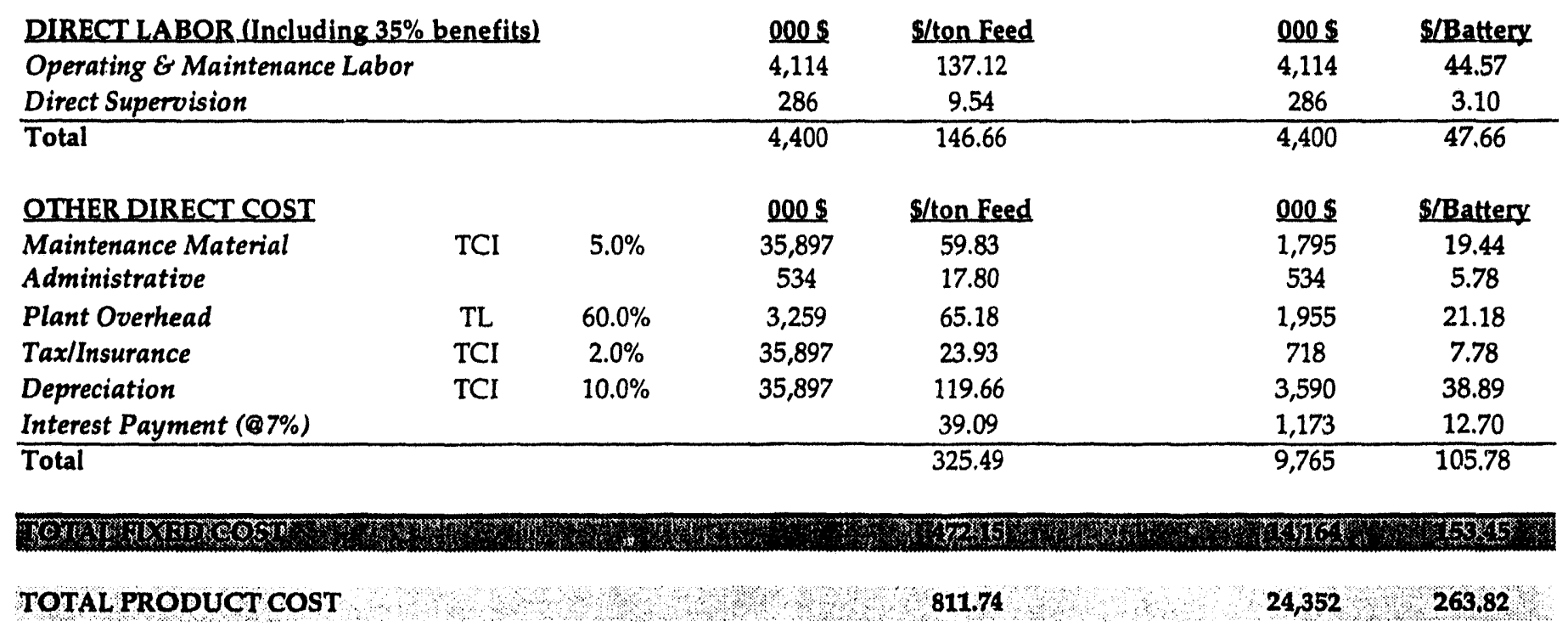


Table 5-8. AB5 Alloy Chemical Process Operating Cost Estimato

Production (Feed) $\quad 30,000 \quad$ tons/year

BY-PRODUCT CREDITS

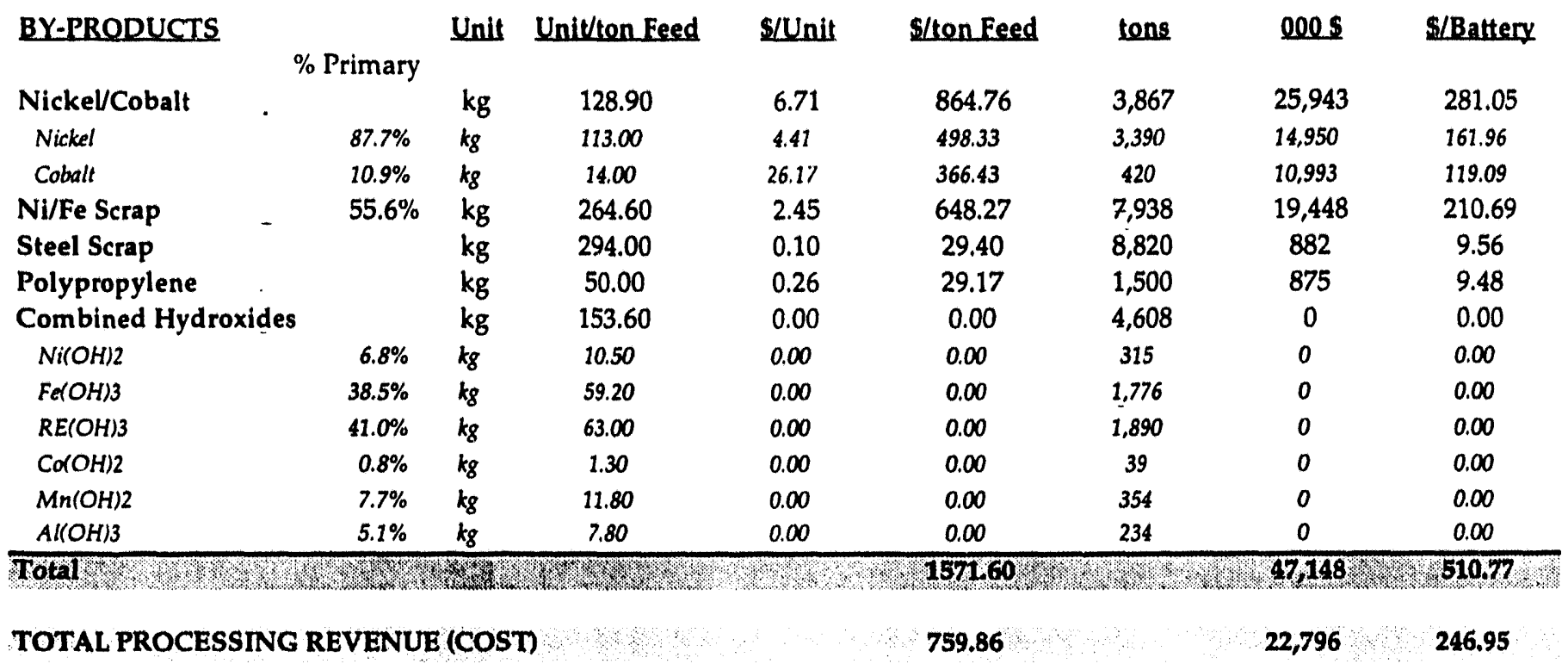


Table 548: AB5 Alloy Chemical Process Operating Cost Estimate

\begin{tabular}{|c|c|c|c|c|c|}
\hline Labor Category & $\begin{array}{c}\# \text { of } \\
\text { Shifts }\end{array}$ & $\begin{array}{l}\text { Persons } \\
\text { Per Shift }\end{array}$ & $\begin{array}{c}\text { Total } \\
\text { Persons }\end{array}$ & $\begin{array}{l}\text { Salary } \\
\$ / \text { Year }\end{array}$ & Total \$/Year \\
\hline \multicolumn{6}{|l|}{ Qperatore } \\
\hline Process & 4.0 & 16 & 64.0 & 32,760 & $2,096,640$ \\
\hline Maintenance & 4.0 & 5 & 20.0 & 32,760 & 655,200 \\
\hline \multirow[t]{2}{*}{ Eoreman } & 4.0 & 2 & 8.0 & 36,920 & 295,360 \\
\hline & & & & Subtotal & $3,047,200$ \\
\hline \multicolumn{6}{|l|}{ Supervisers } \\
\hline Production Supervisor & 1.0 & 1.0 & 1.0 & 44,402 & 44,402 \\
\hline IItillties Engineers & 1.0 & 1.0 & 1.0 & 39,382 & 39,382 \\
\hline Facilities Engineers & 1.0 & 2.0 & 2.0 & 42,998 & 85,996 \\
\hline \multirow[t]{2}{*}{ Maintenance Supervisor } & 1.0 & 1.0 & 1.0 & 42,120 & 42,120 \\
\hline & & & & Subtotal & 211,900 \\
\hline \multicolumn{6}{|l|}{ Administrative } \\
\hline Plant Manager & 1.0 & 1.0 & 1.0 & 87,750 & 87,750 \\
\hline Chemist & 1.0 & 2.0 & 2.0 & 51,055 & 102,109 \\
\hline Controller & 1.0 & 1.0 & 1.0 & 44,460 & 44,460 \\
\hline Clerk & 1.0 & 1.0 & 1.0 & 24,570 & 24,570 \\
\hline Secretary & 1.0 & 1.0 & 1.0 & 21,060 & 21,060 \\
\hline Nurse & 1.0 & 1.0 & 1.0 & 30,420 & 30,420 \\
\hline \multirow[t]{2}{*}{ Security } & 4.0 & 1.0 & 4.0 & 21,294 & 85,176 \\
\hline & & & & Subtotal & 395,545 \\
\hline Total Labor & & & 108.0 & & $3,654,645$ \\
\hline \multicolumn{5}{|c|}{ Total Employees/Labor Cost (with $35 \%$ benefito) } & $4,933,771$ \\
\hline
\end{tabular}

Sensitivity Analysis:

\begin{tabular}{|l|c|ccccc|}
\hline \multicolumn{1}{|c|}{ Scenario } & Unit & Base & High & Cost & Price Low & Process Cost \\
\hline By-Product & s/Battery & 246.95 & & 1459.02 & & 199.11 \\
Nickel/Cobalt (Ni) & S/lb Ni & 2.00 & 8.43 & & 1.95 & \\
Nickel/Cobalt (Co) & s/lb Co & 11.87 & 13.00 & & 8.28 & \\
Ni/Fe Scrap & \$/lb Ni & 2.00 & 8.43 & & 1.95 & \\
Steel Scrap & S/gross ton & 100.00 & 128.00 & & 73.72 & \\
\hline Capital Investment & \$mm & 35.90 & 41.28 & 235.13 & 30.51 & 258.78 \\
Interest Payment & $\%$ & $7.0 \%$ & $12.0 \%$ & 237.88 & $7.0 \%$ & 246.95 \\
Electricity & \$/Kwh & 0.09 & 0.12 & 240.62 & 0.05 & 255.40 \\
\hline
\end{tabular}


The capital investment for the pyrometallurgical process at the $\mathrm{AB}_{5}$ processing plant, including materials preparation, smelting, refining, waste neutralization, and disposal, was $\$ 34.8$ million for the 30,000-metric-tons-per-year plarit. The details of the capital cost estimate are shown in Table 5-9. The operating revenue of the plant was $\$ 108.27$ per EV batter, or $\$ 1.35 / \mathrm{kWh}$ of EV. The details of the operating revenue are shown in Table 5-10.

The capital investment for the physical separation and chemical process at the $A B_{s}$ processing plant, including materials preparation, leaching, electrowinning, waste neutralization, and disposal, was $\$ 23.3$ million for the 30,000-metric-tons-per-year plant. The details of the capital cost estimate are shown in Table 5-11. The operating revenue-of the plant was $\$ 434.34$ per EV battery, or $\$ 5.43 / \mathrm{kWh}$ of EV. The details of the operating revenue are shown in Table 5-12.

\subsection{Cost Sensitivities}

The sensitivity of the operating revenue was estimated for several cases:

- for a variation in the electricity cost between $\$ 0.05$ and $\$ 0.12$ per $\mathrm{kWh}$;

- for a variation in the by-product credits for the nickel, vanadium, and steel for the highest and lowest market price over the past five years;

- for a variation in the interest rate from the current low of 7 percent to a high of 12 percent; and

- for a 15 percent variation in the capital investment.

The sensitivities are summarized and shown in Table 5-1 to 5-8 for the $\mathrm{AB}_{2}$ and $A \mathrm{~B}_{5}$ cells.

In the case of the $\mathrm{AB}_{2}$ alloy, the physical separation/chemical process generates the greatest revenue. The chemical process will operate at a small cost. The most significant sensitivity is the value of the by-product credits. The pyrometallurgical process is most sensitive to the cost of electricity. The capital investment and interest rate sensitivities have minor impact on the operating revenue. 
Table 5-9. $A B_{B}$ alloy pyrometallurgical process capital cost estimate

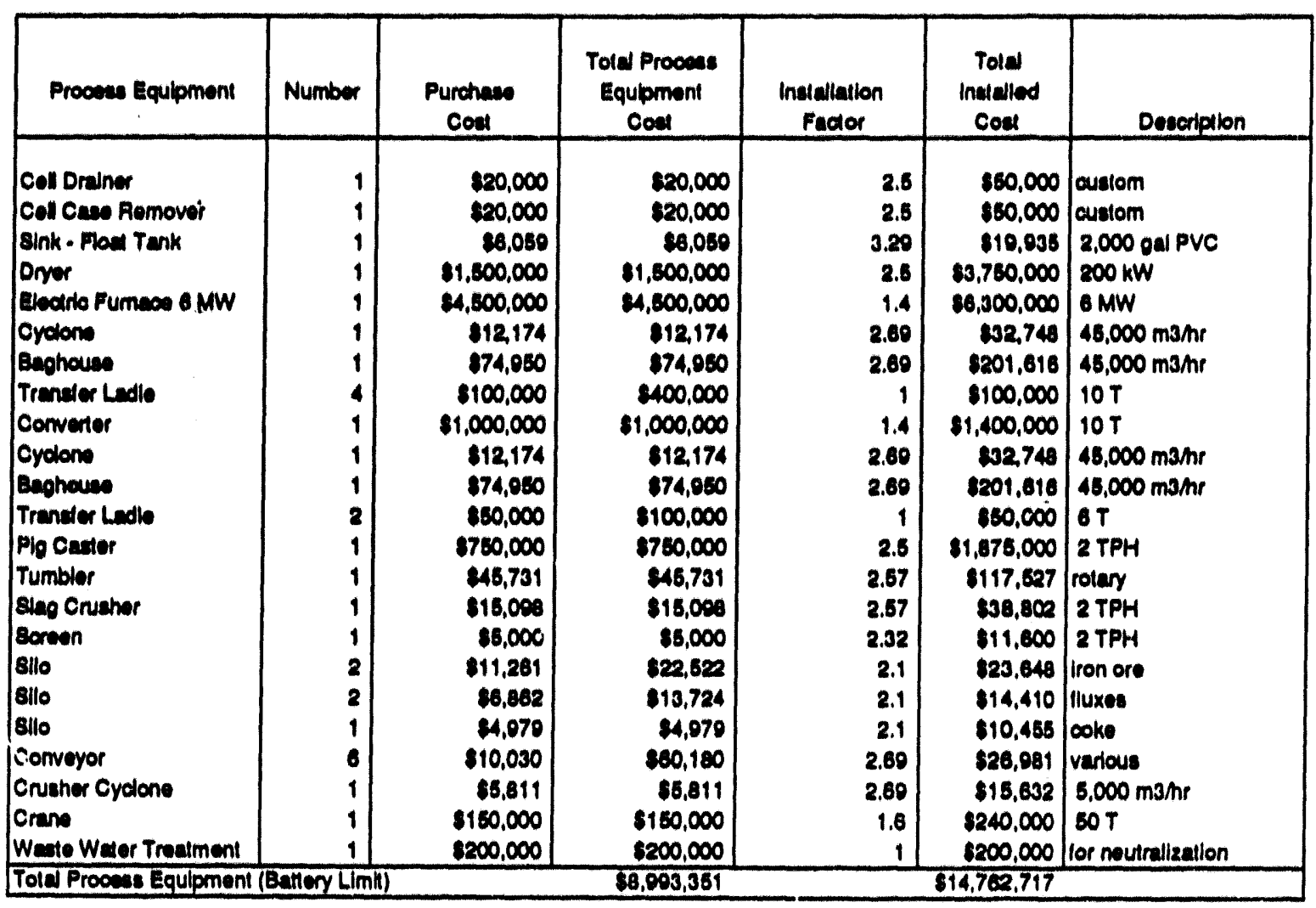

\begin{tabular}{|c|c|c|}
\hline Cout llem & $\begin{array}{c}\text { Total Cost } \\
10238\end{array}$ & Basis \\
\hline Procses Equipment & $\$ 14.762 .717$ & \\
\hline Ottaties & $\$ 4,428,816$ & (10\% PE \\
\hline Utiliaies & $\$ 2,214,408$ & Q15\% PE \\
\hline Total Plant Equbment & $\$ 21,405,940$ & \\
\hline Sho Preparallon & $\$ 600,500$ & (194\% PE \\
\hline Land Acquialtion & $\$ 1,000,000$ & (1) 520,000 / acre \\
\hline Bulldings & $\$ 2,000,000$ & 60,000 eq $\mathrm{H}$ \\
\hline Pormits & $\$ 1,000,000$ & \\
\hline Engineering & $\$ 2,140,504$ & (10\% TPE \\
\hline Statup Coot & $\$ 2,140,504$ & Q10\% TPE \\
\hline Indireal Costs & $88,871,697$ & \\
\hline Contingengy & $\$ 4,541,646$ & (915\% TPE + IC \\
\hline Total Installed Cost & $\$ 34,810,282$ & \\
\hline
\end{tabular}


Table 5-10 AEs Alloy Pyrometallurgloal Proceses Operating Cost Eatimate

Production (Feed) $\quad 30,000 \quad$ tons/year

\begin{tabular}{|c|c|c|c|c|c|c|c|}
\hline & & $\begin{array}{c}\text { Consumption } \\
\text { ton Feed }\end{array}$ & Costunit & $\begin{array}{l}\text { Costion } \\
\text { Feed } \\
\end{array}$ & Unitrear & Cost & $\begin{array}{l}\text { CostEV } \\
\text { Battery } \\
\end{array}$ \\
\hline \multicolumn{8}{|c|}{ VARIABLE OPBRATINO COST } \\
\hline RAWMATERIALS & Unil & Unit/on Feed & sunis & Shon Fend & lon & 0005 & sintex \\
\hline Batteries & $\mathrm{kg}_{\mathbf{8}}$ & 1000.00 & 0.00 & 0.00 & 30,000 & 0 & 0.00 \\
\hline Lime & $\mathbf{k g}$ & 37.57 & 0.04 & 1.66 & 1,127 & 50 & 0.54 \\
\hline Silica & kg & 18.76 & 0.03 & 0.52 & 563 & 16 & 0.17 \\
\hline Iron Ore & kg & 62.49 & 0.03 & 2.03 & 1,875 & 61 & 0.66 \\
\hline Coke Breeze & $\mathbf{k g}_{\mathbf{g}}$ & 40.44 & 0.06 & 2.43 & 1,213 & 73 & 0.79 \\
\hline Fest $(75 \%$ St) & kg & 6.25 & 0.99 & 6.20 & 187 & 186 & 2.01 \\
\hline Oxygen & $\mathrm{m} 3$ & 26.81 & 0.20 & 5.31 & 804 & 159 & 1.73 \\
\hline Electrodes & $k_{8}$ & 15.00 & 2.00 & 30.00 & 450 & 900 & 9.75 \\
\hline Total & & & & 48.14 & & 1,444 & 15.65 \\
\hline ITILTOEs & Unit & Unitlen Fied & s/Unit & Ston Reed & 000 Unit & 0.005 & S/Bnttery \\
\hline Natural Gas & $\mathrm{m} 3$ & 3.91 & 0.09 & 0.35 & 117 & 11 & 0.11 \\
\hline Electricity & Kwh & 1,100 & 0.09 & 99.00 & 33,000 & 2,970 & 32.18 \\
\hline Process Water & $\mathrm{m} 3$ & 0.06 & 4.00 & 0.24 & 2 & 7 & 0.08 \\
\hline Total & & & & 99.59 & & 2,988 & 32.37 \\
\hline OTHER & Unit & Unititon Feed & s/Unit & Stonfind & ton: & $000 \mathrm{~s}$ & S/Buttery \\
\hline Wastewater & $\mathrm{m} 3$ & 0.16 & 6.25 & 1.00 & 4,800 & 30 & 0.33 \\
\hline $\begin{array}{l}\text { Hazardous Waste } \\
\text { Operating Supplies }\end{array}$ & $\mathrm{kg}$ & $\begin{array}{l}30.00 \\
10.0 \%\end{array}$ & $\begin{array}{l}0.40 \\
3,390\end{array}$ & $\begin{array}{l}12.00 \\
11.30\end{array}$ & 900 & $\begin{array}{l}360 \\
339\end{array}$ & $\begin{array}{l}3.90 \\
3.67\end{array}$ \\
\hline Transportation (Batteries) & ton Feed & 1.00 & 50.00 & 50.00 & 30,000 & 1,500 & 16.25 \\
\hline TOTALVARABLBCOST & 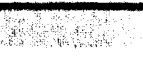 & & & 222.01 & & 6,651 & 72.16 \\
\hline
\end{tabular}

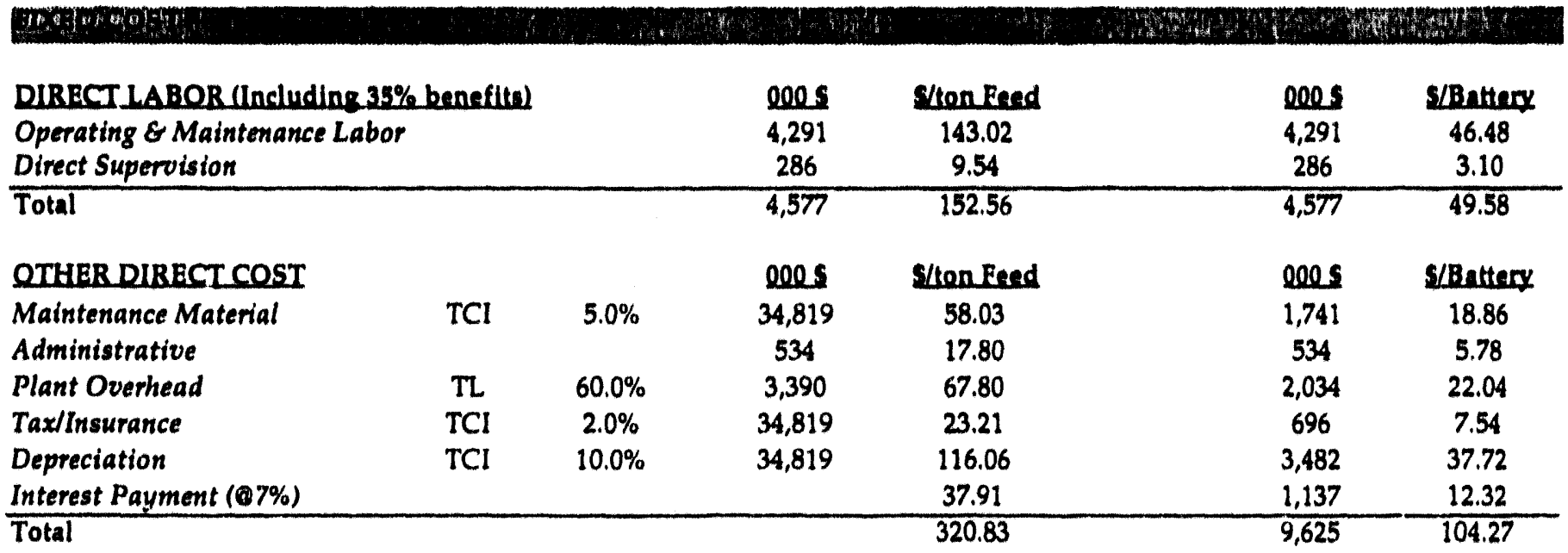

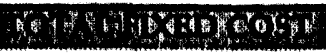

1,13

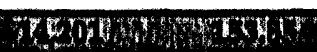


Table 8-10. ABs Alloy Pyrometallurglod Procese Operating Cost Estimate

Production (Feed) $\quad 30,000 \quad$ Ions/year

BY-PRODUCT CREDITS

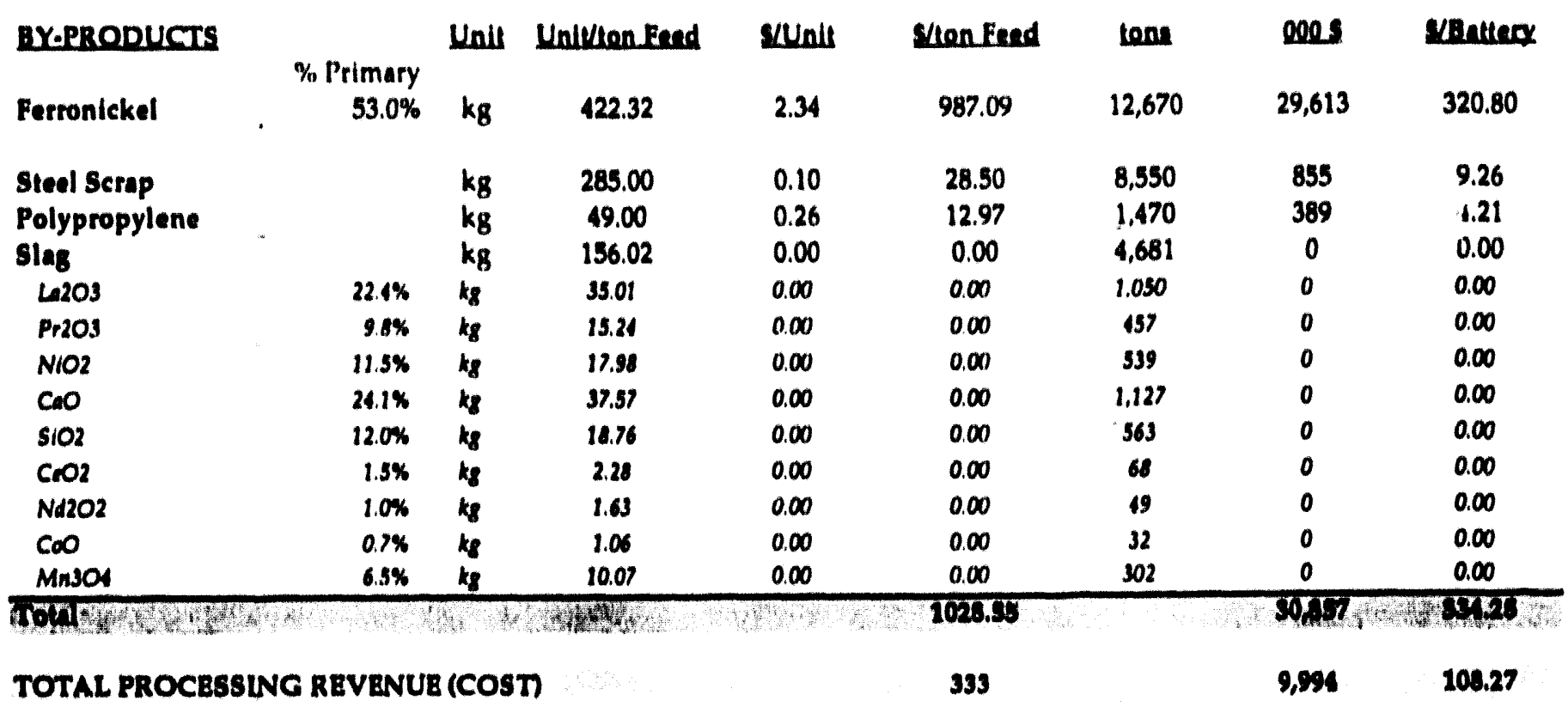




\begin{tabular}{|c|c|c|c|c|c|}
\hline Labor Category & $\begin{array}{l}\text { It of } \\
\text { Shifts }\end{array}$ & $\begin{array}{l}\text { Persons } \\
\text { Per Shift }\end{array}$ & $\begin{array}{l}\text { Total } \\
\text { Persons }\end{array}$ & $\begin{array}{l}\text { Salary } \\
\text { \$/Year }\end{array}$ & Total S/Year \\
\hline \multicolumn{6}{|l|}{ Onantor } \\
\hline Process & 4.0 & 18 & 72.0 & 32,760 & $2,358,720$ \\
\hline Maintenance & 4.0 & 4 & 16.0 & 32,760 & 524,160 \\
\hline Eqremen & 4.0 & 2 & 8.0 & $\frac{36,920}{\text { subtotal }}$ & $\begin{array}{r}295,360 \\
3,178,240\end{array}$ \\
\hline \multicolumn{6}{|l|}{ Suponiton } \\
\hline Production Supervisor & 1.0 & 1.0 & 1.0 & 44,402 & 44,402 \\
\hline Uttlites Engliners & 1.0 & 1.0 & 1.0 & 39,382 & 39,382 \\
\hline Padlltes Bngineers & 1.0 & 2.0 & 2.0 & 42,998 & 85,996 \\
\hline \multirow[t]{2}{*}{ Maintenance Supervitor } & 1.0 & 1.0 & 1.0 & 42,120 & 42,120 \\
\hline & & & & Subtotal & 211,900 \\
\hline \multicolumn{6}{|l|}{ Adminintentive } \\
\hline Plant Manager & 1.0 & 1.0 & 1.0 & 87,750 & 87,730 \\
\hline Chemilat & 1.0 & 2.0 & 2.0 & 51,055 & 102,109 \\
\hline Controller & 1.0 & 1.0 & 1.0 & 44,460 & 44,460 \\
\hline Clerk & 1.0 & 1.0 & 1.0 & 24,570 & 24,570 \\
\hline Secretary & 1.0 & 1.0 & 1.0 & 21,060 & 21,060 \\
\hline Nurse & 1.0 & 1.0 & 1.0 & 30,420 & 30,420 \\
\hline \multirow[t]{2}{*}{ Securtly } & 4.0 & 1.0 & 4.0 & 21,294 & 85,176 \\
\hline & & & & Subtotal & 393,545 \\
\hline Total Labor & & & $\mathbf{1 1 2 . 0}$ & & $3,785,655$ \\
\hline \multicolumn{5}{|c|}{ Total Employeou/Labor Coat (with $35 \%$ benafita) } & $3,110,675$ \\
\hline
\end{tabular}

Senaitivity Analyole:

\begin{tabular}{|c|c|c|c|c|c|c|}
\hline Scenario & Undt & Base & High & Coot & Price Low & Process Cost \\
\hline $\begin{array}{l}\text { By-Product } \\
\text { Perronickel } \\
\text { Steel Scrap }\end{array}$ & $\begin{array}{l}\text { PBattery } \\
\text { s/lb NI } \\
\text { s/gross ton }\end{array}$ & $\begin{array}{c}108.27 \\
2.00 \\
100.00\end{array}$ & $\begin{array}{c}8.43 \\
128.00\end{array}$ & 1162.25 & $\begin{array}{r}1.95 \\
73.72\end{array}$ & 00 \\
\hline $\begin{array}{l}\text { Capital Investment } \\
\text { Interest Payment } \\
\text { Blectricity }\end{array}$ & $\begin{array}{c}5 \mathrm{smm} \\
\% \\
s / \mathrm{Kwh}\end{array}$ & $\begin{array}{l}34.82 \\
7.0 \% \\
0.09\end{array}$ & $\begin{array}{c}90.04 \\
12.0 \% \\
0.12\end{array}$ & $\begin{array}{l}96.80 \\
99.47 \\
97.54\end{array}$ & $\begin{array}{l}29.60 \\
7.0 \% \\
0.05\end{array}$ & $\begin{array}{l}119.74 \\
108.27 \\
122.57\end{array}$ \\
\hline
\end{tabular}


Table 5-11. ABs alloy physical separationchemical process capital cost estimate

\begin{tabular}{|c|c|c|c|c|c|c|}
\hline Procoses Equlpment & Number & $\begin{array}{l}\text { Purchess } \\
\text { Con }\end{array}$ & $\begin{array}{l}\text { Told Process } \\
\text { Equpment } \\
\text { Coet }\end{array}$ & $\begin{array}{c}\text { Inelatiation } \\
\text { Fedior }\end{array}$ & $\begin{array}{c}\text { Totel } \\
\text { Inctalled } \\
\text { Cost }\end{array}$ & Deseripilon \\
\hline 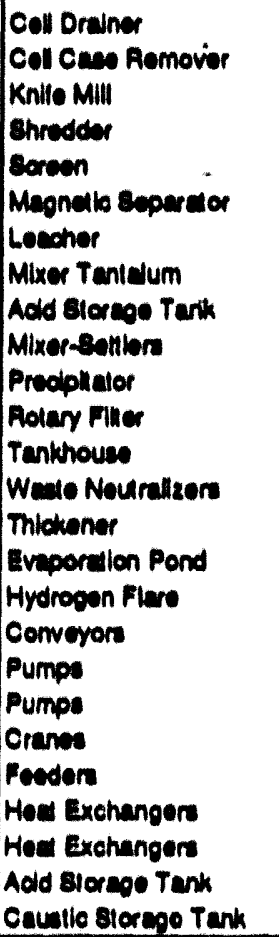 & $\begin{array}{r}1 \\
1 \\
1 \\
2 \\
2 \\
2 \\
2 \\
2 \\
1 \\
1 \\
1 \\
1 \\
2 \\
1 \\
1 \\
1 \\
10 \\
1 \\
10 \\
2 \\
6 \\
2 \\
6 \\
1 \\
1 \\
\end{array}$ & 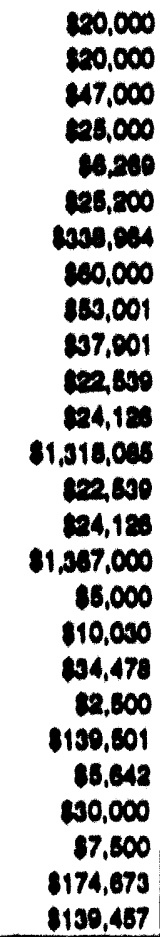 & 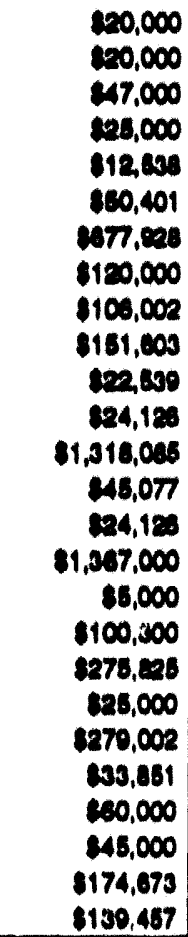 & $\begin{array}{r}2.8 \\
2.8 \\
2.5 \\
2.8 \\
2.02 \\
2.6 \\
4.34 \\
1.6 \\
3.20 \\
3.20 \\
3.20 \\
2.6 \\
1 \\
3.20 \\
3.20 \\
1 \\
3 \\
2.60 \\
3.40 \\
3.40 \\
1.6 \\
2.3 \\
2.7 \\
3.39 \\
3.20 \\
3.20\end{array}$ & 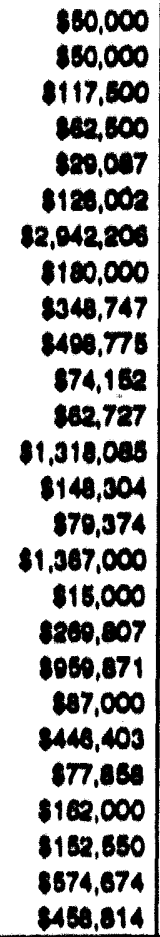 & 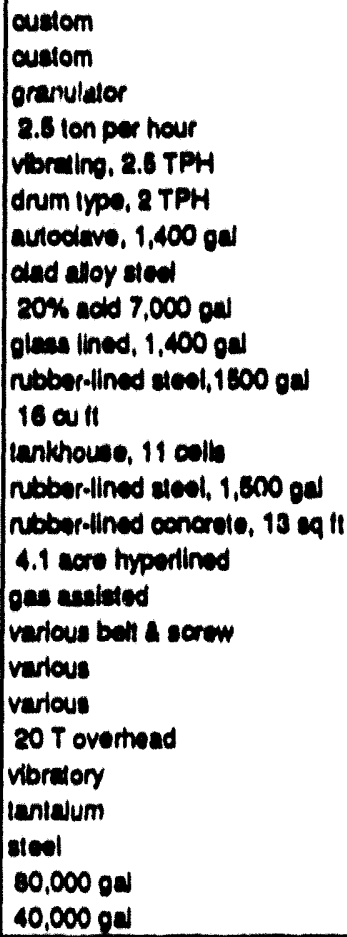 \\
\hline Told Procens Equipm & 7 & & $36,160,632$ & & $10,669,457$ & \\
\hline
\end{tabular}

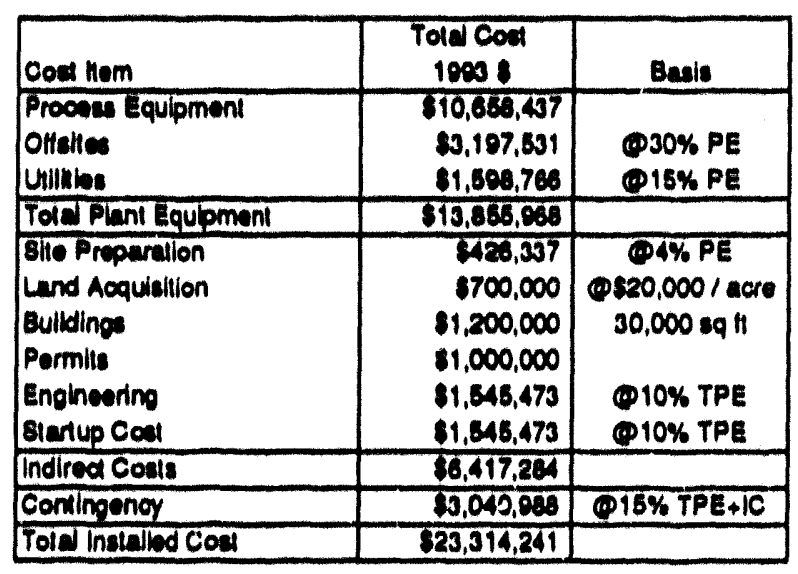


Table 5-12. ABB Alloy Phyaleal SeparatlonChemieal Proeses Operating Coat Eetimate

Production (Feed) $\quad 30,000 \quad$ tons/year

\begin{tabular}{|c|c|c|c|c|c|c|c|}
\hline & & $\begin{array}{c}\text { Consumption } \\
\text { Ion Feed }\end{array}$ & CosvUnit & $\begin{array}{l}\text { Costlion } \\
\text { Feed }\end{array}$ & Unitrear & Cost & $\begin{array}{l}\text { CosveV } \\
\text { Battery }\end{array}$ \\
\hline ARIABLB OPEYAT & & & & & & & mo \\
\hline RAWMATERIALS & Unit & Uniliton Fead & sunit & Mon Fend & tons & 0005 & SBatter \\
\hline $\begin{array}{l}\text { Batteries } \\
\text { HCl (35\% aqueous) }\end{array}$ & $\begin{array}{l}\mathrm{kg} \\
\mathrm{kg}\end{array}$ & $\begin{array}{c}1000.00 \\
355.43\end{array}$ & $\begin{array}{l}0.00 \\
0.06\end{array}$ & $\begin{array}{l}0.00 \\
21.55\end{array}$ & $\begin{array}{l}30,000 \\
10,663\end{array}$ & $\begin{array}{c}0 \\
647\end{array}$ & $\begin{array}{l}0.00 \\
7.00\end{array}$ \\
\hline NaOH (50\%aqueous) & kg & 217.40 & 0.33 & 71.91 & 6,522 & 2,157 & 23.37 \\
\hline
\end{tabular}

\begin{tabular}{|c|c|c|c|c|c|c|c|}
\hline Tolal & & & & 93.46 & & 2,804 & 30.37 \\
\hline JTUL.ITIRS & Unil & Univiton Feed & sulnit & Ston Fend & ten: & $000 \mathrm{~s}$ & SBitter \\
\hline Process Water & m3 & 0.71 & 4.00 & 2.84 & 21 & 85 & 0.92 \\
\hline Total & & & & 44.24 & & 1,327 & 14.38 \\
\hline Wastewater & $\mathrm{m3}$ & 0.86 & 6.25 & 5.38 & 25,800 & 161 & 1.75 \\
\hline $\begin{array}{l}\text { Hazardous Waste } \\
\text { Operating Supplics }\end{array}$ & $\frac{k_{8}}{T L}$ & $\begin{array}{r}29.20 \\
10.0 \%\end{array}$ & $\begin{array}{l}0.40 \\
3,521\end{array}$ & $\begin{array}{l}11.68 \\
11.74\end{array}$ & 876 & $\begin{array}{l}350 \\
352\end{array}$ & $\begin{array}{l}3.80 \\
3.81\end{array}$ \\
\hline Transportation (Batteries) & ton Feed & 1.00 & 50.00 & 50.00 & 30,000 & 1,500 & 16.25 \\
\hline
\end{tabular}

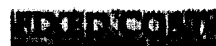

DIRECT LABOR Induding $35 \%$ benefle)
Operating \& Maintenance Labor
Direct Superolsion
Total

OTHER DIRECT COST

Maintenance Material

Administrative

Plant Overhead

Tax/Insurance

Depreciation

Interest Payment (07\%)

Total

\begin{tabular}{cccc} 
bensfital & & 000 s & Sten Feed \\
& & 4,468 & 148.92 \\
& & 286 & 9.54 \\
\hline & & 4,754 & 158.45 \\
& & 0005 & s/ton Feed \\
$\mathrm{TCl}$ & $5.0 \%$ & 23,314 & 38.86 \\
& & 534 & 17.80 \\
$\mathrm{TL}$ & $60.0 \%$ & 3,521 & 70.42 \\
$\mathrm{TCl}$ & $2.0 \%$ & 23,314 & 15.54 \\
$\mathrm{TCl}$ & $10.0 \%$ & 23,314 & 77.71 \\
& & & 25.39 \\
\hline
\end{tabular}

\begin{tabular}{cc} 
OOOS & S/Butter \\
\hline 4,468 & 48.40 \\
286 & 3.10 \\
\hline 4,754 & 51.50 \\
& \\
Does & S/Battery \\
1,166 & 12.63 \\
534 & 5.78 \\
2,113 & 22.89 \\
466 & 5.05 \\
2,331 & 25.26 \\
762 & 8.25 \\
\hline 7,372 & 79.86
\end{tabular}


Table 8-12. ABB Alloy Physioal separatlonchemioal Process Operating Cost Estimate

Production (Feed) $\quad 30,000 \quad$ tons/year

BY-PRODUCT CREDITS

BY.PRODUCTS

\% Primary

Nickel

NI/Fe Scrap

Steel Scrup

Polypropylene

Hydride Alloy Scrap

$\mathrm{Ni}$

Fe

RE

Co

$\mathrm{Mn}$

Al
Unil Unit/ton Feed

kg $\quad 66.70$

kg $\quad 264.60$

kg 294.00

$\mathrm{kg} \quad 50.00$

kg $\quad 78.90$

$0.6 \%$

$1.8 \%$

$62.9 \%$

$21.2 \%$

$9.9 \%$

$3.7 \%$
78.90
0.50

1.10

49.60

16.70

7.80

2.90 sunill stonfeed

4.40

2.45

0.10

0.26

12.33

2.21

0.00

11.03

24.81

1.10

0.66
Stonfeed tom

293.48

648.27

29.40

13.23

972.72

1.10

0.00

346.84

$\$ 11.26$

8.60

1.92
2,001

7,938

8,820

1,500

2,367

15

12

1,488

501

234

87 ooes vBntiery

8,804

19,448

882

397

29,182

33

0

16,405

12,128

258

$\boldsymbol{s}$

95.38

210.69

9.56

4.30

316.14

0.36

0.00

171.72

134.64

2.79

0.62

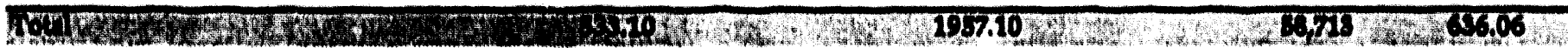


Table 5-12: AB5 Alloy Physical Separation/Chemical Process Operating Cost Estimate

\begin{tabular}{|c|c|c|c|c|c|}
\hline Labor Category & $\begin{array}{l}\text { \# of } \\
\text { Shifts }\end{array}$ & $\begin{array}{l}\text { Persons } \\
\text { Per Shift }\end{array}$ & $\begin{array}{c}\text { Total } \\
\text { Persons }\end{array}$ & $\begin{array}{l}\text { Salary } \\
\$ / \text { Year }\end{array}$ & Total \$/Year \\
\hline \multicolumn{6}{|l|}{ Qperators } \\
\hline Process & 4.0 & 18 & 72.0 & 32,760 & $2,358,720$ \\
\hline Maintenance & 4.0 & 5 & 20.0 & 32,760 & 655,200 \\
\hline Eoreman & 4.0 & 2 & 8.0 & $\frac{36,920}{\text { Subtotal }}$ & $\frac{295,360}{3,309,280}$ \\
\hline \multicolumn{6}{|l|}{ Supervisors } \\
\hline Production Supervisor & 1.0 & 1.0 & 1.0 & 44,402 & 44,402 \\
\hline Utilities Engineers & 1.0 & 1.0 & 1.0 & 39,382 & 39,382 \\
\hline Facilities Erigineers & 1.0 & 2.0 & 2.0 & $42,998^{-}$ & 85,996 \\
\hline \multirow[t]{2}{*}{ Maintenance Supervisor } & 1.0 & 1.0 & 1.0 & 42,120 & 42,120 \\
\hline & & & & Subtotal & 211,900 \\
\hline \multicolumn{6}{|l|}{ Administrative } \\
\hline Plant Manager & 1.0 & 1.0 & 1.0 & 87,750 & 87,750 \\
\hline Chemist & 1.0 & 2.0 & 2.0 & 51,055 & 102,109 \\
\hline Controller & 1.0 & 1.0 & 1.0 & 44,460 & 44,460 \\
\hline Clerk & 1.0 & 1.0 & 1.0 & 24,570 & 24,570 \\
\hline Secretary & 1.0 & 1.0 & 1.0 & 21,060 & 21,060 \\
\hline Nurse & 1.0 & 1.0 & 1.0 & 30,420 & 30,420 \\
\hline \multirow[t]{2}{*}{ Security } & 4.0 & 1.0 & 4.0 & 21,294 & 85,176 \\
\hline & & & & Subtotal & 395,545 \\
\hline Total Labor & & & 116.0 & & $3,916,725$ \\
\hline \multicolumn{5}{|c|}{ Total Employees/Labor Cost (with $35 \%$ benefits) } & $5,287,579$ \\
\hline
\end{tabular}

Sensitivity Analysis:

\begin{tabular}{|l|c|ccccc|}
\hline \multicolumn{1}{|c|}{ Scenario } & Unit & Base & High & Cost & Price Low & Process Cost \\
\hline By-Product & \$/Battery & $\mathbf{4 3 4 . 3 4}$ & & $\mathbf{1 4 3 6 . 1 7}$ & & $\mathbf{3 8 3 . 6 7}$ \\
Nickel & \$/lb Ni & 2.00 & $\delta .43$ & & 1.95 & \\
Ni/Fe Scrap & \$/lb Ni & 2.00 & 8.43 & & 1.95 & \\
Steel Scrap & \$/gross ton & 100.10 & 128.00 & & 73.72 & \\
Hydride Alloy Scrap & \$/lb Ni & 1.00 & 4.22 & & 0.98 & \\
Hydride Alloy Scrap & $\$ / \mathrm{lb} \mathrm{Co}$ & 11.25 & 12.32 & & 7.85 & \\
\hline Capital Investment & \$mm & 23.31 & 26.81 & 426.66 & 19.82 & 442.02 \\
Interest Payment & $\%$ & $7.0 \%$ & $12.0 \%$ & 428.45 & $7.0 \%$ & 434.34 \\
Electricity & $\$ /$ Kwh & 0.09 & 0.12 & 429.86 & 0.05 & 440.32 \\
\hline
\end{tabular}


Figure 5-1: Impact of by-product credits on AB2 process operating cost

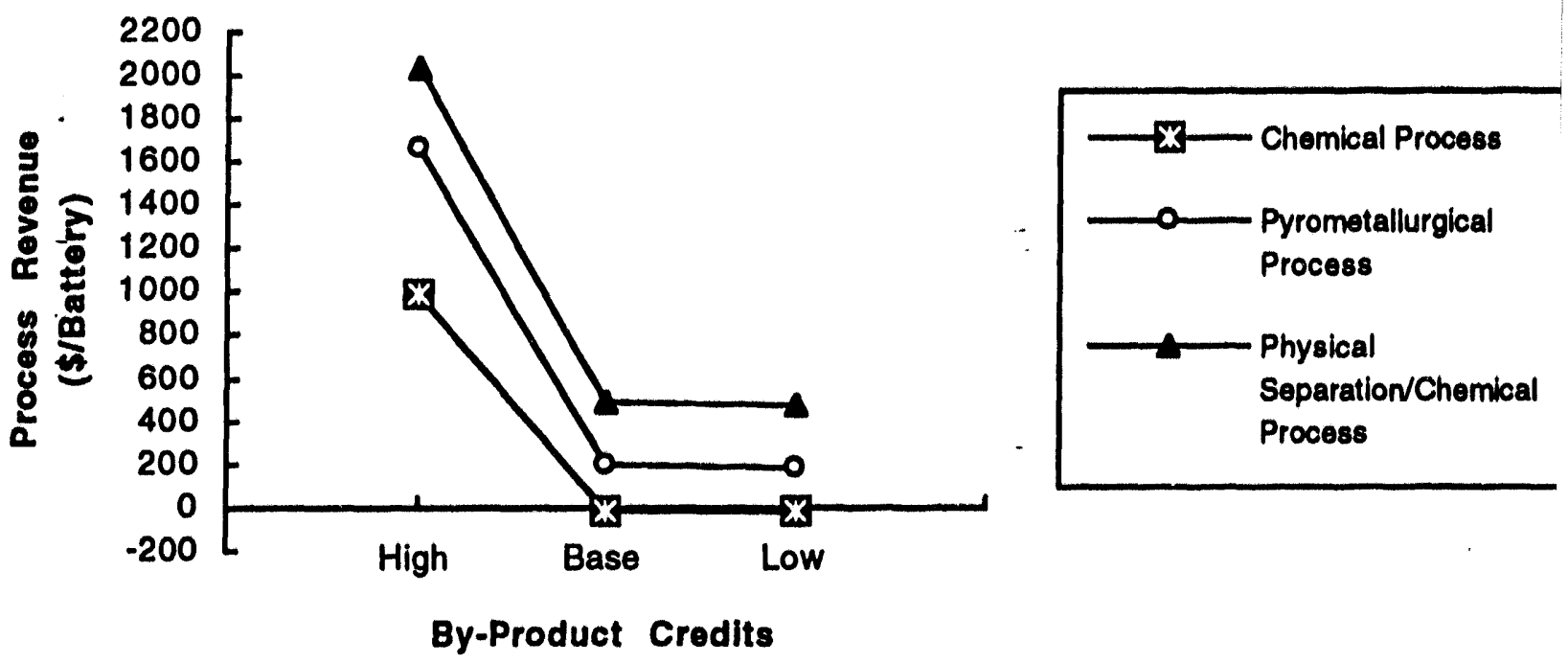

Figure 5-2: Impact of electricity cost on AB2 process operating cost
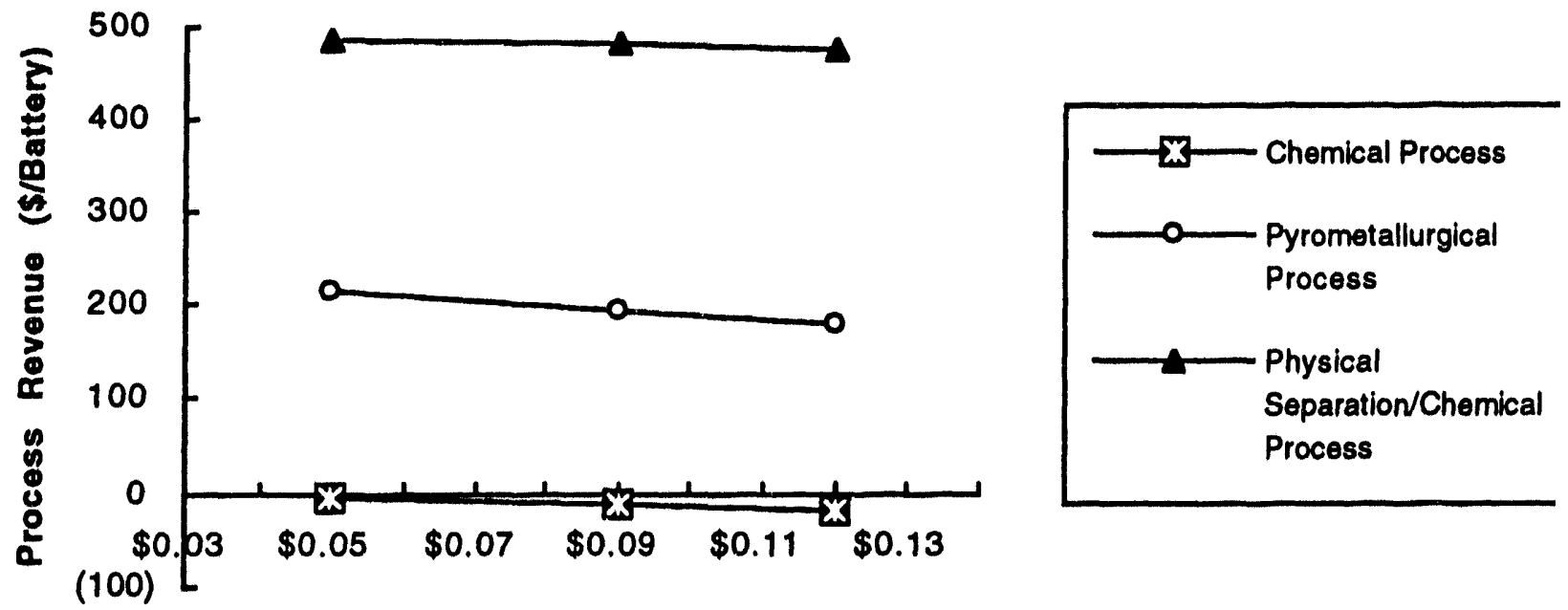

Electricity (\$/Kwh) 
Figure 5-3: Impact of capital investment on AB2 process operating cost

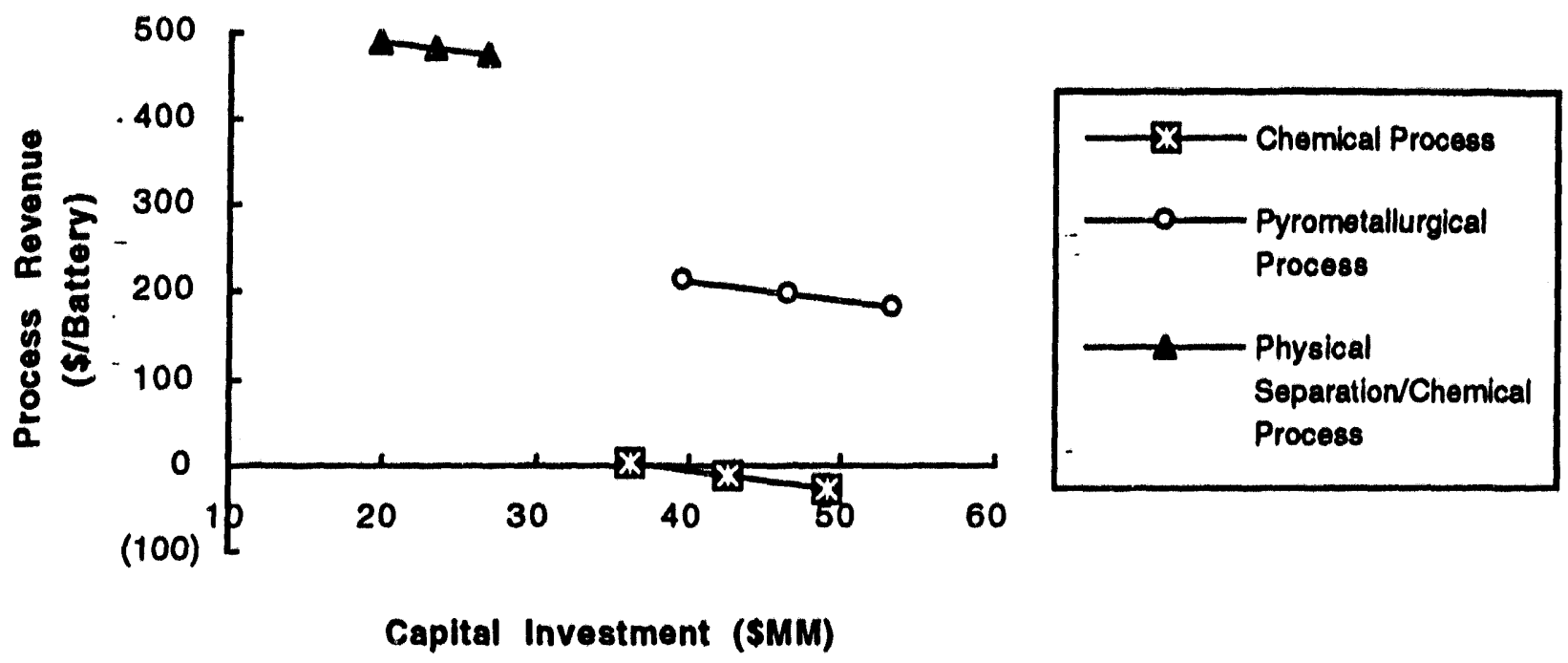

Figure 5-4: Impact of interest rate on AB2 process operating cost

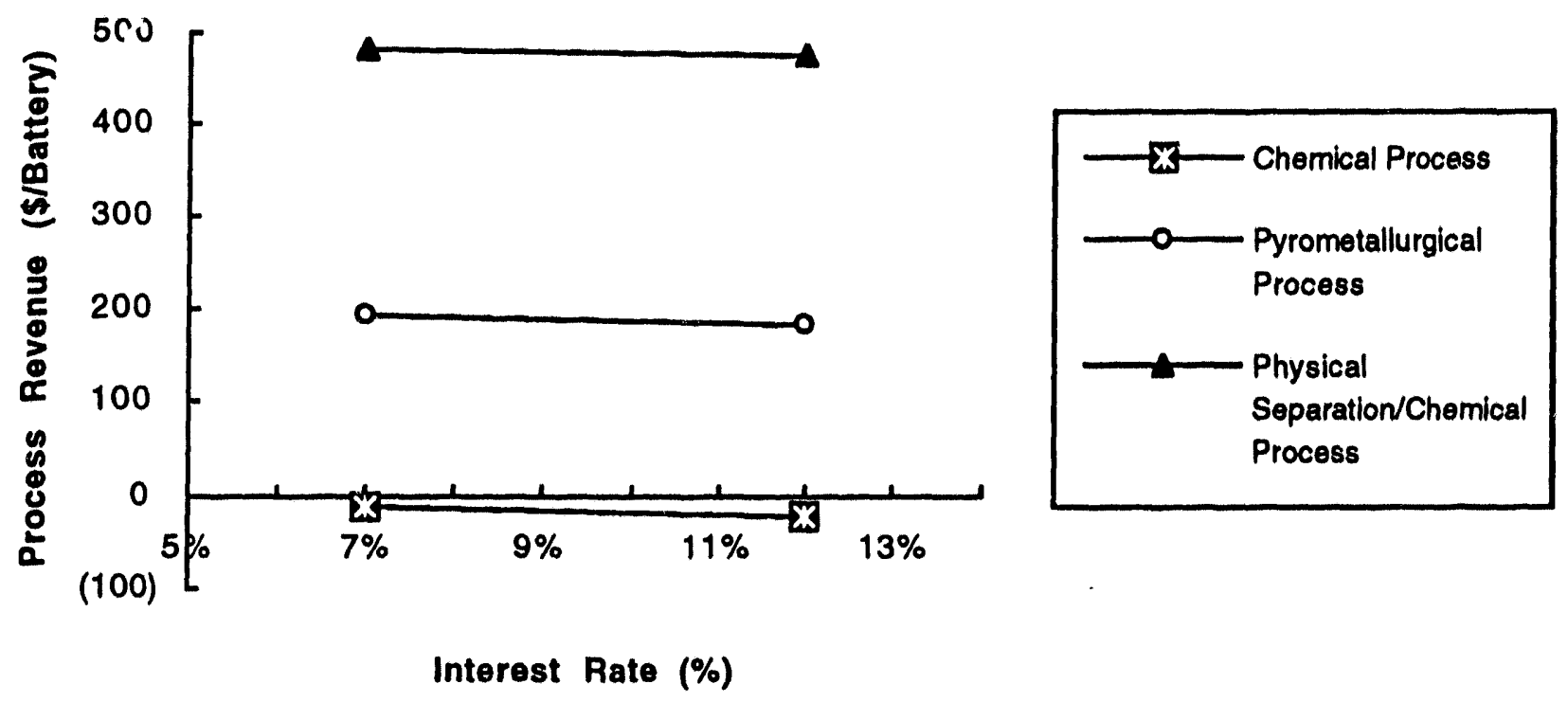


Figure 5-5: Impact of by-product credits on AB5 process operating cost

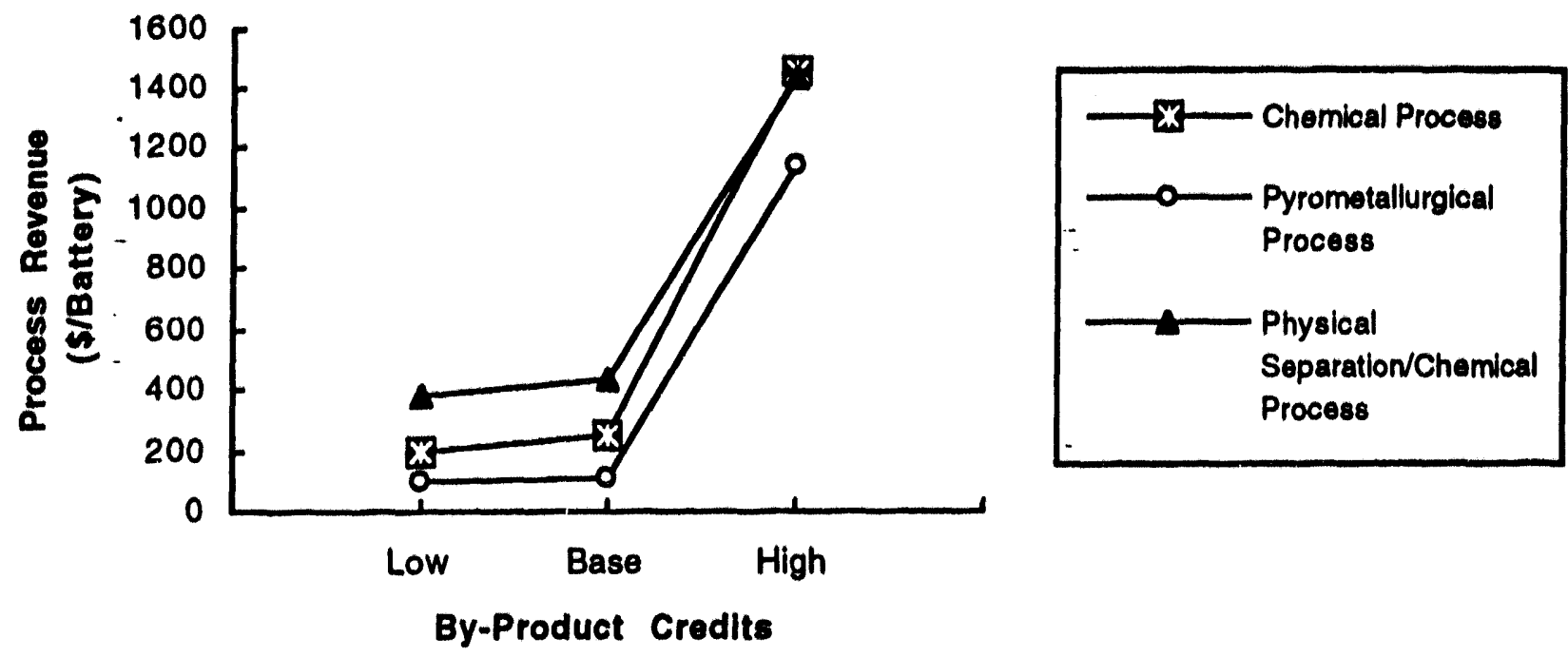

Figure 5-6: Impact of electricity cost on AB5 process operating cost
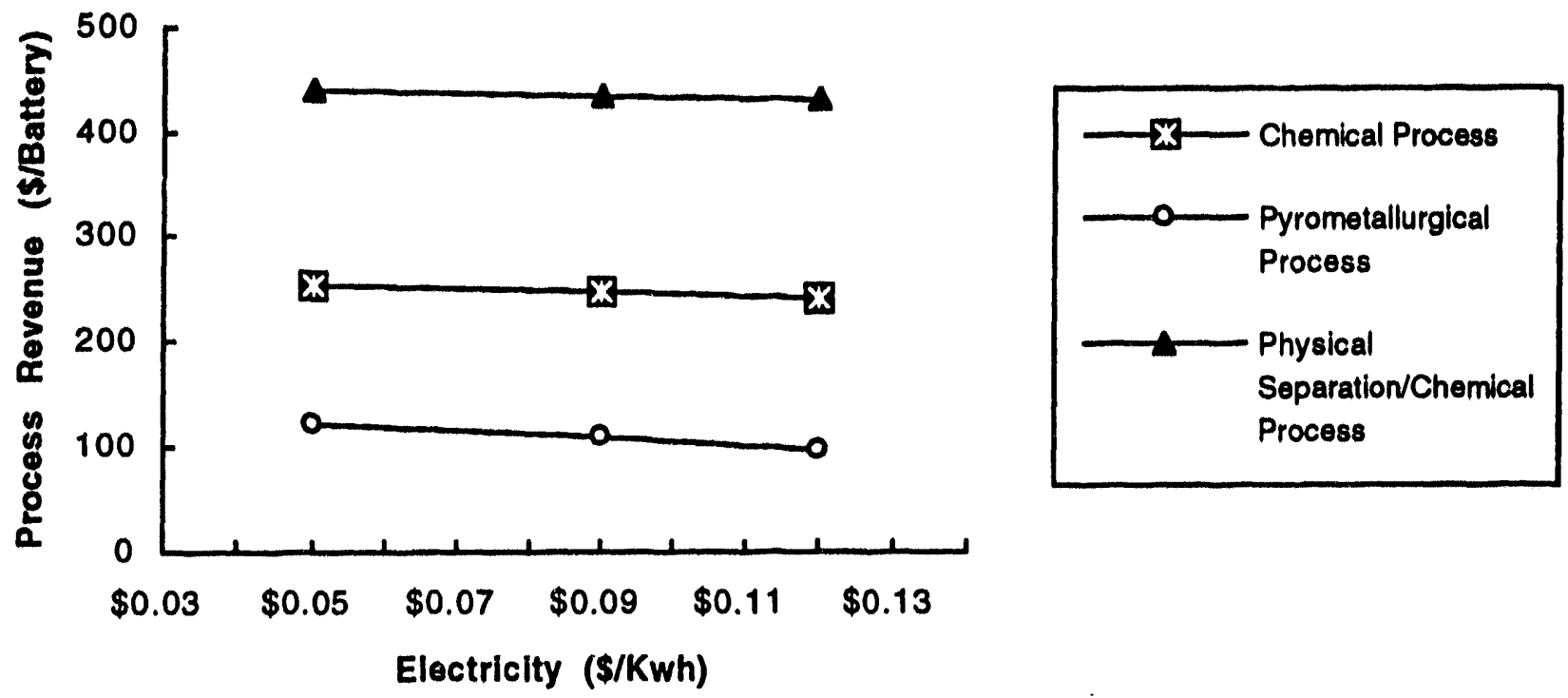
Figure 5-7: Impact of capital investment on AB5 process operating cost

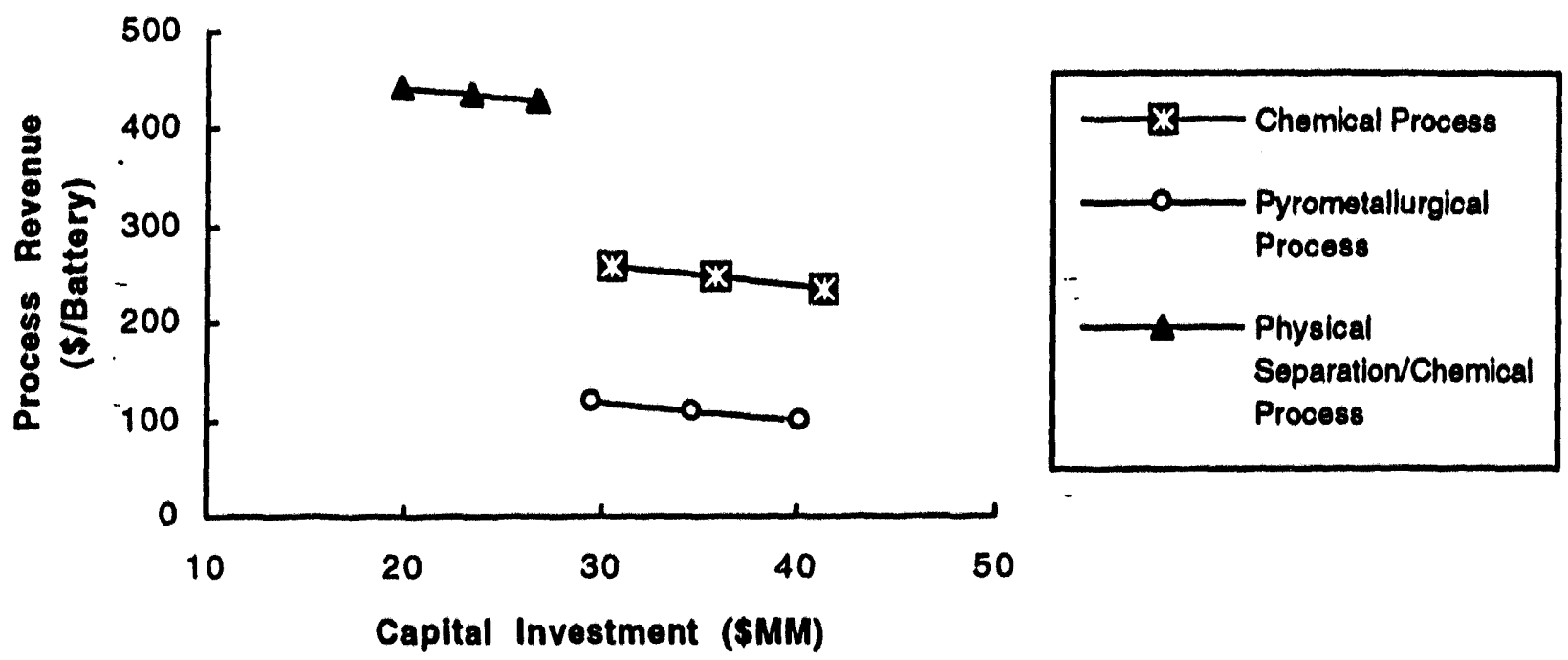

Figure 5-8: Impact of interest rate on AB5 process operating cost

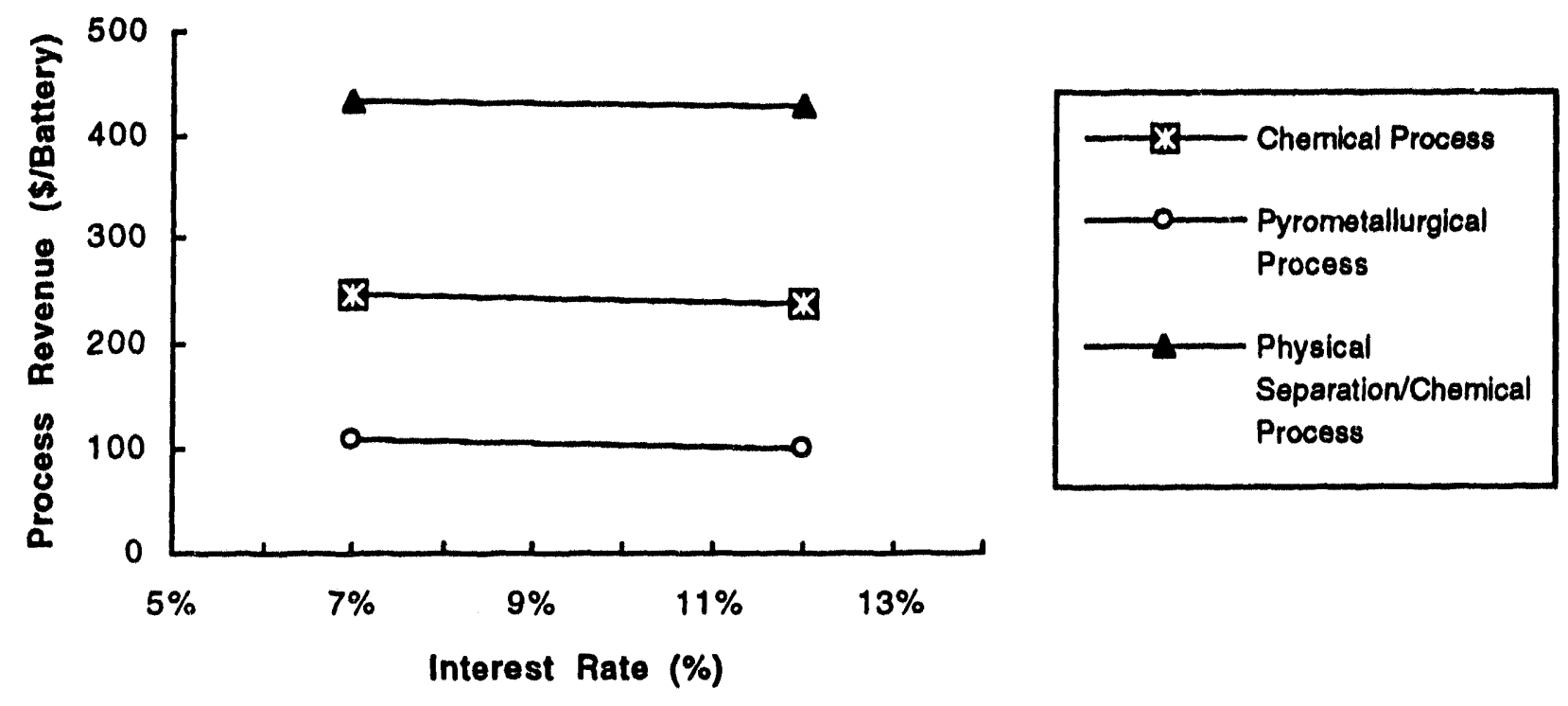




\subsection{Markets for Reclaimed Battery Materials}

\subsection{Introduction}

As part of a study of process feasibility, it is of equal importance to identify the possible outlets for reclaimed materials. The entire basis of the recycling processes described in Sections 4 and 5 must be the market for reclaimed materials. Clearly, producing a product with no market is not to be considered. Therefore, a parallel effort was made to determine possible outlet markets for the reclaimed materials. Some of the markets are quite large, and the reclaimed materials can easily be sold to them, while some markets are more difficult to enter. Our approach was to identify candidate markets for reclaimed materials and to better understand the limitations on salability posed by various impurity levels, market size, major players, expected growth rates, and price fluctuations. As shown in Section 5.0, recent historic fluctuations in prices of the by-products severely affect the revenue generation of each process.

Following is a discussion of possible outlet markets for the reclaimed materiais.

\subsection{Steel Scrap}

Each of the processes described previously will generate steel scrap as a product. The steel will be plated with nickel for corrosion protection. The product of the recycling process will be nickelcoated steel, estimated to be up to 3 percent nickel by weight. The nickel content of steel scrap is important in selecting possible outlets for the scrap. Most nickel is used in the production of stainless steel, generally with a nickel content of at least 8-10 percent nickel. Because the steel generated by the process is limited in nickel content, it is best to attempt to sell the scrap to carbon steel producers.

For a steel company to accept the recycled steel scrap, the company must accept that the nickel content is not a hindrance to their product. The steel companies would be diluting their production streams rather than adding nickel units by introducing nickel metal hydride battery case scrap. Therefore, steel scrap from the recycling process would at best receive the market price for \#1 heavy-melting steel scrap, which currently sells for approximately $\$ 120$ per metric ton in the United States. Figure 6-1 shows the historic \#1 heavy-melting steel scrap price.

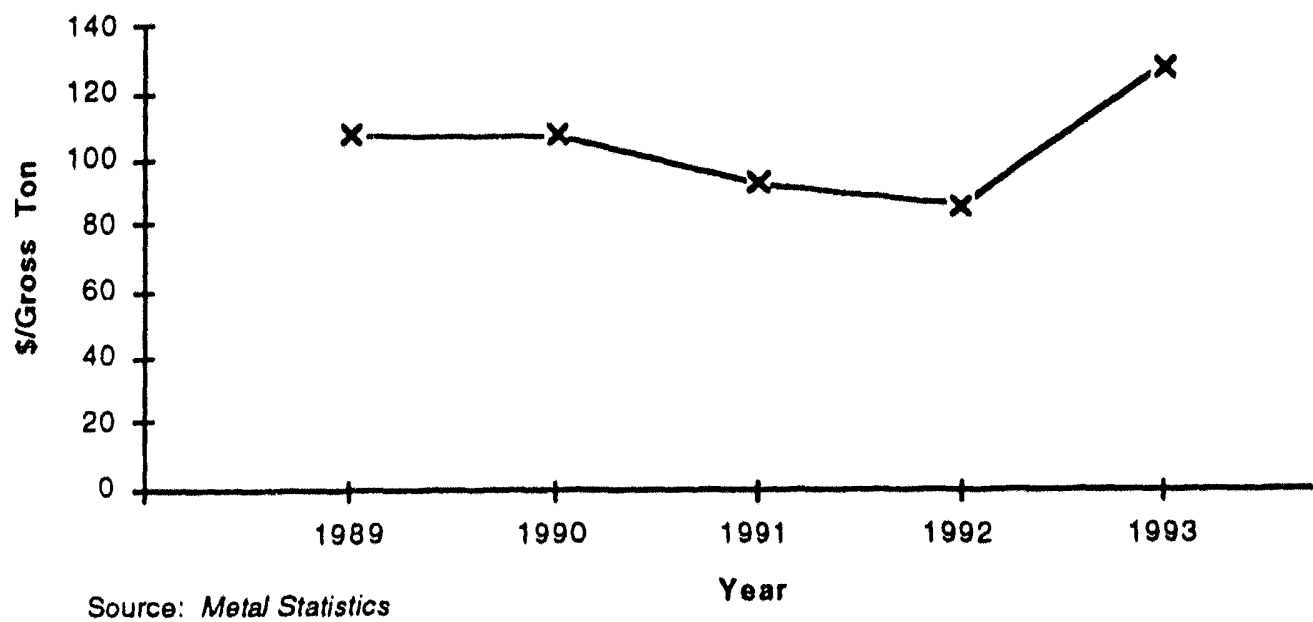

Figure 6-1: Historic Heavy Melting Steel Scrap Price 
The key impurities controlled by carbon steel producers in steel scrap are: copper, nickel, tin, molybdenum, and chromium. The steel scrap products from the recycling process will not contain any control elements except nickel. Nickel must be controlled, but possible alloy stcel applications are possible.

Current U.S. domestic consumption of steel scrap was estimated at 64.3 million metric tons in 1992 (USBM, 1993). The major consumers for steel scrap are the steel and ferrous casting industries. Demand increased slightly in the United States in 1992. The United States exported 9 million tons of steel scrap in 1992.

There are users of steel scrap in almost every state, but the major users are located in the midwest and southeast regions. Major purchasers of steel scrap include USX, Bethlehem Steel, Inland Steel, Nucor, Oregon Steel Mills, and Co-Steel. Steel scrap is generally sold by scrap brokers and recyclers such as the David Joseph Company and Proler.

\subsection{Nickel Metal}

The second major product of the recycling of nickel metal hydride batteries will be nickel, in the form of nickel metal, ferronickel, (an alloy of iron and nickel), or in the form of a nickel salt (e.g., chloride, sulfate, and carbonate). U.S. nickel consumption in 1992 was estimated at 145,000 metric tons (USBM, 1993). Ferronickel demand is approximately 15,000 metric tons per year nickel content. Ferronickel is used in the production of various specialty steels, including stainless, alloy, and tool steels. Secondary nickel-bearing materials are sold in the form of iron-nickelchromium alloys and crude nickel sulfate. Table 6-1 shows the U.S. consumption of nickel materials.

Table 6-1. U.S. nickel consumption by form based on nickel content

\begin{tabular}{|l|r|r|}
\hline & \multicolumn{1}{|c|}{1990} & \multicolumn{1}{c|}{1991} \\
\hline & Metric Tons & Motric Tons \\
\hline Primary & & \\
\hline Metal & 82,831 & 74,220 \\
\hline Cathodes \& Pellets* & 47,421 & \\
\hline Briquets \& Powders & 14,288 & \\
\hline Ferronickel** & 17,351 & 13,945 \\
\hline Oxide and oxide sinter & 5,577 & 3,218 \\
\hline Salts & 957 & 1,298 \\
\hline Other & 4,504 & 5,950 \\
\hline Total Primary & 111,221 & 98,631 \\
\hline Secondary (Scrap) & 33,709 & 32,520 \\
\hline Total & 144,930 & 131,151 \\
\hline
\end{tabular}

* The metal form is sold at $99.5 \%$ purity. Thus, the gross consumption of cathodes and pellets estimated based on 1990 figures is 47,659 metric tons.

** Ferronickel is sold at 48-52\% purity. Thus, the gross consumption estimated based on the 1990 figure is 10,726 to 11,619 metric tons.

*** Includes batteries, ceramics, and other alloy-containing nickel.

Source: U.S. Bureau of Mines

Ferronickel prices are based on the fraction of nickel contained in the alloy. The current nickel price is near the historic low. However, there is optimism that the price will increase in the near 
future. There is significant material now entering the U.S. market from Russia, aggravating the price decline. However, demand in the United States and the Asian Pacific markets is increasing, and the price should begin to increase with the increase in nickel demand.

The main market for ferronickel recovered from batteries would be in stainless steel production. Most companies have multiyear, long-term contracts. The current nickel price is $\$ 2.15$ per pound (October, 93), and is shown with the historic nickel prices in Figure 6-2. The production from the pyrometallurgical process will not overwhelm the U.S. market, but will require several producers to absorb the volume. Growth in stainless steel demand is expected to be at least two to three percent annually in the United States in the foreseeable future.

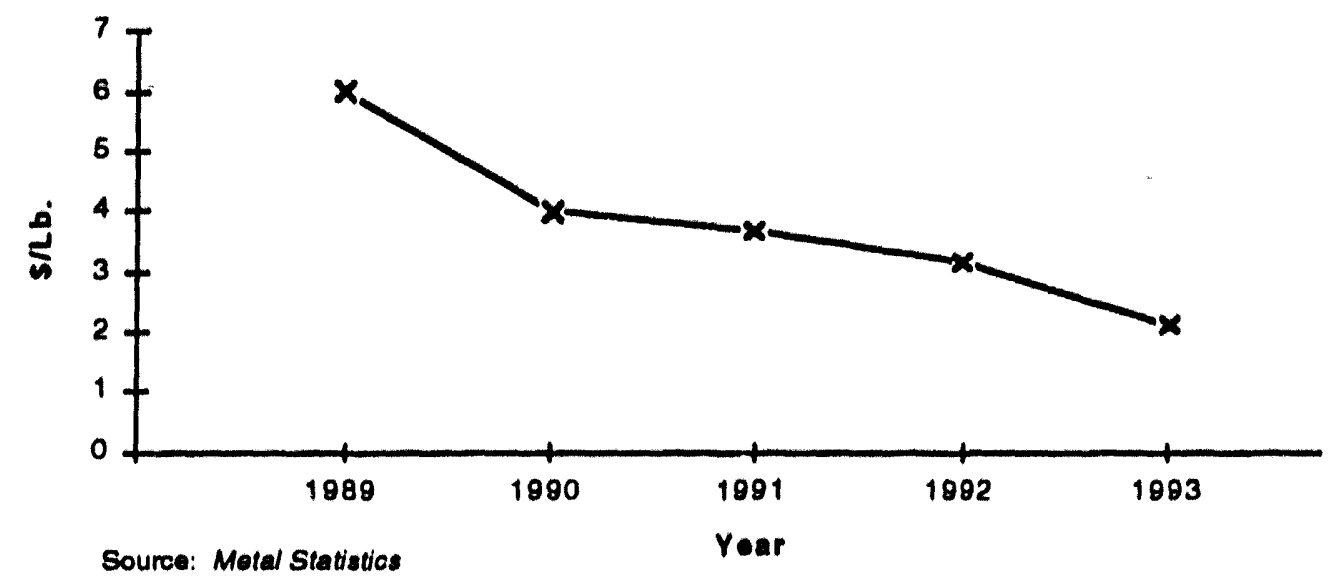

Figure 6-2: Historic nickel cathode price

Key impurities to be controlled in ferronickel are:

$\begin{array}{ll}\text { Vanadium } & 0.03 \% \\ \text { Silicon } & 0.7 \% \\ \text { Titanium } & 0.05 \% \\ \text { Cobalt } & 0.1 \%\end{array}$

Major purchasers of ferronickel include Allegheny Ludlum and Washington Steel Company.

\subsection{Nickel Salts}

Nickel salts make up another class of nickel materials which could be recovered from batteries. The U.S. demand for nickel salts by end use application is shown in Table 6-2. Some of the demand data is proprietary and could not be obtained, but the demand for the nickel salts in these applications is expected to be small. 
Table 6-2. U.S. Nickel Salt Consumption by Use Based on Nickel Content

\begin{tabular}{|l|c|c|}
\hline & 1990 & 1091 \\
\hline Use & Metrle Tons & Motrlo Tons \\
\hline Electroplating & Withheld & 232 \\
\hline Cast iron & Withheld & Withheld \\
\hline Chemicals and chemical uses & 26 & Withheld \\
\hline Stainloss and heat-resistant steel & Withhold & Withhold \\
\hline Other & 931 & 1.066 \\
\hline Total Consumption & 957 & 1,298 \\
\hline
\end{tabular}

Source: U.S. Bureau of Mines

\subsubsection{Nickel Chloride}

World demand for nickel chloride is approximately 8,000 metric tons. The leading producing countries are France and Finland, accounting for approximately 90 percent of the production. The nickel chloride price has declined in response to the declining nickel value. There are no new applications for nickel chloride in the near future, and no additional suppliers appear to be emerging to compete in this market. The combined production of France and Finland should be sufficient to meet market demands.

\subsubsection{Nickel Sulfate}

U.S. demand for nickel sulfate was 2,800 metric tons in 1992. Belgium and Finland are the principal producers, accounting for 36 and 30 percent of U.S. demand, respectively. The import quantities have remained essentially unchanged for several years. No nickel sulfate crystal is currently produced domestically. Most of the products sold in this market are supplied in the crystal form.

Some nickel sulfate is sold as solution, and the volume is approximately 1,350 metric tons. The most prominent application for nickel sulfate solution is for electroless nickel-plating solutions.

There is a plentiful supply of this product. The struggle for market share between the largest suppliers, and the downward trend of nickel prices worldwide, has led to a decline in the price of nickel sulfate in the past year.

\subsubsection{Nickel Carbonate}

Many specialty grades of nickel carbonate are supplied to the market. The market is dominated by two or three major producers. The current U.S. demand for nickel carbonate is approximately 550 metric tons per year. Traditional applications are metal finishing and $\mathrm{pH}$ control. A new application is the use of nickel carbonate as the nickel source for a nickel-zinc electrogalvanizing process.

\subsubsection{Market Options for Nickel Materials}

Both the nickel chloride and sulfate markets are small and mature with no new outlets for the products. Nickel carbonate may be an interesting alternative with the growing application of nickelzinc electrogalvanizing. Unfortunately, the purity requirement for electrogal vanizing is very stringent; the recycled product recovered as a precipitated nickel salt would have difficulty meeting the specifications.

Based upon discussions with nickel buyers, there is divided opinion as to how this material can be used. One option would be that the nickel salt companies would buy the product in solution from the recycling plant, and then refine the material and sell it to the end users. A second option would be that nickel producers would buy solid nickel carbonate from the recycling plant and use it as a raw material to recover the nickel. 
Even though the nickel salt markets are small, mature, and dominated by European producers, some North American producers have demonstrated interest in the recycled product. They would prefer to refine the nickel salt-containing solution themselves. The battery recycling plant would need to supply the nickel salt in solution after separating out most of the contaminants. The estimated impurities levels from the processes described in Sections 4 and 5 indicate that the nickel material would be within the acceptable ranges for the chemical companies. Although the vanadium concentrate from the $\mathrm{AB}_{2}$ batteries is at a higher concentration than the normal!y accepted range, simple process adapations could be made to accommodate the recycled product.

In a small market dominated by foreign producers, the nickel salt product from the nickel hydride battery recycling process would induce tremendous supply pressure on the markets. A major nickel product company has indicated a preference to recover only the nickel from the nickel salts as raw material for nickel metal production. Nickel carbonate would be the preferred product. In general, chlorides and nitrates are not desirable for this purpose, and sulfates would require low sodium content restrictions.

\subsection{Vanadium}

Vanadium is recovered as a by-product by six plants in the United States. Vanadium is recovered from phosphate and steel slags, spent catalysts, petroleum residues, and utility ash. The major market for vanadium is steel production, accounting for over 85 percent of demand. The total U.S. consumption of vanadium, chiefly as ferrovanadium, was 3,800 metric tons in 1992 (USBM, 1993).

China is the largest producer, and South Africa is second. The U.S. market relies largely on imported supplies to meet its demands. Price pressure because of significant imports from the former Soviet Union has reduced the price. Vanadium is supplied as an 80 percent vanadiumferrovanadium alloy. The current price is about $\$ 4.00$ per pound, depending on vanadium content. The historic vanadium price is shown in Figure 6-3. The specifications for ferrovanadium are as follows:

$\begin{array}{lll}\text { Carbon } & 0.75 \% & \text { maximum } \\ \text { Aluminum } & 2 \% & \text { maximum } \\ \text { Silicon } & 2 \% & \text { maximum }\end{array}$

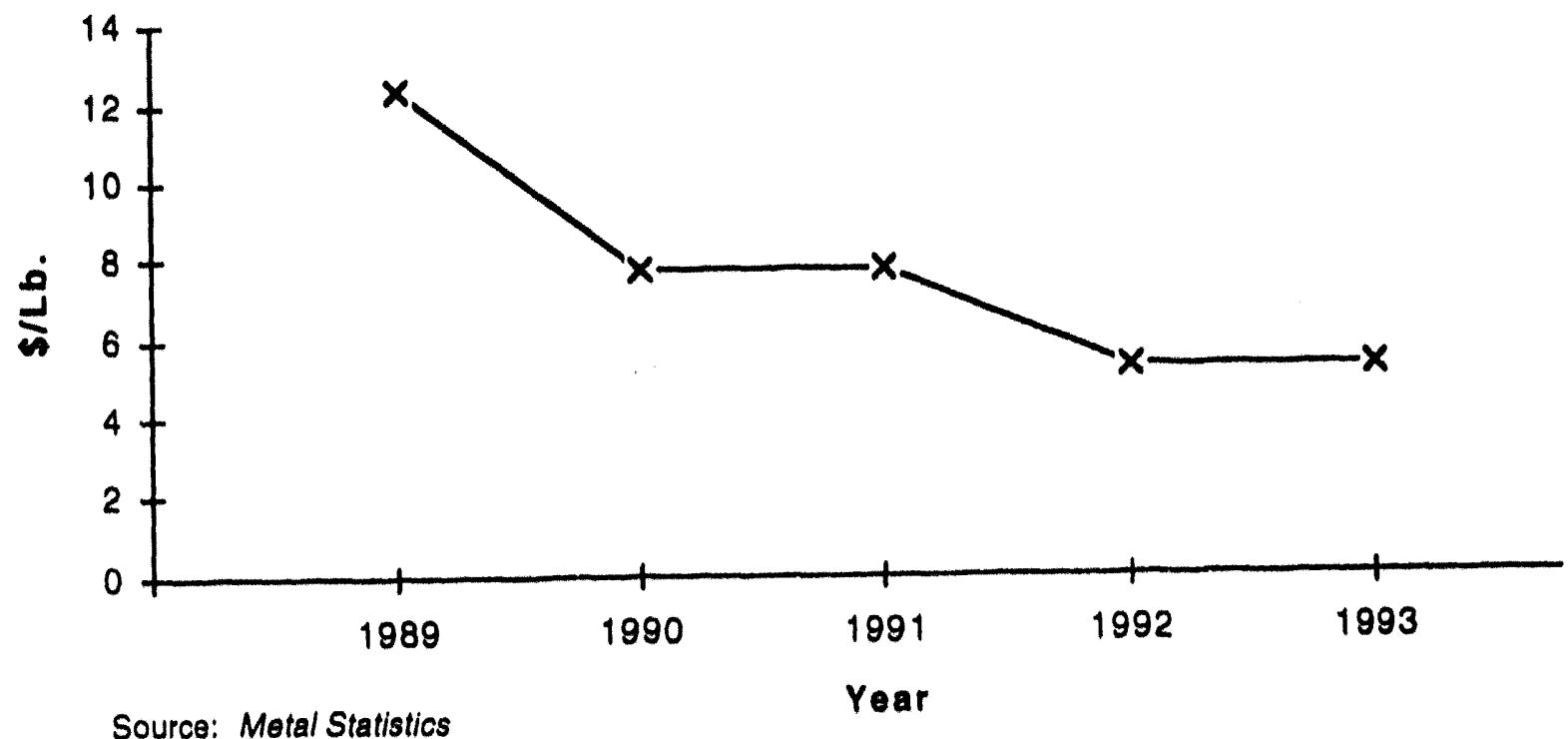

Figure 6-3: Historic Vanadlum Price 


\subsection{Titanlum Compounds}

Possible markets for titanium compounds were reviewed. The only major use for titanium is in the production of titanium dioxide. The two processes for manufacturing pigments using titanium dioxide have very different raw material specifications. For the chloride process, very pure, very high quality titanium dioxide is required. There are strict material specifications for chloride processing of titanium dioxide. For example, the combined concentrations of magnesium and calcium cannot exceed $0.25 \%$ by weight, yet both may be found in process slags from the pyrometallurgical process for $A B_{2}$ nickel metal hydride battery products. The recycled product would not be able to meet that standard.

The other process, the sulfate process, requires a titanium dioxide source which is dissolvable in sulfuric acid. Some slags from pig iron production are used as the raw material for the sulfati process. The titanium dioxide content tends to be in the $80-85$ percent range. However, materials with titanium dioxide content as low as $65-70$ percent may be used. The material recovered from batteries does not meet the concentration standards either. The applicable specifications of impurities in titanium dioxide are:

$\begin{array}{lll}\mathrm{Cr} & 0.5 \% & \text { maximum } \\ \mathrm{V} & 0.5 \% \text { maximum }\end{array}$

$\mathrm{Al}_{2} \mathrm{O}_{3}, \mathrm{SiO}_{2}$, and $\mathrm{ZrO}_{2}$ can be tolerated to a reasonable limit

Iron is advantageous in titanium dioxide concentrates. The impact of nickel and cobalt is unknown, because these metals are not typical contaminants.

The price for titanium dioxide concentrates ranges from $\$ 200$ to 500 per metric ton, depending on the concentration of titanium. The current supply surplus is beginning to slowly turn around, because the price dropped considerably. The demand will remain steady, growing at two to three percent a year. U.S. consumption in 1992 is estimated at 1.05 million metric tons (USBM, 1993).

\subsection{Zirconium Compounds}

Zirconium oxide is used by the refractory industry to produce glass refractories. Most companies purchase pure materials and blend them. The recycled battery product slag would be a mixture of zirconia, alumina, silica, and calcia.

Glass refractory manufacturers only consider recycled material when a shortage of supply occurs. Recycling of refractories in the glass industry is only a small percentage of total production (5-10 percent) because $c f$ concerns in variability and consistency.

The recycling of refractories by manufacturers is provided more as a service to their customers to help handle the waste of eroded refractories. The recycled refractories are much better raw materials to glass refractory companies than the by-product slag from recycling nickel metal hydride batteries, which would not meet the requirement of very low calcium oxide content (much less than one percent).

An alternative to this material would be to supply the recycled slag as aggregate material to the cement industry.

\subsection{Rare-Earth Metals}

Rare-earth metal compounds are acceptable as synthetic ores or concentrates in three forms: nitrate solution, carbonate cake, and hydroxide. Ores exist mostly with very high purity rare-earth metals. 
The carbonate requires a specification of less than I percent impurity combined. The hydroxide requires 50 percent metal content. U.S. consumption of rare-earth compounds was approximately 15,7(K) metric tons in 1992. The United States is a net exporter.

Chemical compound end uses typically require a purity of 98 percent. Elements are sold at 96 percent or higher purity. It is expensive to separate rare-carth mixtures because of their similar chemical behaviors. Therefore, selling the rare earths as a misch metal oxide or hydroxide is the only possibility for marketing the reclaimed materials.

Typically, raw materials taken in by the refiners are concentrated. Pure metals are more valuable than mixtures, and some rare-earths are more valuable than others. Of the rare earth combinations in the recycled product, cerium and neodymium are the high value metals. However, these two products are present in substantially lower concentrations than lanthanum and praeseodymium. Aluminum hydroxide is an undesirable impurity. The rare-earth metals producers in the United States do not think the recycled products would be worthwhile raw materials for them to pursue without additional processing.

The alternative to marketing the recycled rare earth to misch metal manufacturers also does not seem very good. As the misch metal market is dominated by China. China has half the world's rare-carth reserves and has low manufacturing costs. Only a few domestic misch metal suppliers remain.

\subsection{Potasslum Compounds}

It is likely that any potassium recovered from the recycling processes will be in the form of potassium chloride. The major end use of potassium chloride is fertilizers. Agricultural end uses account for $94 \%$ of the potassium chloride demand. The balance is used as raw materials for producing other potassium chemicals.

Potassium chloride is a commodity chemical and price is very volatile. Currently, the market is in oversupply. U.S. consumption of potash (potassium carbonate) was 5.4 million tons in 1992.

Seventy-five percent of potash is converted to potassium chloride. The recycled potassium chloride product could be sold locally for agricultural uses. Typical potash ores range from 12 to $23 \mathrm{~K}_{2} \mathrm{O}$ content. The high sodium chloride concentration of the reclaimed materials causes concern for the acceptability of the recycled product. To meet market needs, potassium hydroxide may be needed instead of sodium chloride to neutralize the acid in the chemical processes for batteries, in order to make the material more attractive to potassium chloride users. 


\subsection{Generic Design Criteria}

The following design criteria will make the nickel metal hydride battery easier to recycle:

- simplicity in the electrode geometry

- limitations on the number of different plastics used

- limitations on the use of iron in the electrodes

- prevention of the use of copper in any part of the battery where it would be difficult to separate from the nickel and iron materials

- care should be taken to reduce the contamination of the hydride electrode with iron or copper

- careful use of organic materials in the electrolyte.

The basic design of the nickel metal hydride electric vehicle battery used throughout this study was one utilizing parallel plate electrodes. This design was chosen because of the ease of separation of the electrode: it would be much more difficult to dismantle the battery if it had a different design, such as the "jelly roll" (round) design.

We have assumed that the only plastic found in the battery is polypropylene. This is common practice in lead-acid batteries and makes the battery plastics easier to recycle. If mixed plastics are used in the nickel metal hydride batteries, the recycling of the plastics is much more difficult. As seen in the recycling of automobiles, mixed plastics are almost impossible to recycle. In addition, if chlorinated plastics (e.8., PVC) are used, possible dioxin formation would complicate any thermal process design, requiring significant additional investment in separation technology.

Iron is a difficult contaminant to separate from nirkel chemically. As described earlier, the separation of the iron from the nickel is extremely expensive in pyrometallurgical processes and adds several steps in the chemical processes. In addition, the iron may become a difficult compound to dispose of.

Copper is very detrimental in the production of steel products, and steel makers are very careful to limit the copper content of their products to less than 0.2 percent: in the case of some alloys, 0.01 percent may be too high. Therefore, if copper is allowed to enter the battery, disposition of the battery materials to the steel industry is highly uncertain.

Contamination of the hydride alloy with copper makes it more difficult to reclaim because of the need to produce products which are suitable for the steel industry. Again, copper could make it extremely difficult to dispose of the reclaimed materials. In addition, if the current collectors and electrode substrates are to be changed to a more conductive material, then aluminum would be preferred to copper from a recycling viewpoint. This is because in most of the processes discussed, aluminum would become a treatable waste material which would have little impact on the quality of the produst, while copper could be extremely difficult to separate.

Certain organic materials (e.g., polymers or starches) added to the electrolyte may significantly affect the cost of treatment of the electrolyte, and may increase the cost of water treatment significantly. In addition, disposal of the water treatment sludge could be highly dependent on the materials added to the electrolyte. As described earlier, the recovery of salt from the chemical process for sale significantly affects the process economics. If the sal ts have to be treated as a hazardous waste, the impact on the process costs would be significant. 
Finally, if the battery case could be changed to polypropylene from nickel-plated atcel, it would both reduce the processing cost slightly, and assist in the reduction of weight of the battery. 


\subsection{Future Work}

There are numerous questions about the possible recycling routes for battery materials. It has been our intent here to evaluate possible routes for recycling of nickel metal hydride batteries. Although some of our assumptions may not be consistent with current battery designs, we based our assumptions on possible generic battery design and chemical composition, which allow for possible recycling alternatives to be evaluated. The final definition of a process for nickel metal hydride battery recycling will be based upon the ultimate commercial battery system design and chemistry.

However, each battery system evaluated and each process reviewed does indicate that the battery materials can be recovered economically. Obviously, there are several assumptions which lead to this conclusion, including:

- the design and final form of the battery system

- the possible outlet markets actually accepting the battery materials

- the ability to dispose of the process residues without the residues being classified as hazardous waste

- the behavior of the materiais in these processes

- the process yields and impact of impurities

- the range of possible hydride alloys.

Therefore, future work related to recycling of nickel metal hydride electric vehicle batteries must include:

- verification of the battery compositions

- chemical assays of the EV cells

- laboratory and pilot-scale investigation of the possible recycling options

- chemical and engineering evaluation of process fundamentals

- equipment specifications to be developed

- engineering design of the recycling plant

- review of recovered products and market opportunities

- review of process costs

In addition, full evaluation of market acceptance for the reclaimed materials must be done. Clearly, samples of possible reclaimed products and estimates of generation rates are needed so that actual customers for the reclaimed battery materials can be approached. Samples are needed to ascertain the acceptance of the reclaimed products and the price for the materials.

All of these issues must be addressed before final design of a process plant for the recycling of nickel metal hydride batteries can be undertaken. 


\subsection{Bibliography}

Aldorf, Henry, Moly Corp., private conversation, October 1993.

Annual Publication of Metal Finishing Suppliers Association, 1993.

Braun, John, Allegheny Ludlum, private conversation, October 1993.

Brock, Ben, Allied Hunter Co., private conversation, October 1993.

Chapman, Frank, John Florio, Cohart Refractories, private conversation, October 1993.

Chemical Engineer's Handbook, 5th Edition, McGraw Hill, New York, NY, 1973.

Cope, Scotf, SKW Metals and Alloys, private conversation, October 1993.

Daily, Dan, David Joseph Co., private conversation, October 1993.

David, J., "Cadmium and Nickel Battery Treatment - An Economic Point of View," presented at the First International Seminar on Battery Waste Management, Deerfield Beach, Florida, November 1989.

David, Jacques, SNAM/SAVAM and Patrick Archier, private conversation, April 1992.

David, Jacques and SNAM/SAVAM, private conversation, September 1993.

Edelstin, Phil, Frank Strzelec, CP Chemicals, private conversation, October 1993.

Evaporation Maps For The United States, United States Department of Commerce, Washington, D.C., 1959.

Feldman, R., "Economics of Plant Startups," Chemical Engineering, November 3, 1969.

Fetcenko, Michael A., et al., "Alloy Preparation of Hydrogen Storage Materials," U.S. Patent No.4,948,423, for Energy Conversion Devices, Inc., August 14, 1990.

Fetcenko, Michael A., et al., "Electrode Alloy Having Decreased Hydrogen Overpressure and/or Low Self-Discharge," World Intellectual Property Organization, International Publication No. WO 93/04508, March 4, 1993.

Fetcenko, Michael A. et al., "Method for the continuous fabrication of comminuted hydrogen storage alloy material negative electrodes," European Patent Application

No. 0405112 A1, September 10, 1991.

Fujimori, M, et al., "Electrowinning From Aqueous Chlorides In SMM's Nickel and Cobalt Rfining Process," Chloride Electrometallurgy, P. Parker, ed., The Metallurgical Society of AIME, Warrendale, PA, 1982.

Guthrie, K., "Capital Cost Estimating," Chemical Engineering, March 24, 1969.

Guthrie, K., "Estimating the Cost of High-Pressure Equipment," Chemical Engineering,

December 2, 1968. 
Hall, R., et. al., "Estimating Process Equipment Costs," Chemical Engineering, November 21, 1988.

Hara, T., N. Yasuda, "New Binding Materials for Metal Hydride Electrodes which Permit Good Recycleability," J. Electrochem. Soc., Vol. 140, No. 9, September 1993.

Hester, Frank, Kemira Inc., private conversation, October 1993.

Hill, Jim, AP Green, private conversation, October 1993.

"INMETCO Recycles Spent Batteries," Railway Age, March 1991.

"INMETCO Battery Management Seminar," reference materials, February 11, 1992.

Kleine, Lee, Carpenter Technology Corp., private conversation, October 1993.

Krauskopf, Ulrich, Ore and Chemical Corp. private conversation, October 1993.

Kulik, Joe, North American Refractories, private conversation, October 1993.

Lackman, E.I. Du Pont, private conversation, October 1993.

Landolt, Carlos, Inco Ltd., private conversation, October 1993.

Lyman, J., Palmer, G. J. of Metals, May, 1993.

Matsumoto, Isao, et al., "A Sealed Nickel/Metal Hydride (Ni/MH) Battery System in Use for Electric Vehicles, Matsushita Battery Industrial Co., Ltd., Japan. Circa 1991.

McWilliams, Dean, New Mexico Potash Inc., private conversation, October 1993.

Metal Statistics 1993, American Metal Market, New York, NY, 1993.

Mineral Commodity Summaries 1993, United States Bureau of Mines, Washington, D.C., 1993.

Minerals Yearbook 1989, U.S. Department of Interior, Washington, D.C., 1989.

Minnesota Pollution Control Agency, "Household Battery Recycling and Disposal

Study," June 1991.

Morrow, Jeff, Frank Dittrick, Rhône Poulenc, private conversation, October 1993.

Mular, A., Mining and Mineral Processing Equipment Cost and Preliminary Capital Cost

Estimations, The Canadian Institute of Mining and Metallurgy, 1982.

Onuska, J., R. Hanewald, M. Schweers, "High-Temperature Metals Recovery of $\mathrm{NiCd} / \mathrm{Fe}$

Batteries," presented at the Third International Seminar on Battery Waste Management, Deerfield

Beach, Florida, November 1991.

Onuska, J., M.Schweers, P.A. Whitner, "Programs for Collecting, Packaging, Transporting, and Reclaiming Spent Nickel-Cadmium Batteries," presented at the Fifth Industrial Seminar on Battery Waste Management, Deerfield Beach, Florida, November 1993.

Ovonic Battery Company, "Material Safety Data Sheet-Ovonic Hydride Powder," May 1991. 
Ovshinsky, Stanford R., et al., "Electrolytic Cell Anode," U.S. Patent

No.4,537,674, for Energy Conversion Devices, Inc., August 27, 1985.

Pankratz, L.B., "Thermodynamic Properties of Elements and Oxides," United States Bureau of Mines Bulletin 672, Washington, D.C., 1982.

Petrov, Konstantin, et al., "Optimization of Composition and Structure of Metal-Hydride Electrodes," Texas A\&M University System. Circa 1992.

Praxair, Inc., "AOD Process," 1986.

Raymond Kaiser Engineers, Capital and Operating Cost Estimating System Handbook for Electrolytic Zinc Refining Facilities, for Bureau of Mines, August 1986.

Reichman, Benjamin, et al., "Activated Rechargeable Hydrogen Storage Electrode and Method," U.S. Patent No. 4,716,088, for Energy Conversion Devices, Inc., December 29, 1987.

Robiette, A.G.E., Electric Smelting Processes, John Wiley and Sons, New York, NY, 1973.

Schweers, Mark, J. Onuska, R. Hanewald, "A Pyrometallurgical Process for Recycling Cadmium Containing Batteries." (Circa 1991)

Schweers, Mark, INMETCO, private conversation, October 1993.

Silver, Mark, IMC America, private conversation, October 1993.

van Erkel, J., "Recycling of Metals from Spent Batteries," TNO research report No. 91-195, May 1991.

van Erkel, J., TNO, private conversation, April 1992.

Wilbert, Mac, North America Chemical Company, private conversation, October 1993.

Zimmerman, Vic, Hartstan, a Division of Chemtech, private conversation, October 1993.

1993 Directory of Chemical Producers, United States, SRI International, Menlo Park, California. 


\section{Appendix A}

Material Balance Calculations for The Individual Processes 


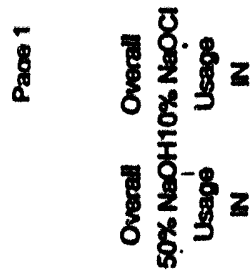

$$
\begin{aligned}
& \text { ะั ฐ } \\
& \text { รั่ } \\
& \text { 影骂 } \\
& \text { 突 }
\end{aligned}
$$

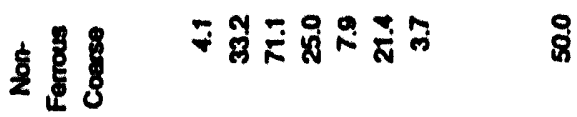

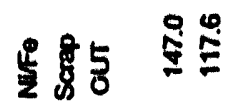

$$
\begin{aligned}
& \text { 漹 }
\end{aligned}
$$

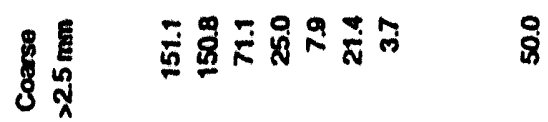

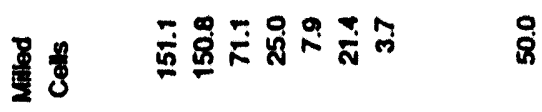

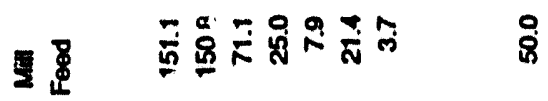

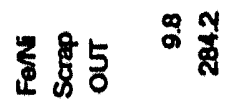

$$
\begin{aligned}
& \text { 㵙 } \\
& \text { 옴 } \\
& \text { 온 } \\
& \text { 옹 } \\
& \text { 용 } \\
& \text { 옹 } \\
& 8 \\
& \text { ํำ }
\end{aligned}
$$

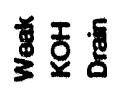

$$
\begin{aligned}
& \text { ฉิํํㅇำ } \\
& \text { 于 } \\
& \AA \\
& \text { ํㅗํ } \\
& 8 \\
& \text { 웅 } \\
& \text { \&̊ }
\end{aligned}
$$

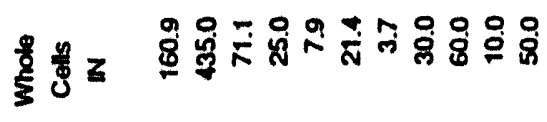

$$
\begin{aligned}
& \text { 总 } \\
& 8
\end{aligned}
$$

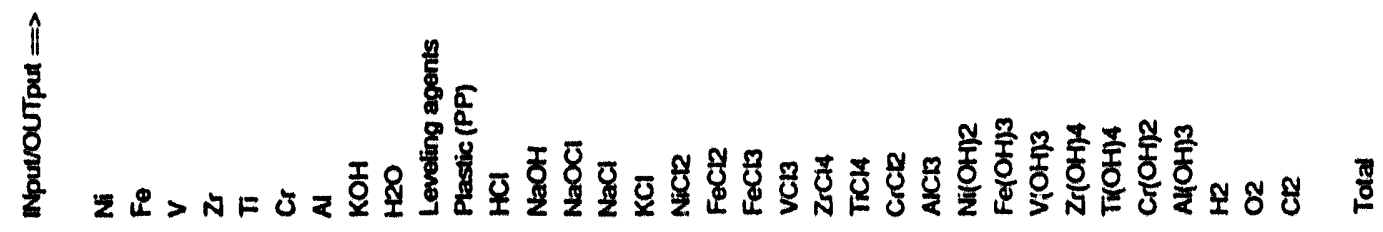




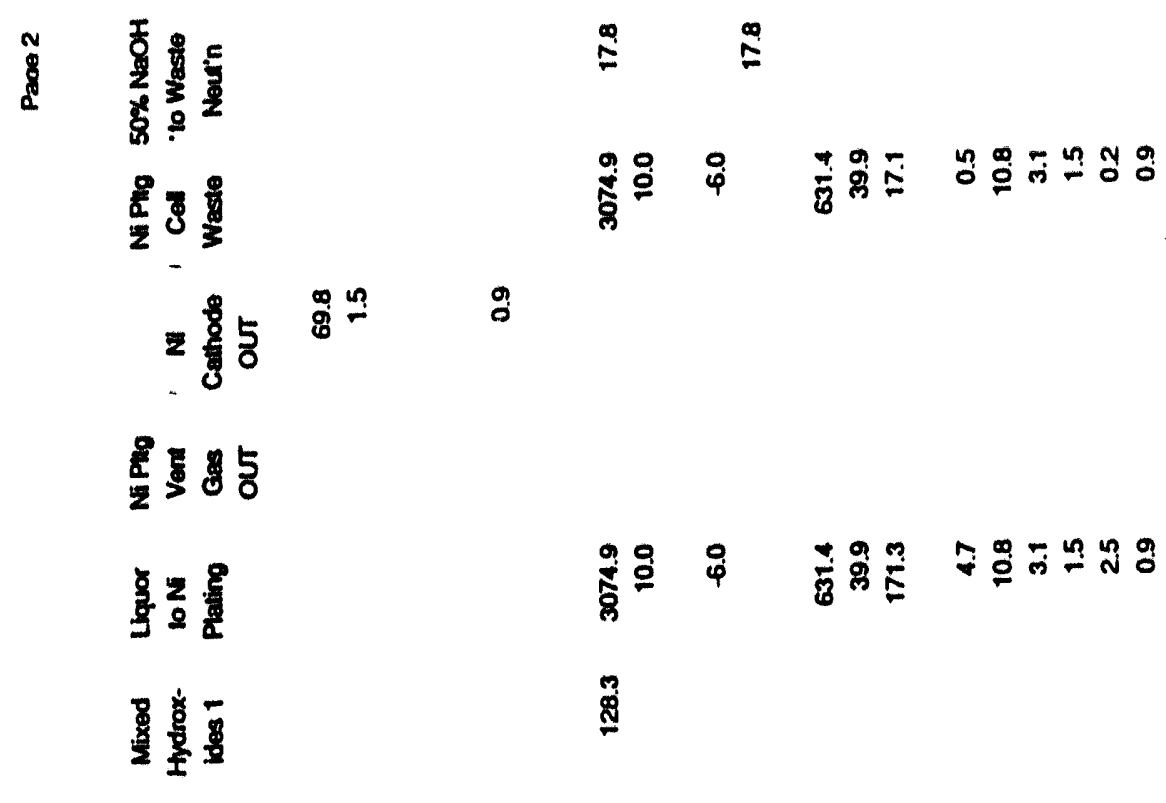

$\stackrel{8}{\circ}$

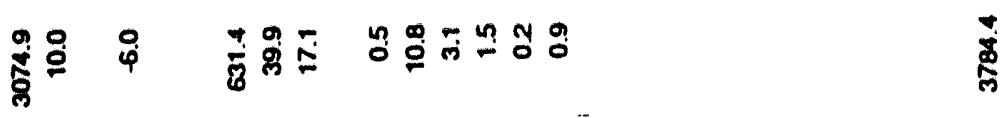

กู

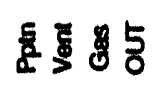

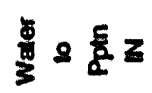

ڤ్

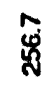

空

$\stackrel{Y}{\ddagger}$

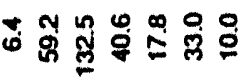

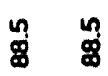

实

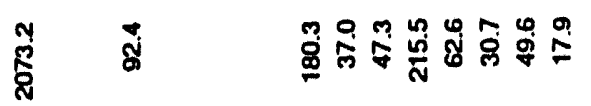

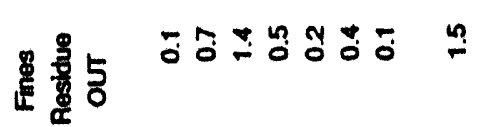

a

क्ष

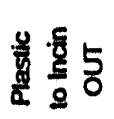

웅

串

ֻृ.

若

3

옹

重要量要

$\stackrel{\infty}{\infty}$

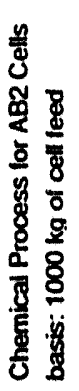

$\stackrel{n}{=}$

$\stackrel{n}{=}$

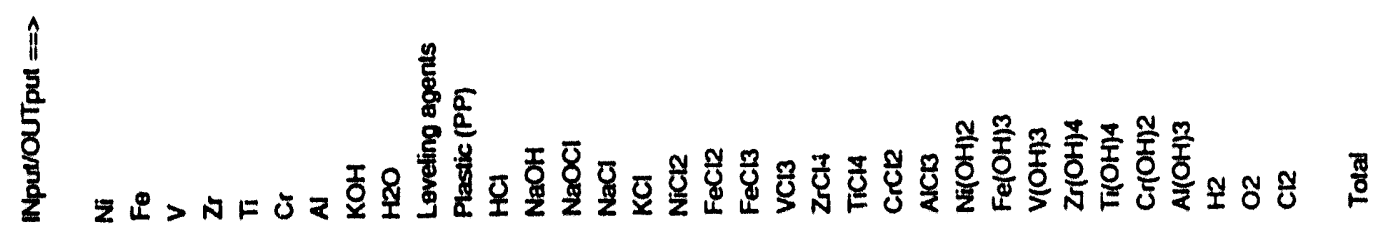




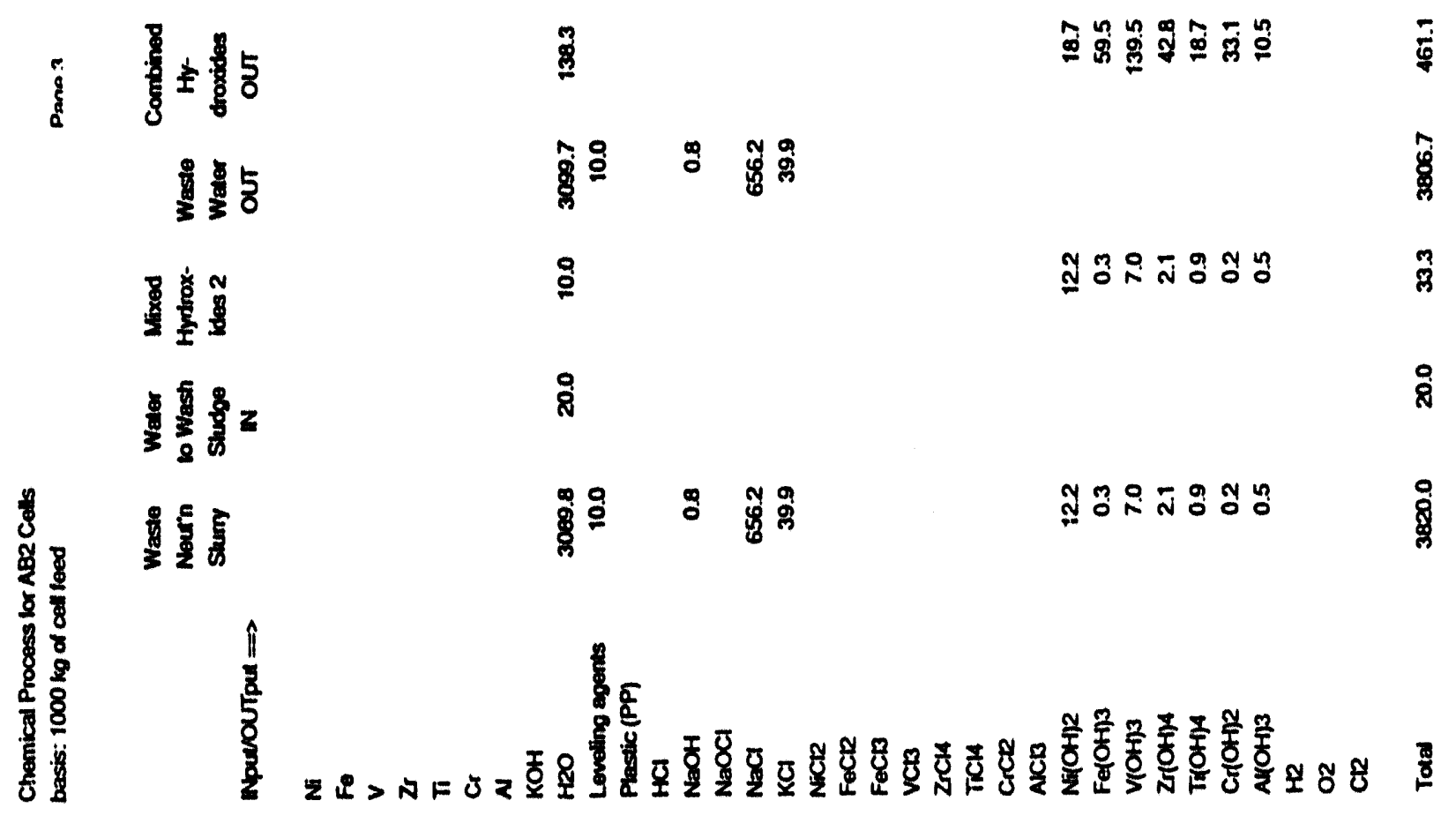




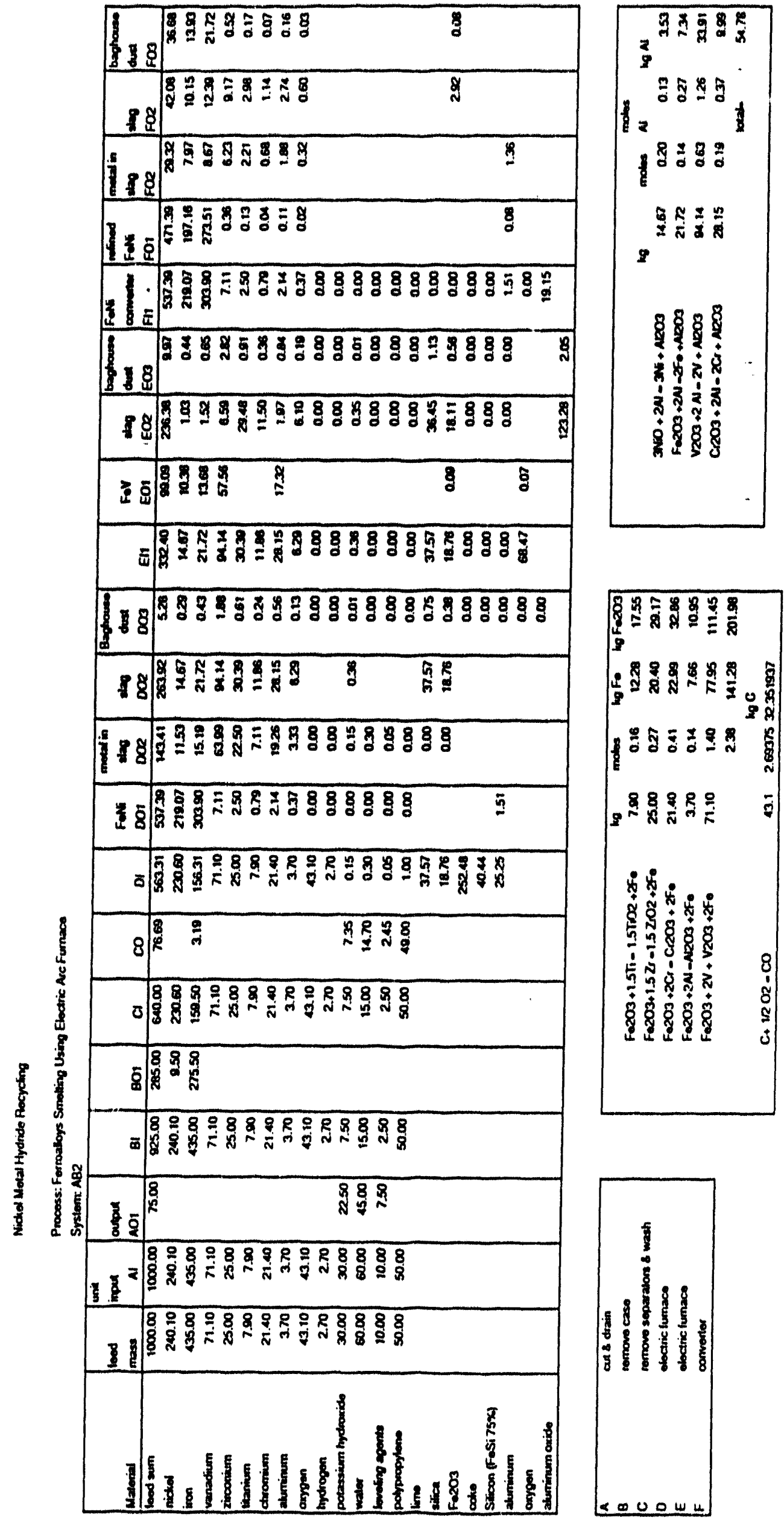




$$
\begin{aligned}
& 15 \\
& =1 \\
& \text { \& } 18= \pm= \\
& \log ^{2}=2
\end{aligned}
$$

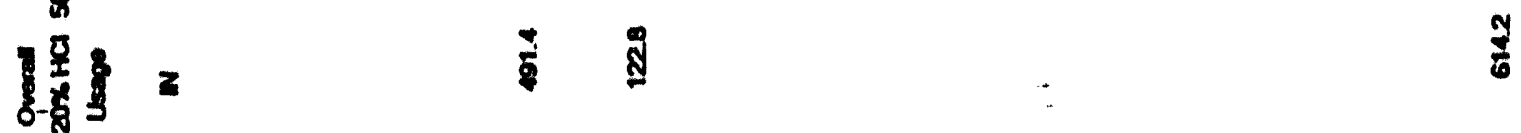

$$
\begin{aligned}
& \text { I2 }
\end{aligned}
$$

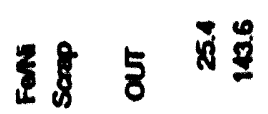

$$
\begin{aligned}
& 1 \text { 重 } \\
& 2250
\end{aligned}
$$

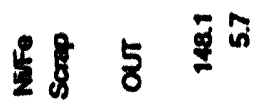

$$
\begin{aligned}
& 218 \\
& 2 \text { ํํำ }
\end{aligned}
$$

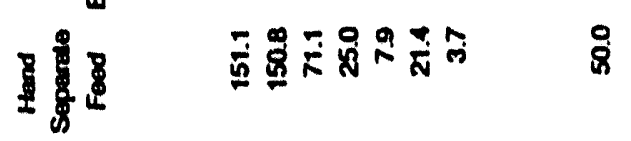

$$
\begin{aligned}
& \text { รั ธั } \\
& \text { ํำ } \\
& \text { 옹응 }
\end{aligned}
$$

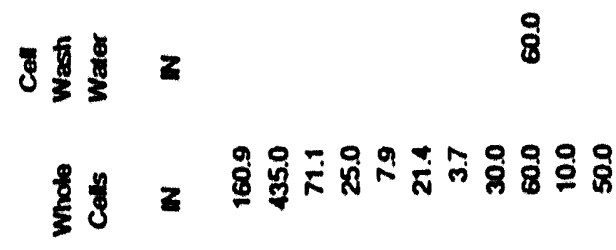




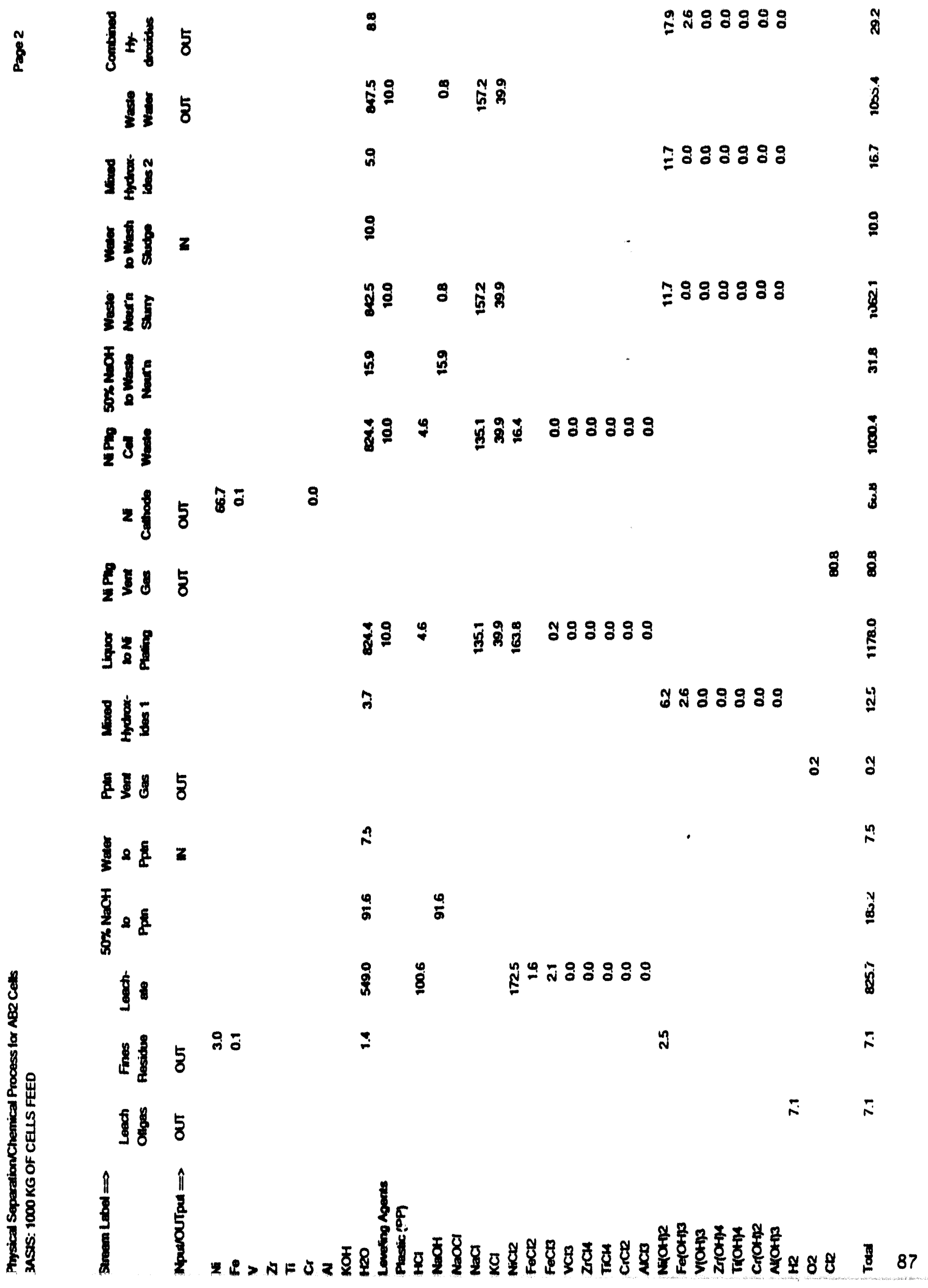




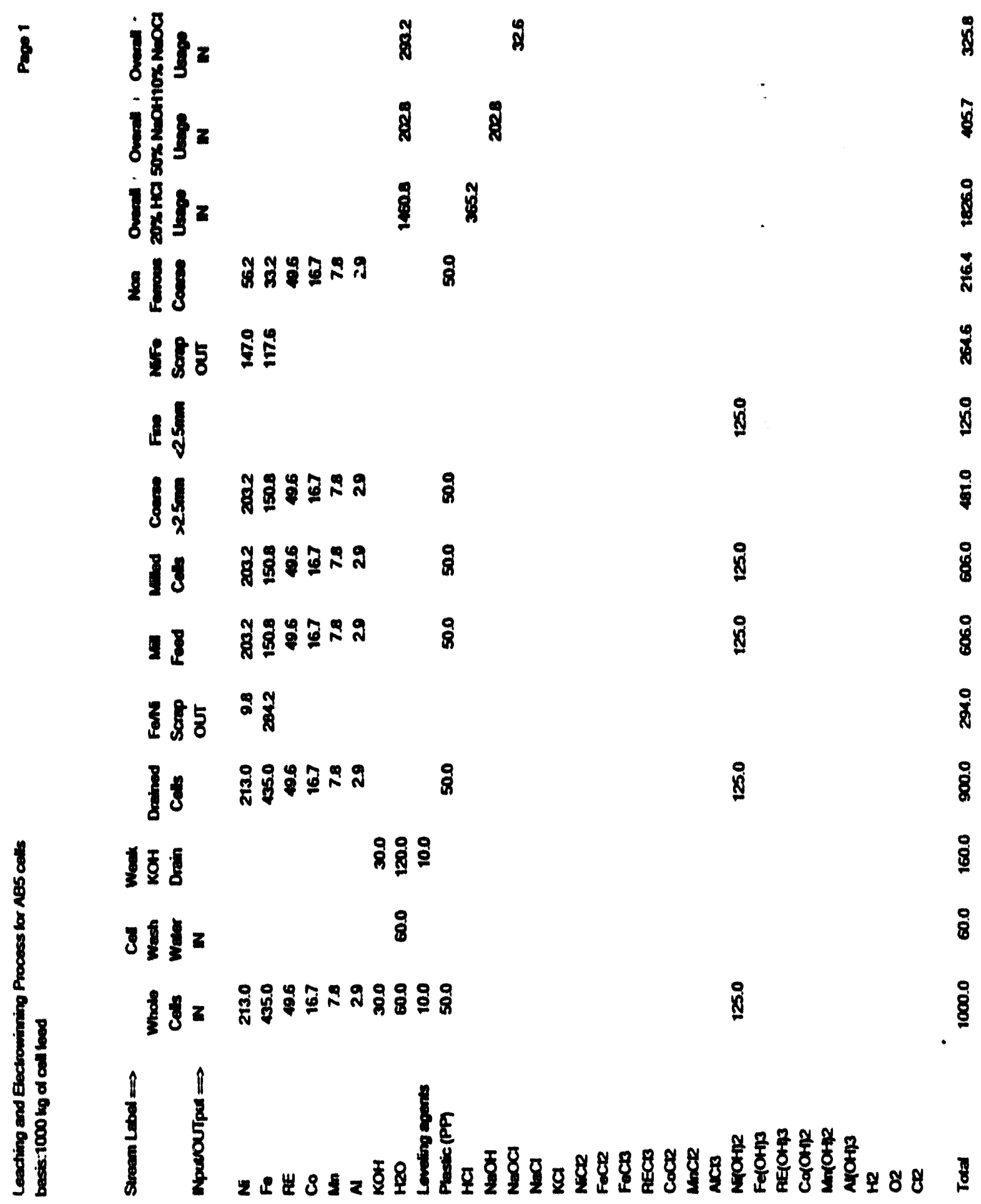




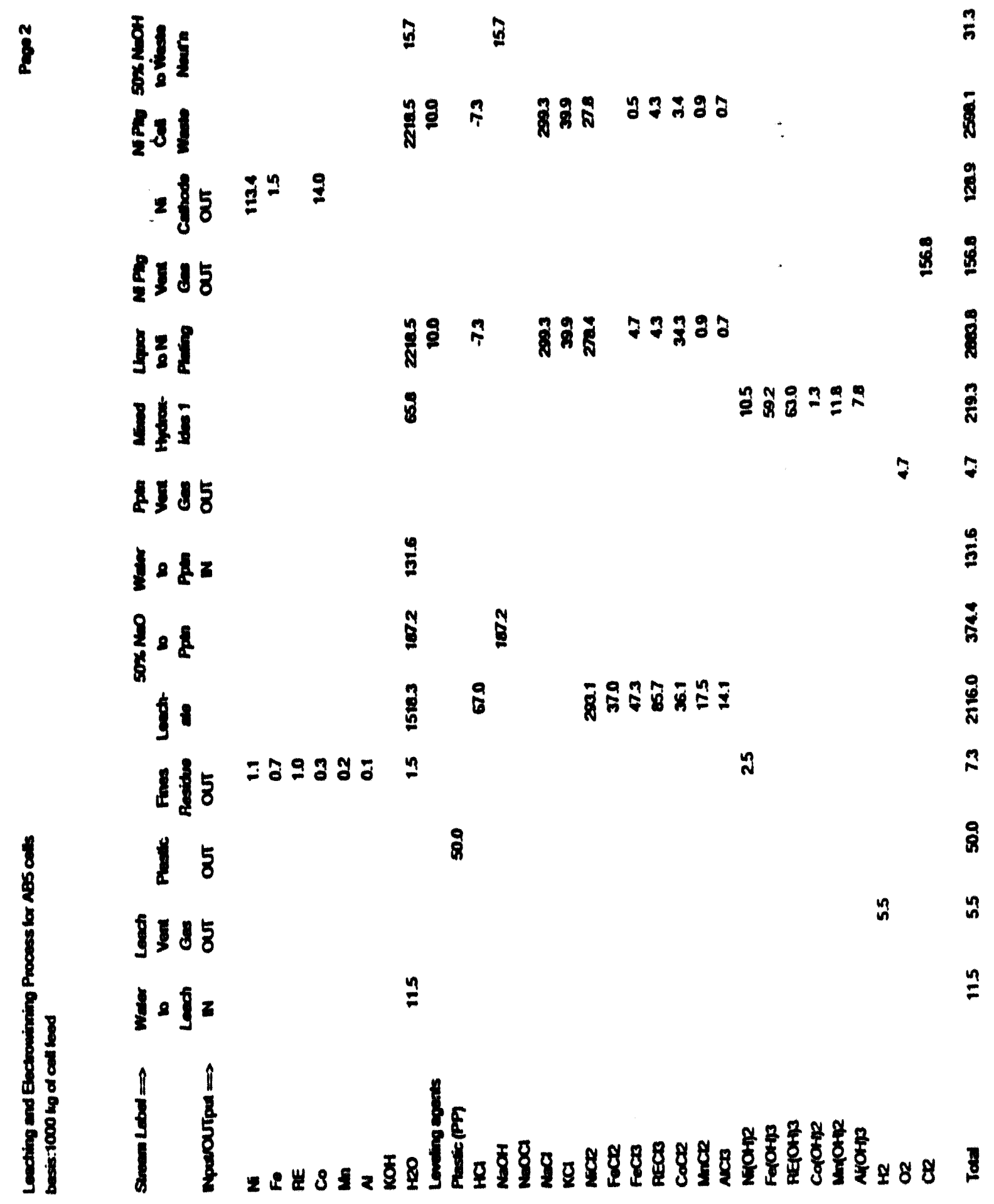


i

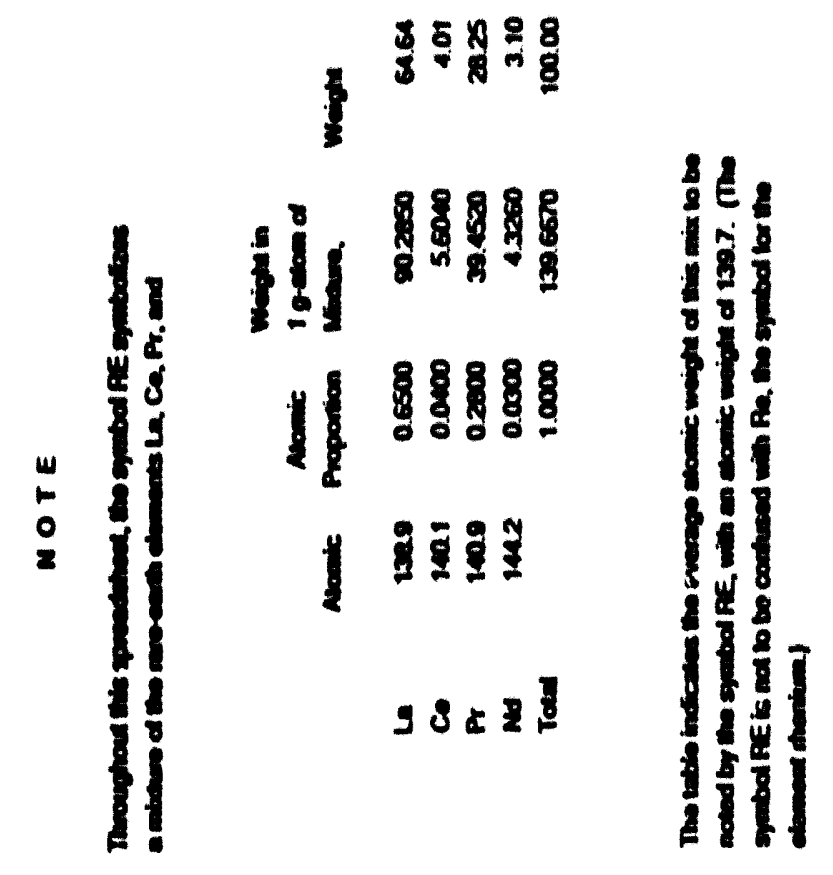

|ำ|

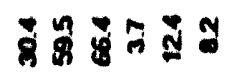

$\frac{9}{5}$

115

ูํ응 ำ ํํำ

$\frac{8}{8}$

8 8

$\underline{5}$

옹ำำำำ

8

$1 \frac{1}{2} 8$

ก

พี

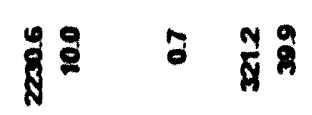

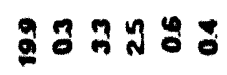

III

$\frac{1}{8} \cdot \frac{\hat{8}}{8}$

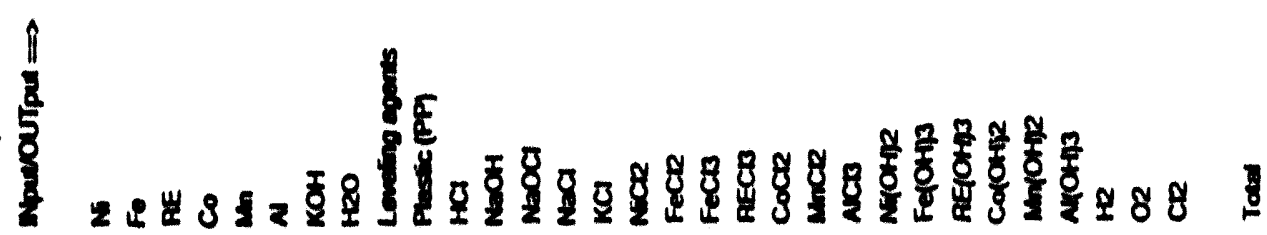




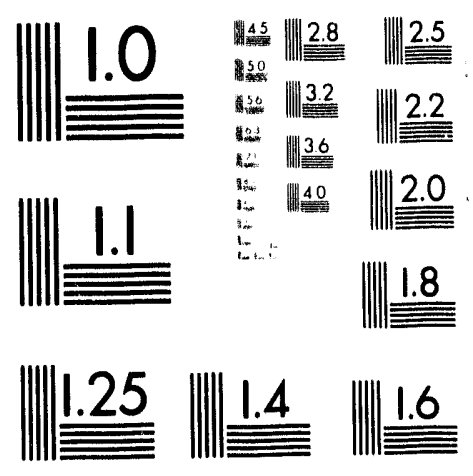



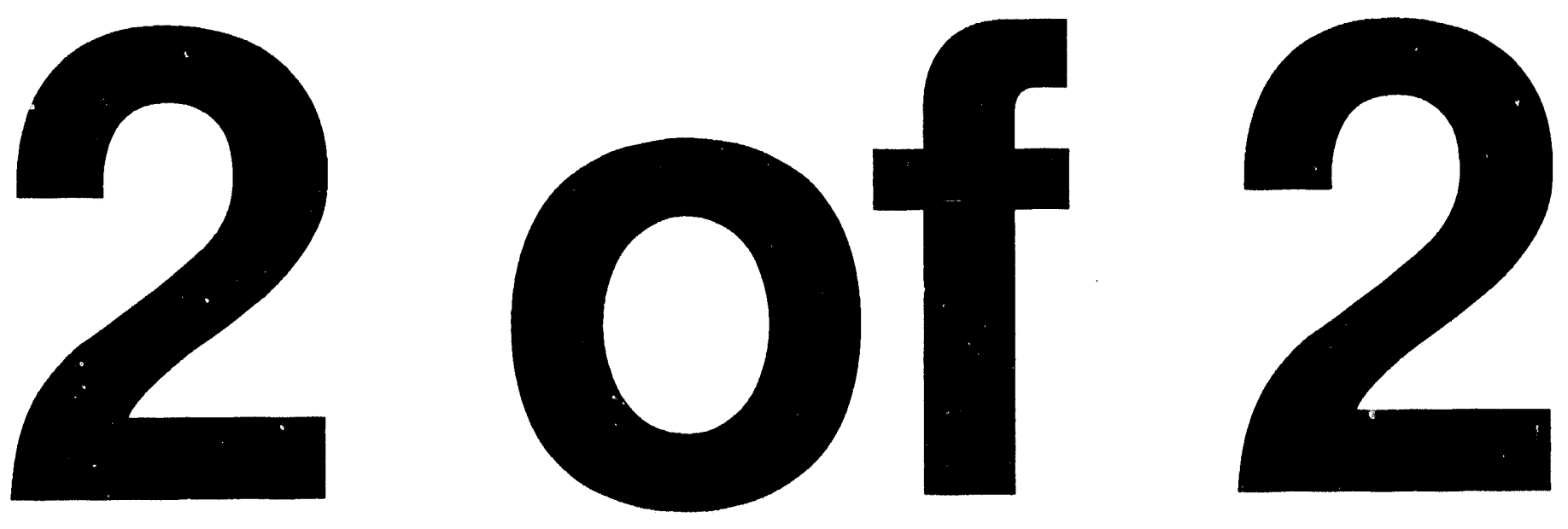


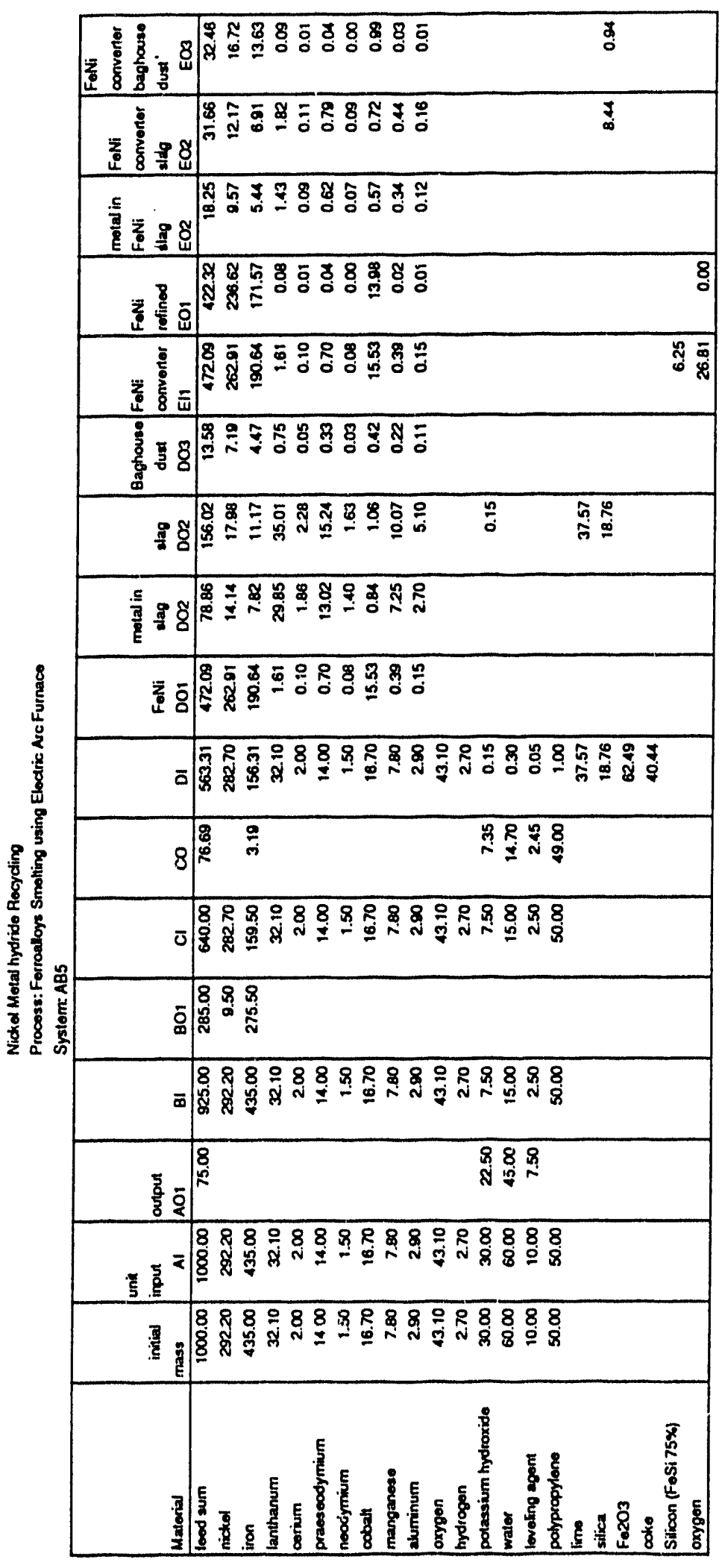
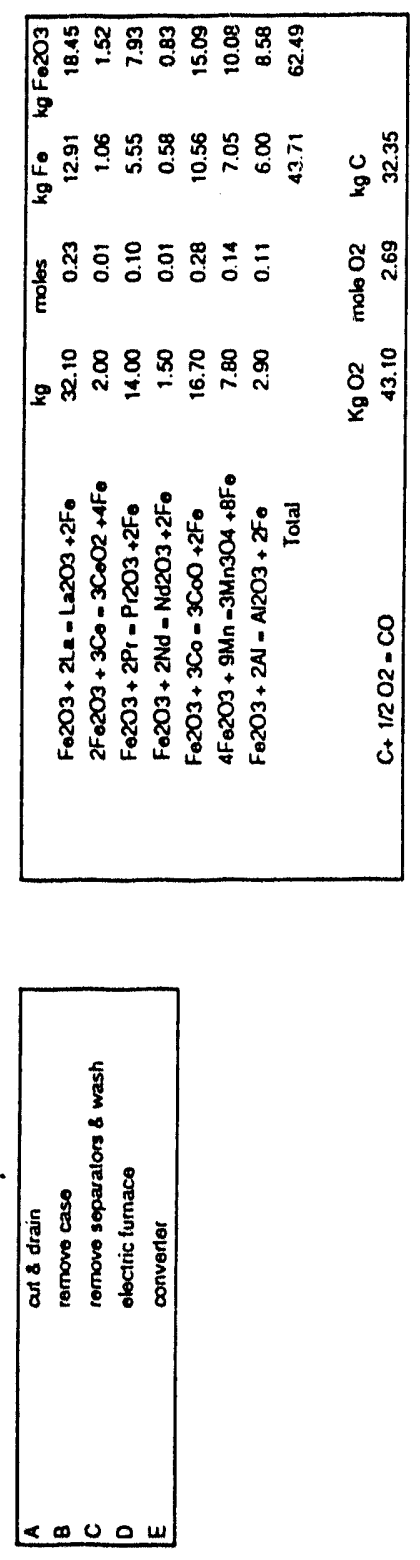


$$
\begin{aligned}
& \text { 善 }
\end{aligned}
$$

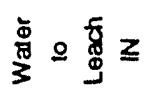

$$
\begin{aligned}
& \cong
\end{aligned}
$$

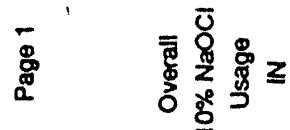

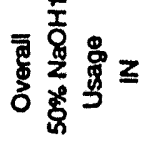

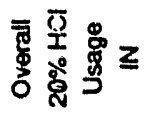

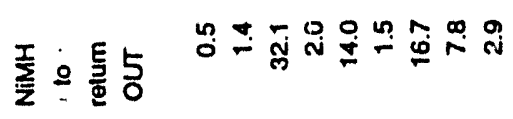

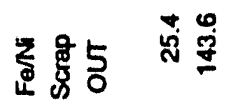

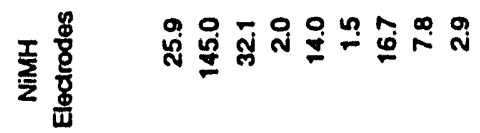

$$
\begin{aligned}
& \text { z噇 可 }
\end{aligned}
$$

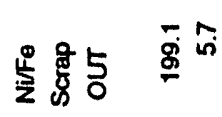

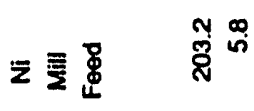

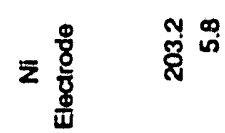

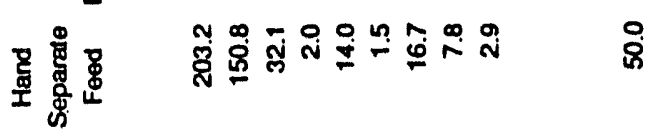

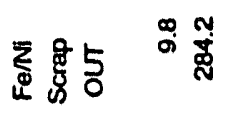

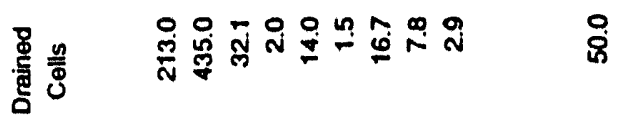

$$
\begin{aligned}
& \stackrel{\circ}{\stackrel{0}{0}} \\
& \text { ํㅗำ } \\
& \text { 옹 } \\
& \text { 蒫 } \\
& \stackrel{\circ}{\stackrel{8}{8}} \\
& \text { 울울응 }
\end{aligned}
$$

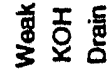

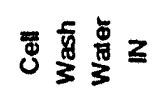

$$
\begin{aligned}
& \text { \& }
\end{aligned}
$$

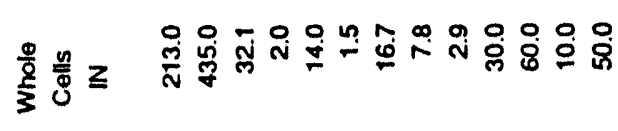

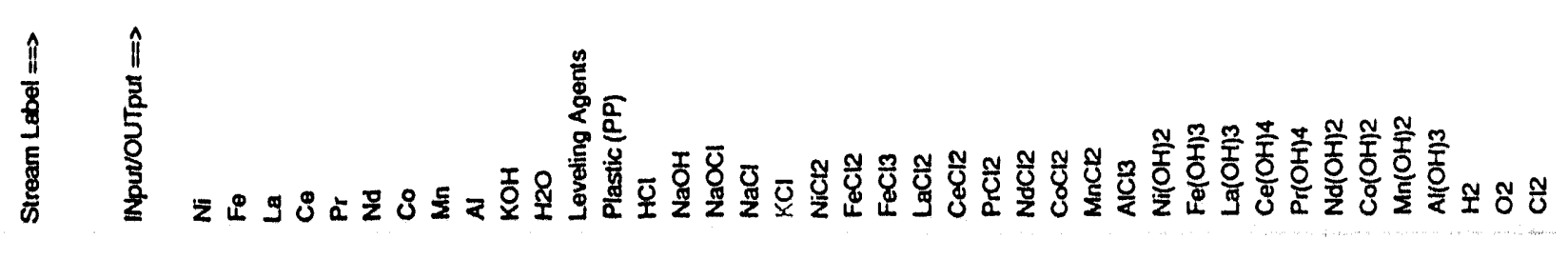




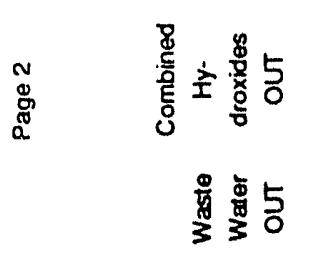

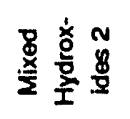

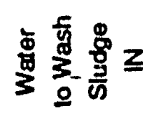

異塞喜

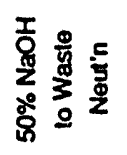

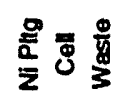

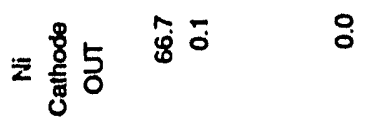

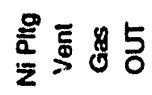

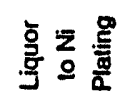

娄旁要

돌

혼 을

空

产旁

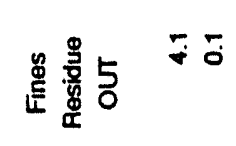

善器要 $\underset{\infty}{\infty}$

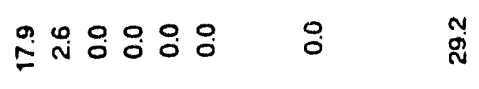

영영영용 응

$\stackrel{\circ}{\circ}$

틍옹응영영 웅

量

$\therefore$

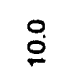

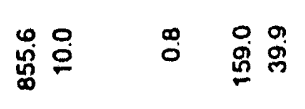

용

品 量

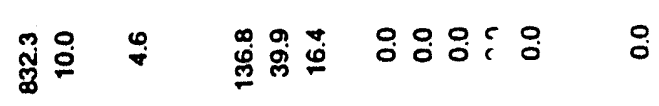

享

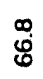

๑ั:

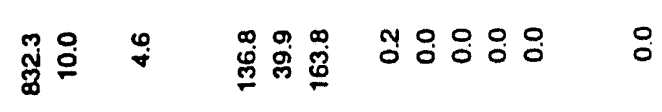

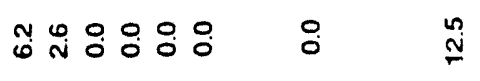

$\approx$ ะ

$\stackrel{2}{2}$

ฐू

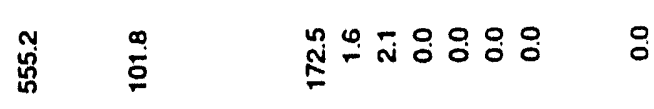

$\cong$

$\stackrel{2}{\sim}$

స్

is

$\stackrel{n}{\sim}$

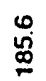

$\overline{\check{\infty}}$

$\infty$

요 is 


\begin{tabular}{|c|c|c|c|}
\hline $\begin{array}{l}\text { Document Control } \\
\text { Page }\end{array}$ & $\begin{array}{l}\text { 1. NREL Report No. } \\
\text { NREL-TP-463-6153 }\end{array}$ & $\begin{array}{l}\text { 2. NTIS Accession No. } \\
\text { DE } 94000268\end{array}$ & 3. Recipient's Accession No. \\
\hline \multirow{2}{*}{\multicolumn{3}{|c|}{$\begin{array}{l}\text { 4. Title and Subtitle } \\
\text { Feasibility Study for the Recycling of Nickel Metal Fydride Electric } \\
\text { Vehicle Batteries }\end{array}$}} & $\begin{array}{c}\text { Publícation Date } \\
\text { January } 1994 \\
\end{array}$ \\
\hline & & & 6. \\
\hline \multicolumn{3}{|c|}{$\begin{array}{l}\text { 7. Author(s) } \\
\text { J.C. Sabatini, E.L. Field, I-C. Wu, M.R. Cox, B.M. Barnett, J.T. Coleman }\end{array}$} & 8. Performing Organization Rept. No. \\
\hline \multirow{2}{*}{\multicolumn{3}{|c|}{$\begin{array}{l}\text { 9. Performing Organization Name and Address } \\
\text { Arthur D. Little, Inc. } \\
\text { Acorn Park } \\
\text { Cambridge, Massachusetts } \quad 02140-2390\end{array}$}} & $\begin{array}{l}\text { 10. Project/Task/Work Unit No. } \\
\text { AS } 115440\end{array}$ \\
\hline & & & $\begin{array}{l}\text { 11. Contract (C) or Grant (G) No. } \\
\text { (C) } \\
\text { (G) }\end{array}$ \\
\hline \multirow{2}{*}{\multicolumn{3}{|c|}{$\begin{array}{l}\text { 12. Sponsoring Organization Name and Address } \\
\text { National Renewable Energy Laboratory } \\
1617 \text { Cole Boulevard } \\
\text { Golden, Colorado } 80401-3393\end{array}$}} & $\begin{array}{l}\text { 13. Type of Report \& Period Covered } \\
\text { Subcontractor report }\end{array}$ \\
\hline & & & 14. \\
\hline \multicolumn{4}{|l|}{ 15. Supplementary Notes } \\
\hline \multicolumn{4}{|c|}{$\begin{array}{l}\text { 16. Abstract (Limit: } 200 \text { words) } \\
\text { This feasibility study examined three possible recycling processes for two compositions }\left(\mathrm{AB}_{2} \text { and } \mathrm{AB}_{5}\right) \text { of nickel } \\
\text { metal hydride electric vehicle batteries to determine possible routes for recovering baltery materials. Analysts } \\
\text { examined the processes, estimated the costs for capital equipment and operation, and estimated the value of the } \\
\text { reciaimed material. They examined the following three processes: (1) a chemical process that leached battery } \\
\text { powders using hydrochloric acid, (2) a pyrometallurical process, and (3) a physical separation/chemical process. } \\
\text { The economic analysis revealed that the physical separation/chemical process generated the most revenue. }\end{array}$} \\
\hline \multirow{2}{*}{\multicolumn{4}{|c|}{$\begin{array}{l}\text { 17. Document Analysis } \\
\text { a. Descriptors } \\
\text { recycling; nickel metal hydride batteries; electric vehicle batteries } \\
\text { b. Identifiers/Open-Ended Terms }\end{array}$}} \\
\hline & & & \\
\hline \multirow{2}{*}{\multicolumn{3}{|c|}{$\begin{array}{l}\text { 18. Availability Statement } \\
\text { National Technical Information Service } \\
\text { U.S. Department of Cornmerce } \\
\text { 5285 Port Royal Road } \\
\text { Springfield, VA } 22161\end{array}$}} & $\begin{array}{l}\text { 19. No. of Pages } \\
100\end{array}$ \\
\hline & & & $\begin{array}{l}\text { 20. Price } \\
\text { A05 }\end{array}$ \\
\hline
\end{tabular}

Form No. 0069E (6-30-87) 

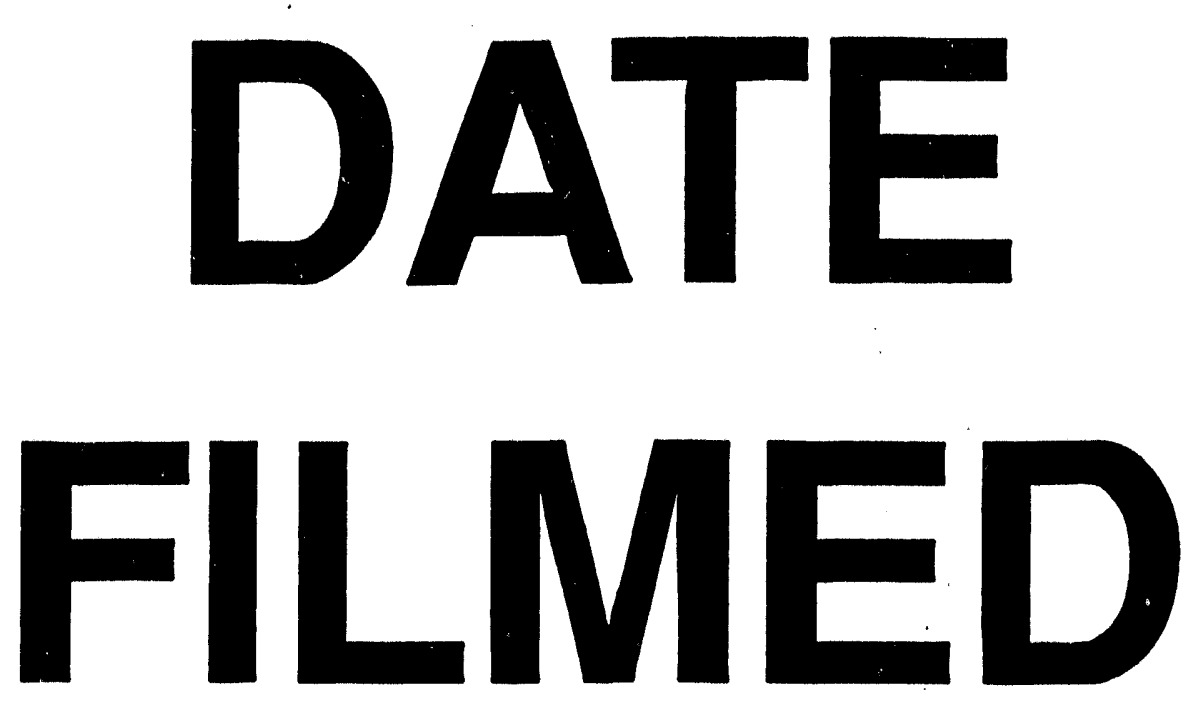

$3 / 17 / 94$
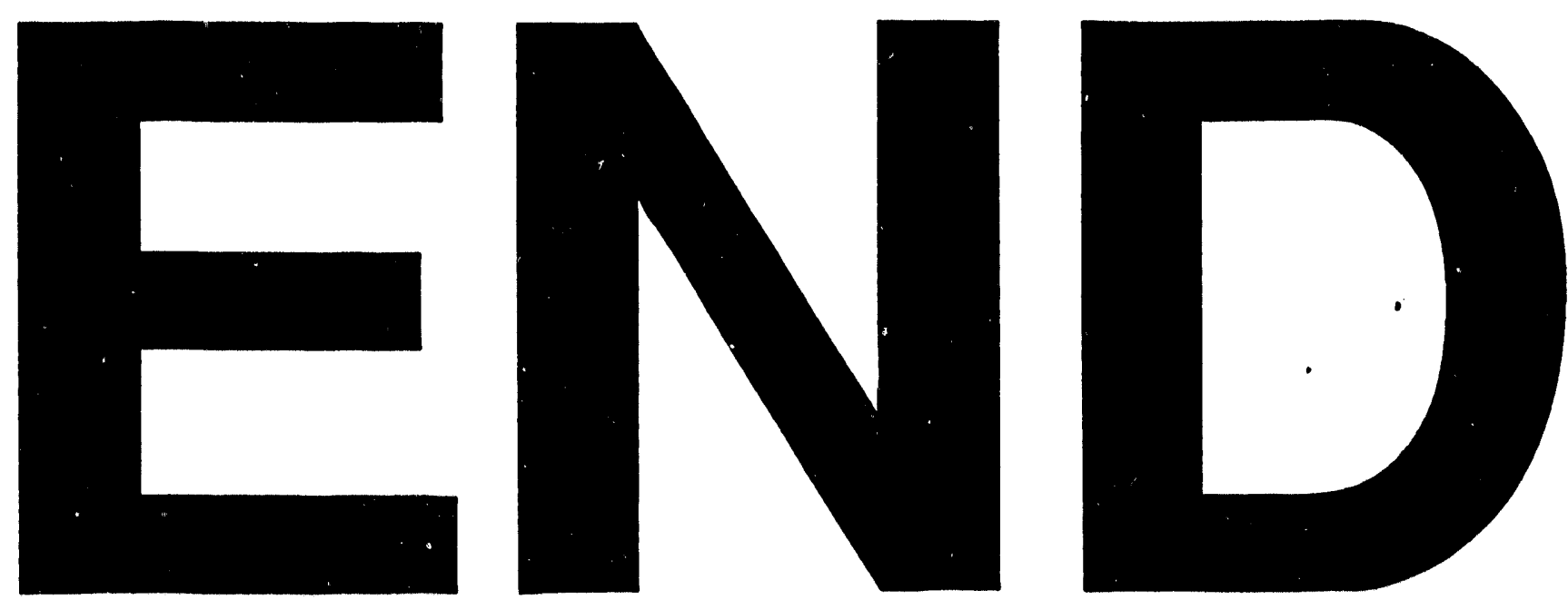
